



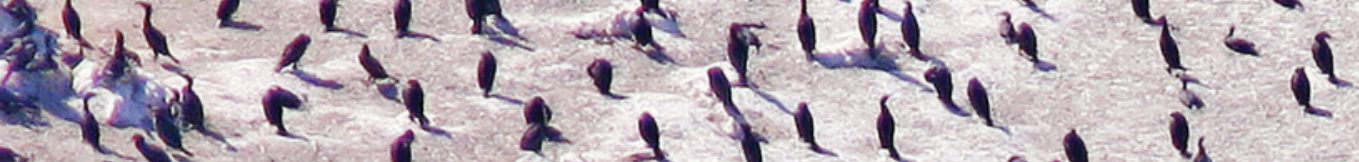
$=z^{2} c^{2}+t^{2} x^{k} z^{-1}$

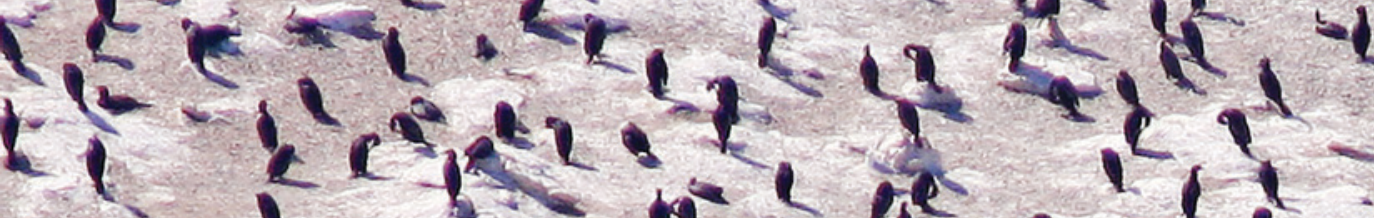
te $x^{2} \cdot 1$




1. L b ta $41^{2} 1$ $\rightarrow \Rightarrow 5=3 t^{-}$

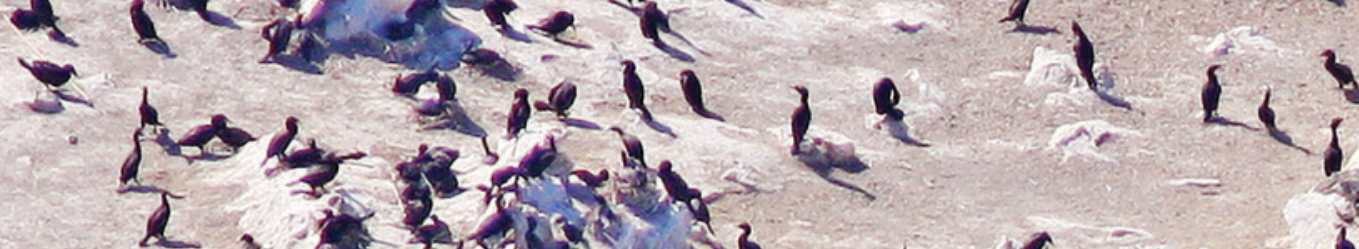



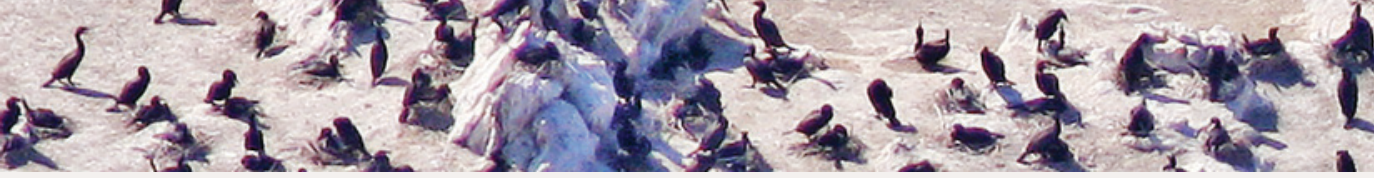

Vol. 51, No. 4, 2020 


\section{Western Specialty: Plumbeous and Cassin's Vireos}
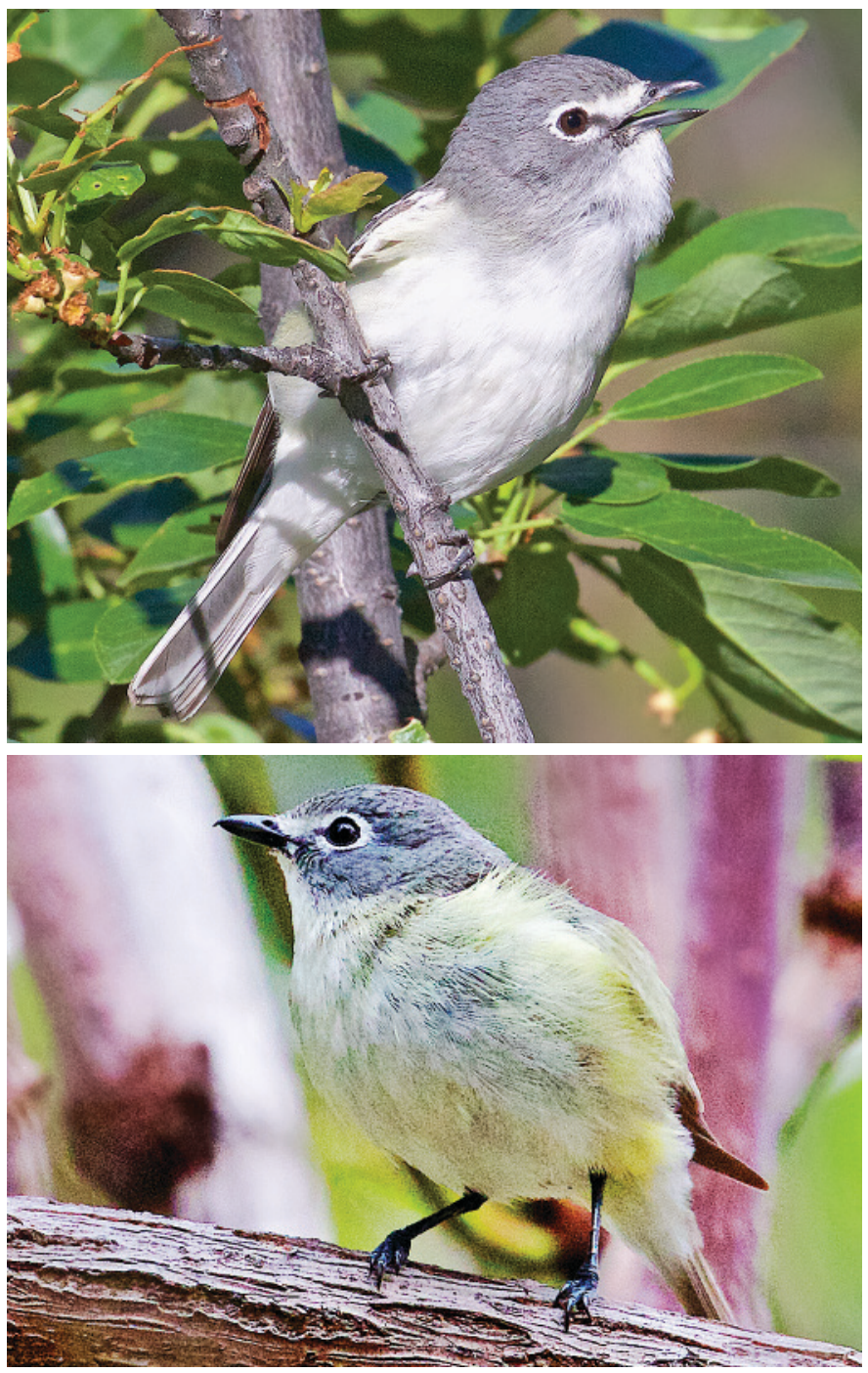

Photos by (C) Ed Harper of Carmichael, California:

Top: Plumbeous Vireo (Vireo plumbeus) near Pocatello, Idaho, 29 May 2015. Bottom: Cassin's Vireo (Vireo cassinii), El Dorado National Forest, El Dorado Co., California 25 May 2016.

More than two decades after the American Ornithologists' Union split the Solitary Vireo complex into three species (Auk 114:542-552, 1997), some uncertainty about the exact limits of the breeding ranges of the Cassin's and Plumbeous Vireos remains, likely because some Cassin's in worn, faded plumage are difficult to distinguish. In this issue, Ed Pandolfino and Chris Ray compare the two species' songs and show that, with good recordings, most birds can be identified to species by song. 


\section{Volume 51, Number 4, 2020}

Distribution and Abundance of Double-crested Cormorants

Nesting in the Interior of California, 2009-2012

W. David Shuford, Kathy C. Molina, John P. Kelly, T. Emiko Condeso,

Daniel S. Cooper, and Dennis Jongsomjit

Comparison of the Songs of Cassin's and Plumbeous Vireos

Edward R. Pandolfino and Chris Ray

Nesting Biology of Urban Cooper's Hawks in Alameda County, California

Ralph V. Pericoli, Emma L. Karsten, Allen M. Fish,

and Christopher W. Briggs

\section{NOTES}

First Evidence of Breeding of the Red-necked Grebe in California Kenneth P. Able

Apparent Use of a Rock Crevice as a Nocturnal Roost by a

Ruby-crowned Kinglet Emilie Strauss and David L. Swanson

Unusual Record of Bonaparte's Gull in the Sierra San Pedro Mártir, Baja

California Gorgonio Ruiz-Campos, Gonzalo de León-Girón, Hiram

Rafael Moreno-Higareda, and Armando Jesús Contreras-Balderas

Book Reviews Clayton Anderson and David Koeppel

Featured Photo: Sanderling Scavenging Crab Fragments from a Foraging

Western Gull Floyd E. Hayes and Vivek Khanzode

Thanks to Western Birds' Reviewers and Associate Editors

Index Daniel D. Gibson

Front cover photo by (C) W. D. Shuford of Petaluma, California: Aerial view of the Double-crested Cormorant (Phalacrocorax auritus) colony at Mullet Island, Salton Sea, 15 February 2012. Though the largest inland cormorant colony in California from 1997 to 1999 and 2009 to 2013, reaching 6594 nests in 2012, it has been abandoned since 2014, as the falling level of the Salton Sea joined the island to the mainland.

Back cover "Featured Photos" by (C) Vivek Khanzode of Sunnyvale, California: a Sanderling (Calidris alba) watching a Western Gull (Larus occidentalis) eating its fill of a crab (Pugettia producta), then scavenging the remains after the gull abandoned them - the first evidence of a Sanderling aware that it can capitalize on a predator's behavior.

Western Birds solicits papers that are both useful to and understandable by amateur field ornithologists and also contribute significantly to scientific literature. The journal welcomes contributions from both professionals and amateurs. Appropriate topics include distribution, migration, status, identification, geographic variation, conservation, behavior, ecology, population dynamics, habitat requirements, the effects of pollution, and techniques for censusing, sound recording, and photographing birds in the field. Papers of general interest will be considered regardless of their geographic origin, but particularly desired are reports of studies done in or bearing on North America west of the 100th meridian, including Alaska and Hawaii, northwestern Mexico, and the northeastern Pacific Ocean.

Send manuscripts to Daniel D. Gibson, P. O. Box 155, Ester, AK 99725; avesalaska@ gmail.com. For matters of style consult the Suggestions to Contributors to Western Birds (at https://westernfieldornithologists.org/publications/journal). 


\section{WESTERN BIRDS}

Volume 51, Number 4, 2020

\section{DISTRIBUTION AND ABUNDANCE OF DOUBLE- CRESTED CORMORANTS NESTING IN THE INTERIOR OF CALIFORNIA, 2009-2012*}

W. DAVID SHUFORD, Point Blue Conservation Science, 3820 Cypress Dr., \#11, Petaluma, California 94954; dshuford-RA@pointblue.org (current address: 1040 Helen Ct., Petaluma, California 94954)

KATHY C. MOLINA, Section of Ornithology, Natural History Museum of Los Angeles County, 900 Exposition Blvd., Los Angeles, California 90007

JOHN P. KELLY (current address: 1424 Santa Fe Drive, Encinitas, California 92024) and T. EMIKO CONDESO, Audubon Canyon Ranch, Cypress Grove Research Center, P. O. Box 808, Marshall, California 94940

DANIEL S. COOPER, Cooper Ecological Monitoring, Inc., 255 Satinwood Ave., Oak Park, California 91377

DENNIS JONGSOMJIT, Point Blue Conservation Science, 3820 Cypress Dr., \#11, Petaluma, California 94954

ABSTRACT: As part of an 11-state inventory, we censused the Double-crested Cormorant (Phalacrocorax auritus) in the interior of California from 2009 to 2012, using a combination of aerial, ground, and boat surveys. An estimated 8791 pairs breeding in the interior of the state in 2009-2012 exceeded the 7170 pairs estimated in 1998-1999. In both periods, cormorants were breeding in 9 of 11 ecoregions, but three-fourths were at one site-Mullet Island at the Salton Sea in the Sonoran Desert ecoregion (abandoned in 2014). The ecoregions with the next highest proportions were the Sacramento Valley, San Joaquin Valley, and Modoc Plateau. The apparent increase in numbers and colony sites since 1999-consistent with the pattern through much of western North America-reflects the (short-lived) increase in numbers at the Salton Sea, an increasing number of colonies and breeding pairs in the Central Valley, and slightly better coverage on the recent surveys. Because of practical survey constraints and limited data to date, evidence of change in numbers of Doublecrested Cormorants breeding in the interior of California between 1998-1999 and 2009-2012 is inconclusive. Plans for monitoring will need to take into account the effects of substantial annual variation in numbers, which may be associated with large fluctuations in cormorants' prey base, short-term cycles of drought and flood, shifts of nesting cormorants into or out of the interior of California, and the expectation of greater environmental fluctuations with continuing climate change. The factors most likely to limit the number of cormorants breeding in the interior of the

\footnotetext{
${ }^{*}$ This paper is dedicated to the memory of the late Harry R. Carter, whose outstanding work on coastal seabirds and, particularly, his generous support, mentorship, and humanity inspired Shuford's studies of colonial waterbirds in the interior of California.
} 
state are habitat loss or alteration (particularly from reallocation of water for human needs), disease, human disturbance, and the long-term effects of climate change.

In North America, the Double-crested Cormorant (Phalacrocorax auritus) is currently widespread and often perceived as overabundant when viewed through the lens of fisheries and aquaculture conflicts. Yet a review of historical and current records indicates that the species was likely more abundant during initial European settlement than it is today, suggesting the perception of current overabundance rests on socio-political rather than biological or ecological factors. Continent-wide, cormorant numbers had sharply declined by the late 1800s and early 1900s, partially recovered between the 1920s and 1940s, declined sharply again from the late 1940s to 1970s, and rebounded again from the late 1970s through the end of the 20th century (Wires and Cuthbert 2006).

Along the Pacific coast of western North America, from southern British Columbia to northwestern Mexico and in the adjacent interior states, the Double-crested Cormorant was far more abundant in the 19th century than it is today, but by the late 1800s and early 1900s it had declined substantially (Wires and Cuthbert 2006). Populations in western North America (at least exclusive of Alaska and northwestern Mexico) subsequently increased from the mid-1900s to circa 2009, though at a rate lower than the exponential expansion documented east of the continental divide (Carter et al. 1995, Adkins et al. 2014). From 2014 to 2018 numbers in the region were relatively stable (USFWS 2019). Despite these broad patterns, trends in the West have varied by country, subregion, and state or province, and in the interior status and trends are less certain, owing to inadequate surveys.

Initiatives to promote the conservation of waterbirds throughout North America recognize the importance of inventorying and monitoring for determining conservation status, detecting population trends, assessing habitat health, and evaluating whether management and environmental change are affecting waterbirds (Kushlan et al. 2002). But to date a paucity of adequate data on the sizes and trends of waterbird populations has hampered efforts to conserve these birds in California (Shuford 2014b, Shuford and Dybala 2017) and the interior West (Seto 2008). Although there are extensive data on colonies of species such as the Double-crested Cormorant along the entire California coast from periodic broad-scale inventories (Sowls et al. 1980, Carter et al. 1992, Capitolo et al. 2004) and, since 1993, annual monitoring with aerial photographs (see Capitolo et al. 2019), there is much less information on this cormorant's populations in the interior of California and other western states.

To help fulfill these needs, from 2009 to 2012 the U.S. Fish and Wildlife Service coordinated the Western Colonial Waterbird Survey, a broad-scale inventory of 19 species of colonial waterbirds in 11 western states (www. fws.gov/mountain-prairie/migbirds/species/birds/western_colonial/index. html). Its goals were to document the species composition, size, and location of colonies; estimate minimum regional population sizes for each breeding species; produce an atlas of colonies; and establish a baseline for the development of a long-term monitoring program.

To ensure adequate coverage of the vast expanse of the West, regional 
experts organized and implemented the surveys at the state level. In California, Point Blue Conservation Science and its collaborators coordinated surveys of 15 primary species of colonial waterbirds (Shuford 2014a). Results of those surveys from 2009 to 2012, and comparisons to prior surveys, have been published for three species of terns, two of gulls (Shuford et al. 2016, Doster and Shuford 2018), and five of ardeids surveyed statewide (Shuford et al. 2020). Here we report on the distribution, number of colonies, and number of pairs of Double-crested Cormorants nesting in the interior of California from 2009 to 2012, and compare our results to those of surveys in 1998 and 1999 (Shuford 2010). We also compare the trends of the populations in the interior with those along the coast, interpret results on the basis of environmental conditions and prey dynamics, discuss current and future threats to cormorants breeding in the interior of California, and consider how recent and future surveys can aid in development of a strategy for monitoring colonial waterbirds throughout the western United States.

\section{STUDY AREA AND METHODS}

In organizing statewide surveys, we based the timing and extent of field work on a combination of extensive information gathered on the locations of historical and recent colonies, broad personal knowledge of wetlands and other potential foraging and nesting habitats since the 1980s, and discussions with a large network of collaborators developed over the years and expanded during the 2009-2012 surveys. These efforts were greatly enhanced by biologists who shared survey data from local or regional monitoring projects.

Because it was not feasible to survey all 15 target species statewide in the same year under the same environmental conditions, we surveyed the Double-crested Cormorant along with other species of colonial waterbirds by region. Consequently, surveys for the cormorant took three years and included only the interior of California (Shuford 2014a). To avoid or minimize overlap with efforts focused on coastal seabirds, our "interior" survey area for the cormorant included all of the state except for colonies on offshore islands or rocks, coastal bluffs, within estuaries, or otherwise within $10 \mathrm{~km}$ of the ocean or estuarine shoreline. We excluded all of the San Francisco Bay estuary west of the Carquinez Strait at Interstate 80.

We surveyed for breeding colonies of the Double-crested Cormorant in northeastern California in 2009; in the Sacramento Valley, Sacramento-San Joaquin River delta, and the northern and central coastal slope in 2011; and the San Joaquin Valley, coastal slope of southern California, the Salton Sea and Imperial Valley, and the Owens, Mojave, and lower Colorado River valleys in 2012. In 2012, we also surveyed the very limited potential habitat for nesting cormorants in the Klamath River country of northwestern California in Shasta, (mainly) western Siskiyou, and northern Humboldt counties. Descriptions of these study regions and the survey methods used in each are detailed in Shuford et al. (2020); the methods and areas surveyed were very similar to those used in a comparable statewide survey for cormorants in the interior from 1997 to 1999 (Shuford 2010).

Observers generally followed the protocols of the Western Colonial Waterbird Survey (Jones 2008), whether from the ground, aircraft (visually 
or with photographs), or boat. Methods varied by species, colony site, and region, depending on the species' nesting habits and local conditions, such as variation in nest substrates, proximity of other nesting species, and accessibility of colony sites (Shuford 2014a, Shuford et al. 2020). Aerial surveys were particularly valuable for photographing some large or remote cormorant colonies and for visually covering large areas, such as the Central Valley, that would have been impossible to survey adequately by other methods alone.

At each colony, observers tried to count or estimate the number of active nests or nesting pairs by species. Active nests were defined as those that, at the time of the survey, were attended by an adult(s), held eggs or young, or showed signs of occupancy (e.g., extensive guano) earlier in the current breeding season. As much as possible, surveys were timed around peak nesting, which varied by species. So, in some cases, follow-up surveys on one or more dates were needed to accommodate colonies with both early- and late-nesting species. Complicating matters further, within colonies of some species, including the Double-crested Cormorant, breeding may be asynchronous. The timing of breeding may vary from year to year and from site to site within a year. This sometimes required multiple surveys at a site to ensure a count close to or at the peak of nesting. Hence, at some multi-species colonies, we counted cormorants more frequently than if we had been surveying just for them alone.

To estimate the number of breeding pairs of the Double-crested Cormorant in the interior of California, we summed the regional estimates. This introduced an unknown degree of sampling variation, amplifying uncertainty in the total estimate because we could not gauge how much regional populations varied or shifted over the four years of the study in response to variation in precipitation, prey populations, or other factors.

\section{Comparison with Previous Surveys}

To consider possible change over time, we compared the results for 2009-2012 to comparable data from 1997 to 1999, also recorded regionally Shuford (2010). For the Double-crested Cormorant, however, almost all interior colonies were covered in 1999. For comparisons, we used the 1999 data, augmented by data for a few sites covered in 1998 but not in 1999 (derived from Table 2 in Shuford 2010).

Despite the considerable limits of the data, as described above and in Table 1, we conducted an analysis of variance (ANOVA) to determine if any of the differences between 1998-1999 and 2009-2012 were significant $(P<0.05)$. We designed the ANOVA as a three-way test for differences in abundance between survey periods, among ecoregions, and their interactions, against the random variation among colonies nested within ecoregions.

\section{Climatic Conditions}

Patterns of annual precipitation varied before and through the study but included several years of drought preceding survey years in most regions of the state (Shuford et al. 2020, which see for details of rainfall history by ecoregion). Of particular relevance to the cormorant, our surveys of northeastern and east-central California in 2009 followed 3 years of drought that left some terminal lakes, reservoirs, and wetlands dry or with atypically low 
TABLE 1 Estimated Numbers of Pairs of Double-crested Cormorants at Colonies in the Interior $^{a}$ of California by Ecoregion $^{b}$ and County, 1998-1999 and 2009-2012

\begin{tabular}{|c|c|c|c|c|c|}
\hline Site & $\begin{array}{l}\text { Elevation } \\
(\mathrm{ft})\end{array}$ & Latitude & Longitude & $\begin{array}{c}\text { Estimated } \\
\text { pairs } \\
1998- \\
1999^{c} \\
\end{array}$ & $\begin{array}{c}\text { Estimated } \\
\text { pairs } \\
2009- \\
2012 \\
\end{array}$ \\
\hline \multicolumn{6}{|l|}{ NORTHWESTERN CALIFORNIA } \\
\hline \multicolumn{6}{|l|}{ Lake County } \\
\hline \multicolumn{6}{|l|}{ Clear Lake } \\
\hline Mouth of Holiday Cove & 1333 & 39.0286 & -122.8800 & 25 & 0 \\
\hline Long Tule Point & 1332 & 39.0242 & -122.8586 & 57 & 0 \\
\hline East of Quercus Point & 1332 & 39.0231 & -122.8283 & $175^{d}$ & 0 \\
\hline Slater Island, Anderson Marsh & 1334 & 38.9311 & -122.6319 & 15 & 0 \\
\hline Upper Rodman Slough & 1326 & 39.1366 & -122.9021 & 0 & 53 \\
\hline Indian Valley Reservoir & 1478 & 39.1530 & -122.5360 & 0 & 3 \\
\hline \multicolumn{6}{|l|}{ Sonoma County (part) } \\
\hline Delta Pond & 55 & 38.4467 & -122.8344 & 0 & 27 \\
\hline Laguna de Santa Rosa, Alpha Farms & 75 & 38.3886 & -122.8011 & 59 & 0 \\
\hline \multicolumn{6}{|l|}{ Napa County } \\
\hline Lake Hennessey, Chiles Creek & 355 & 38.4911 & -122.3494 & 0 & 10 \\
\hline Ecoregion total & & & & 331 & 93 \\
\hline \multicolumn{6}{|l|}{ CENTRAL WESTERN CALIFORNIA } \\
\hline \multicolumn{6}{|l|}{ Sonoma County (part) } \\
\hline Petaluma wastewater plant & 14 & 38.2222 & -122.5804 & 6 & 4 \\
\hline \multicolumn{6}{|l|}{ San Benito County } \\
\hline San Felipe Lake & 138 & 36.9817 & -121.4603 & $11^{e}$ & 0 \\
\hline \multicolumn{6}{|l|}{ San Luis Obispo County } \\
\hline Twitchell Reservoir & 750 & 35.0084 & -120.3338 & $-f$ & 30 \\
\hline Ecoregion total & & & & 17 & 34 \\
\hline \multicolumn{6}{|l|}{ SOUTHWESTERN CALIFORNIA } \\
\hline \multicolumn{6}{|l|}{ Los Angeles County ${ }^{g}$} \\
\hline San Gabriel River, Pico Rivera & 154 & 33.9842 & -118.0787 & $\sim 6$ & 0 \\
\hline Sepulveda Basin WA & 690 & 34.1755 & -118.4725 & 0 & 12 \\
\hline Legg Lake & 217 & 34.0347 & -118.0620 & 0 & 30 \\
\hline \multicolumn{6}{|l|}{ Orange County } \\
\hline Orange Co. Water District, Anaheim Lake & 239 & 33.8622 & -117.8457 & 105 & 168 \\
\hline \multicolumn{6}{|l|}{ Riverside County (part) } \\
\hline Prado Basin near dam & 488 & 33.8942 & -117.6434 & $30+$ & 55 \\
\hline Mystic Lake & 1428 & 33.8808 & -117.0792 & 64 & 0 \\
\hline \multicolumn{6}{|l|}{ San Diego County } \\
\hline Sweetwater Reservoir & 237 & 32.7076 & -116.9761 & 28 & 0 \\
\hline Ecoregion total & & & & 233 & 265 \\
\hline \multicolumn{6}{|l|}{ SACRAMENTO VALLEY } \\
\hline \multicolumn{6}{|l|}{ Glenn County } \\
\hline Howard Slough, at Butte Creek & 62 & 39.3994 & -121.8896 & 0 & 5 \\
\hline \multicolumn{6}{|l|}{ Butte County } \\
\hline $\begin{array}{l}\text { Sacramento River, Mile } 188 \text { (W of } \\
\text { Murphy's Slough) }\end{array}$ & 123 & 39.6662 & -121.9823 & - & 1 \\
\hline Sacramento River, Mile 180.5-1 (Llano Seco) & 99 & 39.5813 & -121.9932 & 15 & 33 \\
\hline Gray Lodge WA, Colony 1 & 57 & 39.3153 & -121.8619 & 0 & 19 \\
\hline \multicolumn{6}{|l|}{ Colusa County } \\
\hline $\begin{array}{l}\text { Butte Sink, nr. confluence Butte Creek and } \\
\text { Angel Slough }\end{array}$ & 54 & 39.3419 & -121.8952 & 0 & 100 \\
\hline
\end{tabular}




\begin{tabular}{|c|c|c|c|c|c|}
\hline Site & $\begin{array}{c}\text { Elevation } \\
(\mathrm{ft})\end{array}$ & Latitude & Longitude & $\begin{array}{c}\text { Estimated } \\
\text { pairs } \\
1998- \\
1999^{c} \\
\end{array}$ & $\begin{array}{c}\text { Estimated } \\
\text { pairs } \\
2009- \\
2012 \\
\end{array}$ \\
\hline Colusa NWR, T14.4 & 42 & 39.1530 & -122.0319 & 0 & 3 \\
\hline \multicolumn{6}{|l|}{ Sutter County } \\
\hline North Butte Country Club, Butte Sink & 52 & 39.2728 & -121.8964 & 65 & 0 \\
\hline Sutter Bypass W, N of Nelson Slough & 27 & 38.9016 & -121.6369 & 0 & 1 \\
\hline Sutter Bypass W, E of Knight's Landing & 18 & 38.8249 & -121.6613 & 0 & 15 \\
\hline Sutter Bypass, $\sim 8 \mathrm{~km}$ NE of Knights Landing & 30 & 38.8394 & -121.6578 & 12 & 0 \\
\hline \multicolumn{6}{|l|}{ Yolo County } \\
\hline Sacramento River, Mile 102.5 (Beaver Lake) & 32 & 38.8876 & -121.8124 & 16 & 44 \\
\hline Knights Landing Ridge Cut & 27 & 38.7615 & -121.6974 & - & 2 \\
\hline Port of Sacramento & 8 & 38.5644 & -121.5554 & 0 & 1 \\
\hline \multicolumn{6}{|l|}{ Solano County } \\
\hline Bohannon & 6 & 38.1827 & -121.9565 & 0 & 158 \\
\hline Wheeler & 4 & 38.0786 & -121.9659 & 110 & 80 \\
\hline Spoonbill & 3 & 38.0547 & -121.8934 & 0 & 25 \\
\hline Hass Slough & -2 & 38.3020 & -121.7289 & - & 4 \\
\hline Prospect Slough & -2 & 38.2855 & -121.6641 & - & 6 \\
\hline \multicolumn{6}{|l|}{ Sacramento County } \\
\hline $\begin{array}{l}\text { American River, Mississippi Bar } \\
\text { Stone Lakes NWR }\end{array}$ & \multicolumn{4}{|c|}{ Stone Lakes NWR } & 37 \\
\hline North Stone Lake & 7 & 38.3865 & -121.4877 & 154 & 26 \\
\hline Sun River & 7 & 38.3374 & -121.4981 & 0 & 30 \\
\hline SRCSD Bufferlands, Morrison Creek \# 1 & 6 & 38.4472 & -121.4815 & 0 & 53 \\
\hline Cosumnes River Preserve, Horseshoe Lake & 35 & 38.3430 & -121.3243 & 3 & 17 \\
\hline Pellandini Ranch, W of Twin Cities & 18 & 38.2843 & -121.3672 & 29 & 0 \\
\hline Ecoregion total & & & & 404 & 660 \\
\hline \multicolumn{6}{|l|}{ SAN JOAQUIN VALLEY } \\
\hline \multicolumn{6}{|l|}{ Contra Costa County } \\
\hline Eucalyptus Island & 11 & 37.8589 & -121.5755 & 0 & 27 \\
\hline \multicolumn{6}{|l|}{ Alameda County } \\
\hline $\begin{array}{l}\text { Arroyo del Valle, Shadow Cliffs Regional } \\
\text { Park }\end{array}$ & 357 & 37.6652 & -121.8324 & $1^{h}$ & 23 \\
\hline \multicolumn{6}{|l|}{ San Joaquin County } \\
\hline Potato Slough & 17 & 38.0833 & -121.5571 & 0 & 20 \\
\hline Venice Tip (\#1 and \#2) & 20 & 38.0450 & -121.5306 & 9 & 210 \\
\hline \multicolumn{6}{|l|}{ Stanislaus County } \\
\hline San Joaquin River NWR, Christman Island & 33 & 37.6323 & -121.1995 & 12 & 0 \\
\hline \multicolumn{6}{|l|}{ Merced County } \\
\hline $\begin{array}{l}\text { San Joaquin River, Mile } 121 \text { (SE of Hills } \\
\text { Ferry) }\end{array}$ & 58 & 37.3348 & -120.9509 & 0 & 20 \\
\hline \multicolumn{6}{|l|}{ San Luis NWR } \\
\hline Colony 8 (FT-1A) & 67 & 37.2984 & -120.8876 & 0 & 1 \\
\hline Colony 1, San Joaquin River & 71 & 37.2696 & -120.8301 & 0 & 10 \\
\hline Colony 5 (WB-3) & 78 & 37.2516 & -120.8149 & 22 & 5 \\
\hline Eastside Canal 1 & 91 & 37.2746 & -120.7458 & 0 & 7 \\
\hline San Joaquin River, Turner Island & 92 & 37.1549 & -120.7426 & 0 & 60 \\
\hline \multicolumn{6}{|l|}{ Madera County } \\
\hline San Joaquin River, Sycamore Island & 263 & 36.8520 & -119.8270 & 0 & 6 \\
\hline \multicolumn{6}{|l|}{ Fresno County } \\
\hline San Joaquin River, Mile 242.5 & 224 & 36.8356 & -119.9387 & - & 1 \\
\hline
\end{tabular}




\begin{tabular}{|c|c|c|c|c|c|}
\hline Site & $\begin{array}{l}\text { Elevation } \\
(\mathrm{ft})\end{array}$ & Latitude & Longitude & $\begin{array}{c}\text { Estimated } \\
\text { pairs } \\
1998- \\
1999^{c} \\
\end{array}$ & $\begin{array}{c}\text { Estimated } \\
\text { pairs } \\
2009- \\
2012 \\
\end{array}$ \\
\hline $\begin{array}{l}\text { San Joaquin River, Milburn Unit, SJR } \\
\text { Ecological Reserve }\end{array}$ & 240 & 36.8522 & -119.8735 & 9 & 52 \\
\hline Leaky Acres & 333 & 36.7912 & -119.7352 & - & 5 \\
\hline \multicolumn{6}{|l|}{ Kings County } \\
\hline $\begin{array}{l}\text { South Wilbur Flood Area, Tulare Lake } \\
\text { Drainage District }\end{array}$ & 195 & 35.8748 & -119.6570 & 119 & 90 \\
\hline East Hacienda Ranch Flood Basin, Tulare & & 35.8253 & -119.6086 & & \\
\hline \multirow{2}{*}{\multicolumn{6}{|c|}{ Tulare County }} \\
\hline & & & & & \\
\hline \multirow{2}{*}{\multicolumn{6}{|c|}{ Kern County }} \\
\hline & & & & & \\
\hline Kern County Water Agency & 409 & 35.3974 & -119.0371 & - & 10 \\
\hline Costerisan Farms Lake & 329 & 35.2334 & -118.9826 & - & 10 \\
\hline Ecoregion total & & & & 178 & 563 \\
\hline \multicolumn{6}{|l|}{ CASCADE RANGE } \\
\hline \multicolumn{6}{|l|}{ Siskiyou County (part) } \\
\hline Lake Shastina (north) & 2809 & 41.5156 & -122.3922 & $8^{i}$ & 41 \\
\hline \multicolumn{6}{|l|}{ Lassen County } \\
\hline \multicolumn{6}{|l|}{ Eagle Lake } \\
\hline Pelican Point & 5122 & 40.6333 & -120.7459 & 118 & 0 \\
\hline Island between Buck Pt. and Little Troxel Pt. & 5111 & 40.6594 & -120.7147 & 0 & 2 \\
\hline \multicolumn{6}{|c|}{ Plumas County (part) } \\
\hline Lake Almanor, Almanor Peninsula & 4529 & 40.2641 & -121.1571 & - & 15 \\
\hline Ecoregion total & & & & 126 & 58 \\
\hline \multicolumn{6}{|l|}{ SIERRA NEVADA } \\
\hline \multicolumn{6}{|l|}{ Plumas County (part) } \\
\hline Butt Valley Reservoir & 4145 & 40.1458 & -121.1836 & 24 & 11 \\
\hline \multicolumn{6}{|l|}{ Yuba County } \\
\hline Yuba River, above Daguerra Point Dam & 132 & 39.2167 & -121.4363 & 0 & 1 \\
\hline Ecoregion total & & & & 24 & 12 \\
\hline \multicolumn{6}{|l|}{ MODOC PLATEAU } \\
\hline \multicolumn{6}{|l|}{ Siskiyou County (part) } \\
\hline Butte Valley WA (Meiss Lake) & 4241 & 41.8559 & -122.0620 & 84 & 0 \\
\hline Lower Klamath NWR (Sheepy Lake) & 4083 & 41.9697 & -121.7875 & 62 & 79 \\
\hline \multicolumn{6}{|l|}{ Modoc County } \\
\hline Tule Lake NWR (lower) Sump 1-B & 4040 & 41.8396 & -121.4477 & 172 & 0 \\
\hline Clear Lake NWR & 4484 & 41.8722 & -121.0922 & 114 & 126 \\
\hline Ecoregion total & & & & 432 & 205 \\
\hline \multicolumn{6}{|l|}{ SONORAN DESERT } \\
\hline \multicolumn{6}{|l|}{ Riverside County (part) } \\
\hline \multicolumn{6}{|l|}{ Salton Sea } \\
\hline $76^{\text {th }}$ Ave. & -233 & 33.5018 & -116.0745 & 0 & 1 \\
\hline Johnson Street & -233 & 33.5183 & -116.0594 & $(2)$ & 0 \\
\hline \multicolumn{6}{|l|}{ Imperial County } \\
\hline \multicolumn{6}{|l|}{ Salton Sea } \\
\hline East side Poe Road & -233 & 33.1006 & -115.7342 & (13) & 0 \\
\hline New River mouth & -233 & 33.1336 & -115.6947 & $(30)$ & 0 \\
\hline Alamo River delta & -230 & 33.2083 & -115.6169 & $(106)$ & 0 \\
\hline Mallard Road duck club & -214 & 33.3179 & -115.6155 & 0 & 1 \\
\hline
\end{tabular}




\begin{tabular}{|c|c|c|c|c|c|}
\hline$\underline{\text { Site }}$ & $\begin{array}{c}\text { Elevation } \\
(\mathrm{ft})\end{array}$ & Latitude & Longitude & $\begin{array}{c}\text { Estimated } \\
\text { pairs } \\
1998- \\
1999^{c} \\
\end{array}$ & $\begin{array}{c}\text { Estimated } \\
\text { pairs } \\
2009- \\
2012 \\
\end{array}$ \\
\hline Mullet Island & -200 & 33.2252 & -115.6086 & $5425^{j}$ & 6594 \\
\hline Ramer Lake, Imperial WA & -174 & 33.0777 & -115.5129 & (18) & 305 \\
\hline Ecoregion total & & & & 5425 & 6901 \\
\hline Grand total & & & & $7170^{k}$ & 8791 \\
\hline
\end{tabular}

${ }^{a}$ The "interior" survey area excludes coastal colonies on offshore islands or rocks, coastal bluffs, within estuaries, or otherwise within $10 \mathrm{~km}$ of the ocean or estuarine shoreline; in the San Francisco Bay estuary, only colonies inland of the Carquinez Strait at Interstate 80 are included. Data for 1999 , or referred to for that year, from Shuford (2010) unless otherwise noted. - , no survey made.

${ }^{b}$ Ecoregions used here are a subset of those defined in the Jepson manual (Hickman 1993): Northwestern California, Central Western California, Southwestern California, Sacramento Valley, San Joaquin Valley, Cascade Ranges, Sierra Nevada, Modoc Plateau, and Sonoran Desert (Figure 2 in Shuford et al. 2020).

${ }^{c}$ Pairs estimated from direct count of nests ( 1 nest $=1$ pair) unless otherwise noted. All counts in 1999, except for four in 1998, as noted.

${ }^{d}$ Not checked in 1999 , but 175 pairs in 1998.

${ }^{e}$ Not checked in 1999, but 11 pairs in 1998.

Unclear if active in 1999. As of 2014, it had been active irregularly (depending on water levels) for about 15 years (W. Fritz pers. comm.). First available count is of 23 active nests in two sycamores on 18 June 2011 (inactive in 2014; T. Edell pers. comm.).

gBetween the two survey periods, a colony at the Rio Hondo Spreading Grounds had 10 occupied nests on 10 June 2002 (ebird.org/checklist/S52704335).

${ }^{h}$ Not checked in 1999, but 1 pair in 1998.

${ }^{i}$ Not checked in 1999, but 8 pairs in 1998.

${ }^{j}$ In 1999, circumstances warranted treating the entire Salton Sea area (both north and south ends) as a single site. The estimate of nesting pairs for the entire Salton Sea is from the peak single-day (19 February) count of nests on Mullet Island, given that the relatively small number of nests established elsewhere at the Salton Sea after late February may have represented the relocation of adults that failed earlier at Mullet (see methods in Shuford 2010).

${ }^{k}$ The discrepancy between the 6865 pairs reported in Shuford (2010) for the 1999 survey and the 7170 reported here for 1998-1999 reflects (a) a slight enlargement of the interior survey area in 2009-2012, to include Suisun Marsh, and a comparable retrospective enlargement of the 1999 survey area, leading to the addition of a count of 110 pairs at one site in Suisun Marsh in 1999 that was not included in the prior total, and (b) the inclusion of data on four colonies counted in 1998 but not 1999.

water levels. In the San Joaquin Valley, our surveys in 2012 followed a very dry winter, and since 2006-07 drought had been broken only in 2010-11. Overall, water levels were below average in 2012, but some flood-storage basins periodically important to nesting cormorants (e.g., South Wilbur Flood Area) had extensive water remaining from the wet winter of 2010-11. In other ecoregions, the effects, if any, of drought on the cormorant's nesting or foraging habitats were not obvious but may have been subtle (see discussion for herons and egrets in Shuford et al. 2020).

\section{DATA SUMMARY AND PRESENTATION}

\section{Ecoregions}

We summarize the distribution of colonies of cormorants by 11 ecoregions defined in the Jepson manual (Hickman 1993) and described in Shuford et al. (2020): Northwestern California, Central Western California, South- 
western California, Sacramento Valley, San Joaquin Valley, Cascade Ranges, Sierra Nevada, Modoc Plateau, East of Sierra Nevada, Mojave Desert, and Sonoran Desert (Figure 2 in Shuford et al. 2020). In the Jepson system, the Sacramento-San Joaquin River delta is not a distinct subregion but parts are included in both the Sacramento Valley and San Joaquin Valley subregions.

\section{Mapping}

The maps showing the distribution and relative size of cormorant colonies in 1998-1999 and 2009-2012 were created in ArcMap version 10.5.1 (ESRI, Inc.); values for categories of relative abundance were based on natural breaks in the data pooled over both periods. The Mullet Island colony at the Salton Sea, by far the largest colony recorded, represents the highest abundance category for each survey period.

\section{RESULTS}

\section{Abundance and Distribution}

We estimate that 8791 pairs of Double-crested Cormorants nested in the interior of California from 2009 to 2012 (Table 1). Though this number exceeds the 7170 pairs estimated during the comparable survey in 1998 and 1999, according to the ANOVA these numbers do not differ significantly $\left(F_{8}, 62=0.003, P=0.96\right)$. Within an ecoregion, cormorant numbers were generally consistent, on average, between survey periods $\left(F_{8,62}=0.012, P=\right.$ 0.99 ). Not surprisingly, the totals differed significantly by ecoregion because of substantially more cormorants nesting in the Sonoran Desert than in other ecoregions $\left(F_{8,8}=57.0, P<0.001\right)$. Among other ecoregions, abundance did not differ significantly $\left(F_{7,7}=57.0, P=0.10\right.$; Table 1$)$. The average size of a cormorant colony, however, did not differ significantly by ecoregion, between the survey periods $\left(F_{8,62}=0.99, P=0.45\right)$, or within either the 1998-1999 $\left(F_{8,53}=0.81, P=0.60\right)$ or $2009-2012\left(F_{8,62}=1.02, P=0.43\right)$ rounds of surveys. Removing the Mullet Island colony from the analysis did not significantly alter these results. Although our analyses found no clear underlying differences between survey periods, we strongly caution against concluding there was no change because the substantial practical limits and constraints of the available data suggest that they may lack the precision needed to confirm a trend.

From 2009 to 2012, cormorants were breeding in 9 of the 11 ecoregions (Table 2, Figure 1), but $75 \%$ of the pairs were concentrated at one site-Mullet Island, Imperial County, at the south end of the Salton Sea in the Sonoran Desert ecoregion (79\% of statewide total; Tables 1 and 2). Notably, the total of 6901 pairs for the Sonoran Desert ecoregion (including Mullet Island and other sites at the Salton Sea and adjacent Imperial Valley) was just 289 pairs fewer than the estimated total for the entire interior of California in 1998 and 1999. The ecoregions with the next highest proportions were the Sacramento Valley and San Joaquin Valley with about $8 \%$ and $6 \%$ of the total, respectively (Table 2). In 1998 and 1999, cormorants also bred in the same 9 ecoregions, and the Salton Sea/Sonoran Desert ecoregion similarly accounted for $76 \%$ of the statewide interior total; the Sacramento Valley and Modoc Plateau ecoregions each held 6\% (Tables 1 and 2, Figure 2). 
TABLe 2 Percentage of Nesting Pairs (and Number of Colonies) of Double-crested Cormorants by Ecoregion from Statewide Surveys of the Interior of California, 1998-1999 and 2009-2012

\begin{tabular}{lcc}
\hline Ecoregion $^{a}$ & $1998-1999$ & $2009-2012$ \\
\hline Northwestern California & $5(5)$ & $1(4)$ \\
Central Western California & $<1(2)$ & $<1(2)$ \\
Southwestern California & $3(5)$ & $3(4)$ \\
Sacramento Valley & $6(8)$ & $8(21)$ \\
San Joaquin Valley & $2(7)$ & $6(18)$ \\
Cascade Ranges & $2(2)$ & $<1(3)$ \\
Sierra Nevada & $<1(1)$ & $<1(2)$ \\
Modoc Plateau & $6(4)$ & $2(2)$ \\
East of Sierra Nevada & 0 & 0 \\
Mojave Desert & 0 & 0 \\
Sonoran Desert & $76(1)^{b}$ & $79(4)$ \\
\hline
\end{tabular}

${ }^{a}$ As defined in the Jepson Manual: Higher Plants of California (Hickman 1993; Figure 2 in Shuford et al. 2020).

${ }^{b}$ Number of colonies in this ecoregion does not include five colonies at the Salton Sea that may have represented the relocation of adults that failed earlier at the large colony at Mullet Island (Table 1; Methods in Shuford 2010).

From 2009 to 2012, cormorants nested in at least 60 colonies. In 1998 and 1999, when coverage was less extensive, colonies numbered 35 (Table 1). The total for 1998-1999, however, does not include five colonies at the Salton Sea that may have represented birds that relocated after an early-season abandonment of the large Mullet Island colony. The Sacramento Valley and San Joaquin Valley ecoregions accounted for 35\% and 30\%, respectively, of the total number of colony sites from 2009 to 2012; colony sites were more evenly distributed among ecoregions in 1998 and 1999 (Tables 1 and 2, Figures 1 and 2).

\section{DISCUSSION}

\section{Population Trends in California}

Grinnell and Miller (1944) described the Double-crested Cormorant as resident and "locally common" in California, with a "marked reduction in numbers of individuals and breeding colonies noted in recent years." With continued declines through the 1970 s from habitat loss, human disturbance, and contaminants this cormorant was designated a species of special concern in California (Remsen 1978). But after population increases in subsequent decades this designation was dropped (Shuford and Gardali 2008).

Carter et al. (1995) concluded that historic declines and extirpations at coastal colonies in northern and central California probably paralleled declines that began in the mid- to late 1880 s at the South Farallon Islands, where numbers remained low until the 1970s. Numbers of breeding Doublecrested Cormorants began to expand elsewhere in northern California in the 1960 s and at the Farallons in the 1970s. The species colonized San Francisco 
Bay in the late 1970s, subsequently breeding mainly on artificial structures such as bridges, and has since increased to nearly 3500 pairs in peak years (Rauzon et al. 2019).

Colonies in southern California declined from the early 1900s through the 1970s, then increased (Carter et al. 1995). Total numbers of nests on the California coast increased from $<1000$ per year $(1975-1980)$ to about 4400 (1989-1991) to about 6600 (2001-2003), then decreased to about 5000 in 2008 (Hunt et al. 1979, Sowls et al. 1980, Carter et al. 1992, 1995, Capitolo et al. 2004, Adkins et al. 2014, as summarized in Capitolo et al. 2019). The lower total in 2008 likely reflected a temporary reduction in prey (not associated with El Niño), particularly a decrease in the number and size of the Northern Anchovy (Engraulis mordax) in central California (Capitolo et al. 2019).

In the interior, the Double-crested Cormorant has bred widely. Although there are few data on historic colony sizes, some sites held hundreds and perhaps thousands of nesting pairs (Remsen 1978, Shuford 2010:44-53 and Appendix 6). Massive loss of wetlands and alteration of the state's natural hydrology earlier in the 20th century for agricultural and urban needs (see Shuford et al. 2001, Garone 2011) caused marked reductions in cormorant numbers and colonies (Grinnell and Miller 1944, Carter et al. 1995, Shuford 2010: Appendix 6). The loss of large lakes (e.g., Tulare and Buena Vista lakes) and the diminution of the size or quality of others (e.g., Tule and Eagle lakes) have had the greatest long-term effect on interior populations. It is unknown to what degree these losses were offset (or exceeded?) by the subsequent creation of reservoirs or human-altered sites such as the Salton Sea, where numbers have spiked, then abruptly declined, in recent years as outlined below. In the interior of southern California away from the Salton Trough, cormorants formerly may not have bred until the creation of reservoirs (with introduced or invasive non-native fish) supplied foraging habitat and the planting of large non-native trees supplied nest substrate.

The only interior cormorant colonies with a fairly continuous record of numbers since the early 1950s are Tule Lake, Lower Klamath, and Clear Lake national wildlife refuges (NWR) (Shuford 2010, Table 3). Although numbers at these sites show no clear trends, they appear not to be representative of the increase for California as a whole. Carter et al. (1995) estimated that at least 2806 individuals bred at inland colonies in the early 1990s but acknowledged that the interior had not been surveyed adequately. As the two comprehensive surveys of breeding cormorants in the interior yielded 7170 and 8791 pairs, the total for the interior may be about a third greater than the total for the California coast, in favorable years. But when conditions at the Salton Sea are poor (i.e., Mullet Island is unavailable, prey is scarce) the interior total may be one half or less of the coastal total.

Although the Double-crested Cormorant's history of breeding in the interior of California is fragmentary, it appears that total numbers at inland colonies have increased since the 1970s, as they have on the coast (Carter et al. 1995). Limitations of the surveys, dynamic conditions, and large and rapid population changes at some key sites make assessing trends difficult, however. For example, a drop in numbers at the Sheepy Lake colony at Lower Klamath NWR from 978 pairs in 1997 to 62 pairs in 1999 apparently resulted from water levels being kept too high in 1999 , with the result that many of the tule- 
mat islands on which the cormorants nested were inundated and saturated (D. Mauser pers. comm.). Cormorant numbers can vary widely at the local and regional level between periods of flood and drought. For example, in 2009, when we surveyed the three ecoregions of northeastern California during an extended drought, numbers there were lower than in 1999, following a very wet period. Specifically, though an estimated 118, 84, and 172 pairs of cormorants nested at Eagle Lake, Butte Valley Wildlife Area (Meiss Lake), and Tule Lake NWR, respectively, in 1999, none used those sites in 2009, when falling water levels eliminated all potential nesting habitat.

The cormorant population at the Salton Sea has been particularly dynamic (Molina and Sturm 2004, Hurlbert et al. 2007, Shuford 2010). After estimates of up to 500 nesting pairs in the early 20th century, through the late $1980 \mathrm{~s}$ numbers rarely exceeded 100 pairs (Shuford 2010). Cormorants did not nest at the Salton Sea from 1989 to 1994 (Molina and Sturm 2004), and only 56 pairs nested in 1995 (Hurlbert et al. 2007, Shuford 2010). After colonization of Mullet Island in 1996, cormorants reached a peak of about 5425 pairs in 1999 (Table 2 in Shuford et al. 2002), but none were observed nesting there from 2001 to 2003 (Molina and Sturm 2004, D. Anderson in litt.). Following recolonization in 2004 (Molina pers. obs.), the number nesting on Mullet reached an estimated 6594 pairs in 2012 (this study). Despite a steady decline in water levels that left only shallow water between the island and the mainland, aerial photos taken on 12 March 2013 showed many hundreds of active nests on Mullet Island [K. Riesz and S. Przeklasa née Haynes, Calif. Dept. Fish and Wildlife (CDFW)]. With a continuing decline in water levels that enabled land predators and vehicles to reach the island easily, the colony was abandoned in 2014 and has remained inactive through 2020 (T. Anderson, Salton Sea NWR, and S. Przeklasa née Haynes in litt.).

Most prior fluctuations in cormorant populations at the Salton Sea appear to reflect changes in local prey populations. Hurlbert et al. (2007) assessed variation in the numbers of waterbirds at the Salton Sea on the basis of data from local surveys of colonial waterbirds (1987-1999), the two local Christmas Bird Counts (CBCs) (mainly 1968-2004), and the Breeding Bird Survey (BBS) for the western United States (1968-2002). Fluctuations in fish-eating waterbirds, including the Double-crested Cormorant, closely tracked fish populations over their two cycles of boom and bust from the 1970s to the early 2000s. Molina and Sturm (2004) concluded that because potentially suitable habitat for waterbird colonies had remained constant from the mid-1980s to late 1990s, rapid increases in some species, including the cormorant, in the mid- to late 1990s were best explained by changes in the availability of food rather than of nest sites. These large changes over a few years suggest that patterns supported only by sporadic anecdotal data should be interpreted very cautiously.

The apparent increase in the numbers of breeding pairs and colonies of the Double-crested Cormorant in the interior of California since 1998-1999 reflects primarily the (short-lived) increase in numbers at the Salton Sea, an increasing number of colonies and breeding pairs in the Central Valley, and, to a lesser degree, better coverage on the recent surveys. Despite a lack of a statistically significant population trend from 1998-1999 to 2009-2012, given the limitations of the data, the pattern of greater numbers in the interior of 


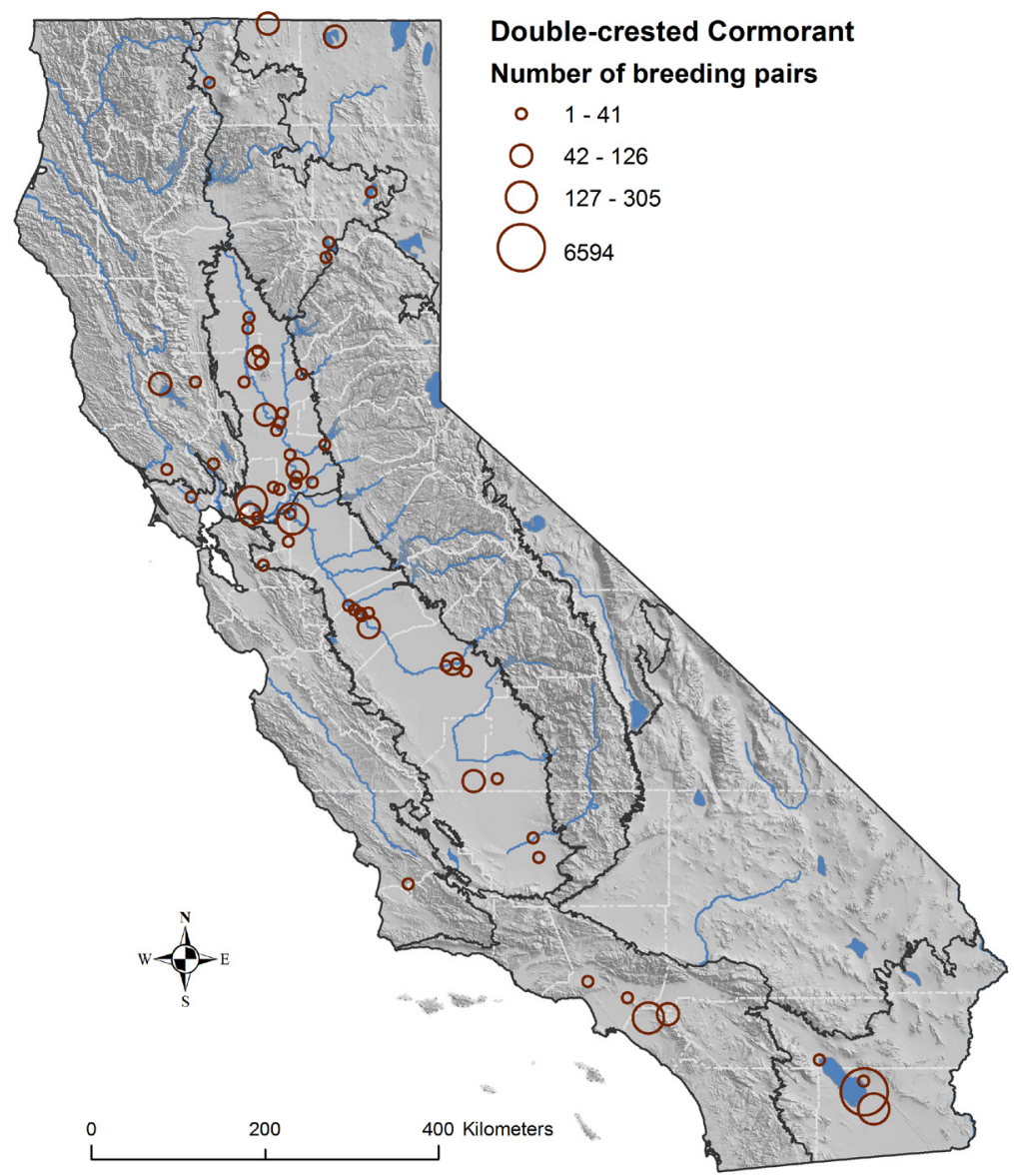

FIGURE 1. Distribution and relative size of Double-crested Cormorant colonies in the interior of California from statewide surveys, 2009-2012 (see Table 1).

California is consistent with an increase in the overall breeding population along the Pacific coast and over much of western North America through the early 2000s (Carter et al. 1995, Adkins et al. 2014), followed since by a leveling off in both regions (Capitolo 2019, Rauzon et al. 2019, USFWS 2019). The colony at Mullet Island at the Salton Sea was the second largest colony in western North America from at least the late 1990s to 2012, exceeded in size by only East Sand Island at the mouth of the Columbia River, Oregon. In fact, the count of 6594 pairs at Mullet Island in 2012, two years before its abandonment, was equivalent to about $21 \%$ of the approximately 31,200 pairs Adkins et al. (2014) estimated for western North America (exclusive of Alaska and northwestern Mexico) circa 2009.

Other sources provide data on cormorant numbers away from colonies 




FIgURE 2. Distribution and relative size of Double-crested Cormorant colonies in the interior of California from statewide surveys, 1998-1999 (see Table 1). Includes five colonies at the Salton Sea and Imperial Valley (not included in calculation of total breeding pairs) that may have represented birds that relocated after an early-season abandonment of the large Mullet Island colony.

but have their limitations. Although the Double-crested Cormorant occurs in California year round, it is not clear if numbers in winter are augmented substantially by influxes of birds from elsewhere or how well-suited the CBC is to tracking trends in these waterbirds. The BBS records data on many species of birds, including this cormorant, but the methods generally are inadequate for colonial waterbirds and tend to undersample marshes (Bystrak 1981, Robbins et al. 1986).

For the periods 1968-2012 and 2002-2012 (i.e., through the last year of our surveys), BBS data for the Double-crested Cormorant showed a signifi- 
cant increase for California but no significant trend for the Western BBS Region as a whole (Sauer et al. 2014). For the period 1978-2014, Pandolfino and Handel (2018) found a significant increase in numbers of the Double-crested Cormorant on CBCs in California's Central Valley. Even with the limitations of all these studies, it is still clear that the Double-crested Cormorant has increased greatly as a breeder in the interior of California in the last 40 to 50 years. This trend, however, may now be reversed with the abandonment of the former premier colony at Mullet Island at the Salton Sea.

\section{Population Shifts}

Presumably the large number of cormorants that last nested at Mullet Island in 2013 have shifted elsewhere to breed. Nevertheless, this loss has been only partly offset by an increase in the numbers of cormorants nesting at Finney and Ramer lakes in the Imperial Valley and a short-lived colony on islands in pond 513A of the Wister Unit of Imperial Wildlife Area adjacent to the Salton Sea, which had a peak of 75 nests when established in 2014 (Molina unpubl. data). In 2015, an estimated 60, 467, and 725 pairs nested at these three sites, respectively. Subsequently, numbers have decreased, with totals for these sites ranging from 9 to 118 nests from 2017 to 2019 (S. Przeklasa née Haynes in litt.). Previously, large numbers nested at Ramer Lake, e.g., 925 nests estimated on 17 May 2011 (D. Anderson in litt.). Regardless, the total of 1252 nests for the three other active colonies in 2015, when the Mullet colony was inactive, represents only $18 \%$ of the combined numbers of nesting pairs at Mullet Island (6594) and Ramer Lake (305) in 2012.

Despite the sharp drop in the number of cormorants breeding at the Salton Sea after the abandonment of Mullet Island in 2014, there is no evidence of a sharp spike in numbers breeding in 2014 or subsequently on islands along the Pacific coast of the Baja California peninsula (Bedolla-Guzmán et al. 2019), in the Gulf of California (including at the largest known colony there at Isla Alcatraz; D. Anderson, E. Clark, J. Martínez Reyes in litt.), or on California's coast or islands (P. Capitolo in litt.). It is possible, however, that large numbers of Double-crested Cormorants may have shifted from the Salton Sea to colonies in mangroves on the west coast of mainland Mexico (south to about $28^{\circ}$ $\mathrm{N}$ ), where there are (or have been) seemingly large numbers nesting but no adequate data from multi-year surveys. Given the difficulty of identification at a distance in the mangroves, it is also possible that many of these birds are Neotropical Cormorants (Phalacrocorax brasilianus) (D. W. Anderson and E. W. Clark in litt.), which are expanding their range northward (Telfair and Morrison 2020). It is also possible that the large numbers of cormorants that abandoned the Salton Sea after 2013 may have spread so widely among colonies over so large a region that no influx to any one colony has been large enough to attract biologists' attention.

Band recoveries, satellite tagging, and genetic studies provide evidence that some cormorants wintering (October-March) at the Salton Sea come from distant colonies to the north, but local breeders may have strong connectivity with northwestern Mexico. Banded or tagged juveniles and adults dispersing or migrating from breeding sites in the Columbia River estuary move both north and south, but just a few have reached the Salton Sea and mouth of the Colorado River in the upper Gulf of California (Clark et al. 
2006, Courtot et al. 2012). The genetic diversity of cormorants from coastal southern California and the Salton Sea/Imperial Valley is high, suggesting that lineages of multiple origins may converge in these areas. Haplotypes found in southern California that are unique within the U.S. and Canada may be derived from cormorants from northwestern Mexico, and thus represent northward movement and introgression between previously isolated lineages (Mercer et al. 2013).

\section{Climatic Variation}

Over the last 20 years, climatic conditions in California have been highly variable, ranging from very wet to extremely dry. Statewide surveys of the Double-crested Cormorant and other colonial waterbirds in the interior of California from 1997 to 1999 took place during a period of precipitation well above average (Shuford 2010), whereas comparable surveys from 2009 to 2012 overlapped with the extended drought that began in winter 2006-07. Despite being interrupted by one wet year (129\% of long-term mean in 2010-11), this dry period persisted four years beyond the completion of our surveys in 2012 (Shuford et al. 2020). The dry period from 2011-12 to 2015-16, alone, is considered the most severe statewide drought in the historical record (Swain 2015, Wang et al. 2017). Furthermore, the 2000-2018 drought in southwestern North America, including California-driven by natural variability superimposed on drying from anthropogenic warming-was the second driest 19-year period since 800 CE (Williams et al. 2020).

The lack of long-term monitoring of the populations of colonial waterbirds in the interior of California limits the conclusions we can draw on the drought's effects. But the regional data for the species inventoried both 1997-1999 (wet period) and 2009-2012 (dry period) provide some valuable insights (Shuford 2014a, Shuford et al. 2016, Doster and Shuford 2018). In the drought years, breeding populations of two gull species and three tern species were greatly reduced throughout the inland portion of their California breeding ranges (i.e., the Central Valley and/or northeastern California). In recent decades, drought has affected the Double-crested Cormorant mainly in northeastern California (e.g., in 2009). Conversely, cormorants may nest in trees in some areas in the closed Tulare Basin of the southern San Joaquin Valley only in very wet years, when excess flows are stored in large flood basins such as the South Wilbur Flood Area. In most other inland areas of California cormorants nest in trees and forage in large rivers, lakes, reservoirs, or other bodies of deep water that are available continuously, which insulates them more from the cycles of drought and flood. Regardless, effects on most species, whether monitored or not, undoubtedly intensified after 2012, as the drought continued four more years. Furthermore, future effects may be even greater or more widespread, given projections of 21 st-century increases in the frequency of wet extremes and smaller increases in dry extremes (Swain et al. 2018).

\section{Accuracy and Challenges of Nest Counts}

Shuford et al. (2020) discussed the difficulty of determining how closely counts or estimates of nests or breeding pairs of ardeids represent the actual 
number present and outlined factors influencing the accuracy of counts. Although surveys of Double-crested Cormorants, both 1998-1999 and 2009-2012, followed the same methods used for ardeids in the latter period, the counts for the cormorant in the interior of California are likely more accurate than those for ardeids because a large proportion of cormorants were nesting on the ground on open islands and were counted from aerial photographs. By contrast, most ardeids were nesting in trees or marshes where direct aerial and ground counts were hindered by screening vegetation. The smaller number of cormorants nesting in trees were generally more visible than ardeids, as most were in snags or sparsely foliaged trees, presumably chosen because of the cormorants' limited maneuverability when landing.

Many of the recommendations for censusing breeding ardeids in California (Shuford et al. 2020) also apply to the Double-crested Cormorant. Ideally all surveys should be conducted in a single year as colonies' locations and size can change as water levels and the availability of nest sites or foraging areas fluctuates, or as these or other factors affect the abundance of prey. Evidence continues to accumulate for other species, at least, indicating that what may appear to be a population increase or decrease in one area may simply reflect a shift in concentration of birds within the broader range (Bart et al. 2007, Wilson et al. 2013, Paprocki et al. 2014, Fleskes et al. 2018).

Regardless, summing counts taken over more than one year, as we have done, is often the only feasible way to obtain an overall population estimate of multiple species spread among many colonies over a broad area (e.g., see Carter et al. 1992 for California seabirds). Timing the counts to the peak of nesting is always desirable, but this peak can vary substantially by region. For example, counts of Double-crested Cormorants in May work well in many parts of California, but at the Salton Sea cormorants may begin laying eggs in December or January and the number of nests may peak in mid-February (Shuford 2010, 2014a).

\section{Future Monitoring}

Additional regional and statewide surveys will be necessary for the longterm status of the Double-crested Cormorant in California to be assessed confidently. Seto (2008) proposed a baseline inventory as a step toward a longterm monitoring program for colonial waterbirds throughout the western United States, a program following standardized protocols and methods (e.g., Steinkamp et al. 2003, Jones 2008). For future inventories, census methods should be selected to provide the most accurate results for the particular species, nest substrate, and time of the season. To facilitate comparisons, repeating the protocols and methods used from 2009 to 2012 would be desirable. But modifications might be needed or desirable, as conditions change or knowledge and technology advance. For example, the use of drones (e.g., Ogden 2013) may ultimately improve surveys' accuracy, facilitate logistics, or reduce costs. Shuford et al. (2020) summarized other factors that apply to monitoring waterbirds, including the Double-crested Cormorant, such as the geographic scale and objectives, and coordination with collaborators working at various scales so status and trends can be accurately assessed for the range of scales important to partners. The lack of evidence on where the $\sim 6600$ pairs of cormorants that had abandoned Mullet Island by 2014 may 
have nested in subsequent years emphasizes the need for future surveys to be coordinated over much broader areas of coastal and interior western North America, including northwestern Mexico, and the need for further studies of the cormorant's movements and the connectivity of its populations.

In California, decisions on the frequency of monitoring should take into account the state's great annual variation in precipitation and wide fluctuations in the size of some colonies, the substrates available for nests, foraging areas, and prey abundance. The intervals between surveys should be short, as precipitation may become more variable with climate change (Swain et al. 2018). While the desired levels of precision and ability to detect trends should strongly influence sampling effort, particularly as annual variation in a colony or subregion can be high (Shuford 2010, Capitolo et al. 2019, Rauzon et al. 2019, this study), resource limitations may limit the surveys' frequency. With such limitations it may be necessary to focus on a statistically robust sampling framework that takes into account spatial variation in waterbirds' densities, temporal variability in colony attendance by the stage of the nesting cycle, and differences in the probability of detecting birds that vary by species, habitats, and over time (Steinkamp et al. 2003). The Pacific Flyway Council (2013) considered such factors when it prioritized monitoring of the western population of the Double-crested Cormorant in response to the species' predation on fish of conservation, economic, or social value. Surveys were initially planned for every three years from 2014 to at least 2023. But, by partnering with the U.S. Army Corps of Engineers, from 2014 to 2018 the USFWS (2019) estimated the population annually from surveys of a sample of both coastal and interior colonies in this region. They suggested using caution, however, in comparison of these estimates to prior ones from comprehensive surveys spread over multiple years. Also, because their sampling focuses on monitoring the western population as a whole it may not produce robust results at other scales, given small sample sizes at the subregional level. Hence, we also recommend comprehensive surveys of all known and potential sites in the interior of California, and elsewhere, once per decade.

\section{Threats and Limiting Factors}

In western North America, Double-crested Cormorants have faced varied threats, including unauthorized and regulated shooting, nest destruction, introduction of mammalian predators on islands, organochlorine pollutants, oil spills, gill-net fishing, climatic changes, and habitat loss in the interior from agriculture and water development (Carter et al. 1995). Adkins et al. (2014) concluded that the main factors limiting the western Double-crested Cormorant population currently are predation by the increasing numbers of Bald Eagles (Haliaeetus leucocephalus), human disturbance at colonies, and climatic variation. Along the coast the availability of prey for cormorants may be affected by changes in ocean conditions (e.g., the timing of the onset of upwelling) or climatic cycles (e.g., El Niño-Southern Oscillation). Inland, cormorants face less stable and predictable food resources and nesting sites during periods of severe drought or flooding.

Other important continuing or new threats, at least in the interior of California, include habitat loss and degradation (particularly from over- or reallocation of water), disease, and the long-term effects of climate change 
(Shuford 2010, 2014b). The recent unprecedented California drought emphasizes the importance of reliable water supplies for all waterbirds nesting inland. Beyond desiccation of foraging habitats when water is scarce, water diversions for human uses may facilitate predators' access to nesting islands and emergent trees and snags as water levels drop or sites dry up entirely. Competition for water will only increase as the human population expands unless water-conservation efforts are redoubled.

Areas of California where overallocation of water has been a particular problem in recent years include the Klamath Basin, Central Valley, and Salton Sea (summaries in Shuford 2010). The greatest threat realized, as noted above, was the loss of the huge colony of Double-crested Cormorants on Mullet Island at the Salton Sea in 2014 when the steady decline in water levels (from reallocation of water to coastal cities) gave terrestrial predators access to the colony, forcing its abandonment. Similarly, some snags in which cormorants formerly nested near the shore of the Salton Sea were out of the water in 2012 and no longer suitable for nesting. As of 2020, many snags have fallen, and the remaining ones are subject to disturbance as water levels have receded further (Shuford et al. 2020). Also, the Salton Sea's increasing salinity as its water level drops will ultimately greatly reduce the fish prey crucial to nesting waterbirds. Furthermore, Newcastle disease caused the death of thousands of cormorants (mostly chicks and juveniles) and abandonment of the Mullet Island colony in 1997, 1998, and 2007 (Friend 2002, Hurlbert et al. 2007, T. Anderson/Salton Sea NWR in litt.). Although the California population of the Double-crested Cormorant has increased since the 1970s, with an expanding human population and changing climate such threats may increase.

By contrast, observations from elsewhere in North America suggest nesting cormorants may displace some species of ardeids locally, by competition for nest sites and, particularly, habitat degradation (e.g., defoliating and killing trees). But there appears to be no evidence of such effects at the regional or population level (Wires et al. 2001). If any such effects are occurring in California they likely are very limited, given that the populations of the five relevant species of herons and egrets appear to be either stable or increasing (Shuford et al. 2020).

\section{ACKNOWLEDGMENTS}

We are deeply indebted to the many individuals and organizations who helped this project in multiple capacities, without whom it would not have been feasible. The many contributors are listed in detail in Shuford (2014a) and Shuford et al. (2020). The scope of the survey effort was greatly expanded by in-kind contributions from collaborating agencies and nonprofit organizations, including Audubon California, Audubon Canyon Ranch, CDFW, Los Angeles Department of Water and Power, Natural History Museum of Los Angeles County, other projects and divisions of Point Blue Conservation Science, San Francisco Bay Bird Observatory, The Nature Conservancy, and U.S. Fish and Wildlife Service. Crucial administrative, logistical, and funding support was provided or facilitated by Bob Altman, Lance Benner, Esther Burkett, Paul Buttner, Neil Clipperton, Lyann Comrack, Rob Doster, Catherine Hickey, Rob Holbrook, Bob Shaffer, Dale Steele, Marie Strassburger, and Bruce Wilcox. We especially thank Lyann Comrack and Rob Doster for their unwavering support and encouragement of this project, which ensured its success. The manuscript was substantially improved by comments from Daniel W. Anderson, Phillip J. 
Capitolo, Emily W. Clark, Mark J. Rauzon, Christopher W. Swarth, and Philip Unitt. Funding for this work was provided by the CDFW (Wildlife Branch-Nongame Wildlife Program), California Rice Commission, Imperial Irrigation District, Pasadena Audubon Society, S. D. Bechtel, Jr. Foundation, U.S. Fish and Wildlife Service's Migratory Bird Program (Region 8) and State Wildlife Grant F10AF00647 to CDFW, and individual contributions to Point Blue Conservation Science. ArcGIS software was generously provided through ESRI's program for nonprofit organizations. This is Point Blue contribution 2297.

\section{LITERATURE CITED}

Adkins, J. Y., Roby, D. D., Lyons, D. E., Courtot, K. N., Collis, K., Carter, H. R., Shuford, W. D., and Capitolo, P. J. 2014. Recent population size, trends, and limiting factors for the Double-crested Cormorant in western North America. J. Wildl. Mgmt. 78:1131-1142; doi.org/10.1002/jwmg.737.

Bart, J., Brown, S., Harrington, B., and Morrison, R. I. G. 2007. Survey trends of North American shorebirds: Population declines or shifting distributions? J. Avian Biol. 38:73-82; doi.org/10.1111/j.2007.0908-8857.03698.x.

Bedolla-Guzmán, Y., Méndez-Sánchez, F., Aguirre-Muñoz, A., et 15 al. 2019. Recovery and current status of seabirds on the Baja California Pacific Islands, Mexico, following restoration actions, in Island Invasives: Scaling up to Meet the Challenge (C. R. Veitch, M. N. Clout, A. R. Martin, J. C. Russell, and C. J. West, eds.), pp. 531-538. Occas. Paper SSC no. 62. IUCN, Gland, Switzerland.

Bystrak, D. 1981. The North American Breeding Bird Survey. Studies Avian Biol. 6:34-41.

Capitolo, P. J., Carter, H. R., Young, R. J., McChesney, G. J., McIver, W. R., Golightly, R. T., and Gress, F. 2004. Changes in breeding population size of Brandt's and Double-crested cormorants in California, 1975-2003. Dept. of Wildl., Humboldt State Univ., Arcata, CA; humboldt-dspace.calstate.edu/handle/2148/930.

Capitolo, P. J., Carter, H. R., Yee, J. L, McChesney, G. J., Parker, M. W., Young, R. J., Golightly, R. T., and Tyler, W. B. 2019. Changes in breeding population sizes of Double-crested Cormorants Phalacrocorax auritus in the Humboldt Bay area, California, 1924-2017. Marine Ornithol. 47:115-126.

Carter, H. R., McChesney, G. J., Jaques, D. L., Strong, C. S., Parker, M. W., Takekawa, J. E., Jory, D. L., and Whitworth, D. L. 1992. Breeding populations of seabirds in California, 1989-1991, vols. 1 and 2. Report to U.S. Fish and Wildl. Serv., Dixon, CA; farallones.noaa.gov/eco/seabird/pdf/news/journal/monitoringandstatus.pdf.

Carter, H. R., Sowls, A. L., Rodway, M. S., Wilson, U. W., Lowe, R.W., McChesney, G. J., Gress, F., and Anderson, D. W. 1995. Population size, trends, and conservation problems of the Double-crested Cormorant on the Pacific coast of North America. Colon. Waterbirds 18 (Spec. Publ. 1):189-215; doi.org/10.2307/1521540.

Clark, A. C., Kollasch, T. M., and Williamson, D. A. 2006. Movements of Doublecrested Cormorants fledged on the Columbia River estuary. Northwest. Nat. 87:150-152; doi.org/10.1898/1051-1733(2006)87[150:MODCFO]2.0.CO;2.

Courtot, K. N., Roby, D. D., Adkins, J. Y., Lyons, D. E., King, D. T., and Larsen, R. S. 2012. Colony connectivity of Pacific coast Double-crested Cormorants based on post-breeding dispersal from the region's largest colony. J. Wildl. Mgmt. 76:1462-1471; doi.org/10.1002/jwmg.403.

Doster, R. H., and Shuford, W. D. 2018. Recent trends in population size and distribution of Ring-billed and California gulls in the western United States, in Trends and traditions: Avifaunal change in western North America (W. D. Shuford, R. E. Gill Jr., and C. M. Handel, eds.), pp. 161-179. Studies of Western Birds 3. W. Field Ornithol., Camarillo, CA; doi.org/10.21199/SWB3.8. 
Fleskes, J. P., Casazza, M. L., Overton, C. T., Matchett, E. L., and Yee, J. L. 2018. Changes in the abundance and distribution of waterfowl wintering in the Central Valley of California, 1973-2000, in Trends and traditions: Avifaunal change in western North America (W. D. Shuford, R. E. Gill Jr., and C. M. Handel, eds.), pp. 50-74. Studies of Western Birds 3. W. Field Ornithol., Camarillo, CA; doi. org/10.21199/SWB3.2.

Friend, M. 2002. Avian disease at the Salton Sea. Hydrobiologia 473:293-306; doi. org/10.1023/A:1016570810004.

Garone, P. 2011. The Fall and Rise of the Wetlands of California's Great Central Valley. Univ. of Calif. Press, Berkeley.

Grinnell, J., and Miller, A. H. 1944. The distribution of the birds of California. Pac. Coast Avifauna 27.

Hickman, J. C. (ed.). 1993. The Jepson Manual: Higher Plants of California. Univ. of Calif. Press, Berkeley.

Hunt, G. L., Jr., Pitman, R. L., Naughton, M., Winnett, K., Newman, A., Kelly, P. R., and Briggs, K. T. 1979. Distribution status, reproductive ecology and foraging habits of breeding seabirds, in Summary of marine mammal and seabird surveys of the Southern California Bight area, 1975-1978, pp. 1-399. Report to U.S. Bur. Land Mgmt., Los Angeles.

Hurlbert, A. H., Anderson, T. W., Sturm, K. K., and Hurlbert, S. H. 2007. Fish and fish-eating birds at the Salton Sea: A century of boom and bust. Lake Reservoir Mgmt. 23:469-499; doi.org/10.1080/07438140709354033.

Jones, S. L. 2008. Western Colonial Waterbird Survey protocols. U.S. Fish and Wildl. Serv., Nongame Migratory Birds Coordinator's Office, Denver; www.fws.gov/ mountain-prairie/migbirds/species/birds/western_colonial/.

Kushlan, J. A., Steinkamp, M. J., Parsons, K. C., et 20 al. 2002. Waterbird conservation for the Americas: The North American Waterbird Conservation Plan, version 1. Waterbird Conservation for the Americas, Washington, DC; www.fws.gov/migratorybirds/pdf/management/northamericawaterbirdconservationplan.pdf.

Mercer, D. M., Haig, S. M., and Roby, D. D. 2013. Phylogeography and population genetic structure of Double-crested Cormorants (Phalacrocorax auritus). Cons. Genet. 14:823-846; doi.org/10.1007/s10592-013-0477-8.

Molina, K. C., and Sturm, K. K. 2004. Annual colony site occupation and patterns of abundance of breeding cormorant, herons, and ibis at the Salton Sea. Studies Avian Biol. 27:42-51.

Ogden, L. E. 2013. Drone ecology. BioScience 63:776-776; doi.org/10.1525/ bio.2013.63.9.18.

Pacific Flyway Council. 2013. A monitoring strategy for the western population of Double-crested Cormorants within the Pacific Flyway. Pacific Flyway Council, U.S. Fish and Wildl. Serv., Portland, OR; pacificflyway.gov/Documents/ Dcc_monitoring.pdf.

Pandolfino, E. R., and Handel, C. M. 2018. Population trends of birds wintering in the Central Valley of California, in Trends and traditions: Avifaunal change in western North America (W. D. Shuford, R. E. Gill Jr., and C. M. Handel, eds.), pp. 215-235. Studies of Western Birds 3. W. Field Ornithol., Camarillo, CA; doi.org/10.21199/SWB3.12.

Paprocki, N., Heath, J. A., and Novak, S. J. 2014. Regional distribution shifts help explain local changes in wintering raptor abundance: Implications for interpreting population trends. PLoS One 9(1):e86814; doi.org/10.1371/journal. pone. 0086814 .

Rauzon, M. J., Elliott, M. L., Capitolo, P. J., Tarjan, L. M., McChesney, G. J., Kelly, J. P., and Carter, H. R. 2019. Changes in abundance and distribution of nesting Double-crested Cormorants Phalacrocorax auritus in the San Francisco Bay area, 1975-2017. Marine Ornithol. 47:127-138. 
Remsen, J. V., Jr. 1978. Bird species of special concern in California: An annotated list of declining or vulnerable bird species. Nongame Wildl. Invest., Wildl. Mgmt. Branch Admin. Rep. 78-1, Calif. Dept. Fish and Game, Sacramento; nrm.dfg. ca.gov/FileHandler.ashx?DocumentID=169067\&inline.

Robbins, C. S., Bystrak, D., and Geissler, P. H. 1986. The Breeding Bird Survey: Its first fifteen years, 1965-1979. Resource Publ. 157, U.S. Fish and Wildl. Serv., Washington, DC.

Sauer, J. R., Hines, J. E., Fallon, J. E., Pardieck, K. L., Ziolkowski, D. J., Jr., and Link, W. A. 2014. The North American Breeding Bird Survey, results and analysis 1966-2012, version 02.19.2014. U.S. Geol. Surv. Patuxent Wildl. Res. Cent., Laurel, MD; www.mbr-pwrc.usgs.gov/bbs/bbs2012.shtml.

Seto, N. W. H. 2008. Coordinated colonial waterbird inventory and monitoring in the western United States: Comprehensive breeding season surveys. U.S. Fish and Wildl. Serv., Migratory Birds and Habitat Programs, Portland, OR; www.fws.gov/mountain-prairie/migbirds/species/birds/western_colonial/.

Shuford, W. D. 2010. Inland-breeding pelicans, cormorants, gulls, and terns in California: A catalogue, digital atlas, and conservation tool. Wildl. Branch, Nongame Wildl. Program Rep. 2010-01. Calif. Dept. Fish and Game, Sacramento; nrm.dfg.ca.gov/FileHandler.ashx?DocumentID =24095 [minus digital atlas].

Shuford, W. D. 2014a. Patterns of distribution and abundance of breeding colonial waterbirds in the interior of California, 2009-2012. Report to Calif. Dept. Fish and Wildl. and U.S. Fish and Wildl. Serv. (Region 8); www.fws.gov/mountainprairie/migbirds/species/birds/western_colonial/.

Shuford, W. D. 2014b. Coastal California (BCR 32) waterbird conservation plan: Encompassing the coastal slope and Coast Ranges of central and southern California and the Central Valley. A plan associated with the Waterbird Conservation for the Americas initiative; www.centralvalleyjointventure.org/assets/ pdf/BCR32_WaterbirdCon_interactive_10FEB14.pdf.

Shuford, W. D., and Dybala, K. E. 2017. Conservation objectives for wintering and breeding waterbirds in California’s Central Valley. San Francisco Estuary Watershed Sci. 15(1): article 4; doi.org/10.15447/sfews.2017v15iss1art4.

Shuford, W. D., and Gardali, T. (eds.). 2008. California Bird Species of Special Concern: A ranked assessment of species, subspecies, and distinct populations of birds of immediate conservation concern in California. Studies of Western Birds 1. W. Field Ornithol., Camarillo, CA, and Calif. Dept. of Fish and Game, Sacramento; www.wildlife.ca.gov/Conservation/SSC/Birds.

Shuford, W. D., Humphrey, J. M., and Nur, N. 2001. Breeding status of the Black Tern in California. W. Birds 32:189-217.

Shuford, W. D., Warnock, N., Molina, K. C., and Sturm, K. K. 2002. The Salton Sea as critical habitat to migratory and resident waterbirds. Hydrobiologia 473:255-274; doi.org/10.1023/A:1016566709096.

Shuford, W. D., Sesser, K. A., Strum, K. M., Haines, D. B., and Skalos, D. A. 2016. Numbers of terns breeding inland in California: Trends or tribulations? W. Birds 47:182-213; doi.org/10.21199/WB47.3.1.

Shuford, W. D., Kelly, J. P., Condeso, T. M., Molina, K. C., Cooper, D. S., and Jongsomjit, D. 2020. Distribution and abundance of colonial-nesting herons and egrets in California, 2009-2012. W. Birds 51:190-220; doi.org/10.21199/WB51.3.2.

Sowls, A. L., DeGange, A. R., Nelson, J. W., and Lester, G. S. 1980. Catalog of California seabird colonies. U.S. Fish and Wildl. Serv. Progr. FWS/OBS 37/80; www. vliz.be/imisdocs/publications/ocrd/273922.pdf.

Steinkamp, M., Peterjohn, B., Byrd, V., Carter, H., and Lowe, R. 2003. Breeding season survey techniques for seabirds and colonial waterbirds throughout North America; www.bu.edu/scscb/working_groups/resources/steinkampsurvey-techniques.pdf. 
Swain, D. L. 2015. A tale of two California droughts: Lessons amidst record warmth and dryness in a region of complex physical and human geography. Geophys. Res. Lett. 42:9999-10,003; doi.org/10.1002/2015GL066628.

Swain, D. L., Langenbrunner, B., Neelin, J. D., and Hall, A. 2018. Increasing precipitation volatility in twenty-first-century California. Nat. Clim. Change 8:427-433; doi.org/10.1038/s41558-018-0140-y.

Telfair R. C. II, and Morrison, M. L. 2020. Neotropic Cormorant (Phalacrocorax brasilianus), in Birds of the World (P. G. Rodewald and B. K. Keeney, eds.), version 2.0. Cornell Lab Ornithol., Ithaca, NY; doi.org/10.2173/bow.neocor.02.

U.S. Fish and Wildlife Service (USFWS). 2019. Double-crested Cormorant western population status evaluation: Final annual 2018 report. Report to U.S. Army Corps of Engineers; www.fws.gov/pacific/migratorybirds/PDF/2018_WP_ DCCO_Final_Annual_Report.pdf.

Wang, S.-Y. S., Yoon, J-H., Becker, E., and Gillies, R. 2017. California from drought to deluge. Nat. Clim. Change 7:465-468; doi.org/10.1038/nclimate3330.

Williams, A. P., Cook, E. R., Smerdon, J. E., Cook, B. I., Abatzoglou, J. T., Bolles, K., Baek, S. H., Badger, A. M., and Livneh, B. 2020. Large contribution from anthropogenic warming to an emerging North American megadrought. Science 368:314-318; doi.org/10.1126/science.aaz9600.

Wilson, S., Anderson, E. M., Wilson, A. S. G., Bertram, D. F., and Arcese, P. 2013. Citizen science reveals an extensive shift in the winter distribution of migratory Western Grebes. PLoS One 8(6):e65408; doi.org/10.1371/journal. pone. 0065408 .

Wires, L. R., and Cuthbert, F. J. 2006. Historic populations of the Double-crested Cormorant (Phalacrocorax auritus): Implications for conservation and management in the 21st century. Waterbirds 29:9-37; doi.org/10.1675/15244695(2006)29[9:HPOTDC]2.0.CO;2.

Wires, L. R., Cuthbert, F. J., Trexel, D. R., and Joshi, A. R. 2001. Status of the Doublecrested Cormorant (Phalacrocorax auritus) in North America. Final report to U.S. Fish and Wildl. Serv.; www.fws.gov/migratorybirds/pdf/management/ doublecrestedcormorantstatus.pdf. 


\title{
COMPARISON OF THE SONGS OF CASSIN'S AND PLUMBEOUS VIREOS
}

\author{
EDWARD R. PANDOLFINO, 1328 49th Street, Sacramento, California 95819; \\ erpfromca@aol.com \\ CHRIS RAY, The Institute for Bird Populations, P.O. Box 1346, Point Reyes \\ Station, California 94956
}

\begin{abstract}
We compared the songs of Cassin's (Vireo cassinii) and Plumbeous (V. plumbeus) Vireos to determine if there are characteristics that could allow one to confidently distinguish between these species by song. Using recordings made in the breeding season and within the undisputed breeding ranges of each species, away from the zone of contact, we compared five characteristics of a song: phrase length, rate of phrase delivery, proportion of frequency-modulated (buzzy) phrases, proportion of doubled phrases, and midpoint frequency between the highest and lowest frequencies of a phrase. Among these, the only character in which the species differed significantly was the average midpoint frequency of song phrases. Despite overlap between the species in the distribution of average midpoint frequency, a criterion of $3215 \mathrm{~Hz}$ allowed $\sim 84 \%$ of the vireo songs in our sample to be identified correctly. We also tabulated expected proportions of true and false positive species identifications based on the full range of average midpoint frequencies likely to be encountered, finding that values $>3410 \mathrm{~Hz}$ have a $>95 \%$ probability of representing Cassin's Vireo, and values $<3050$ have a $>95 \%$ probability of representing the Plumbeous Vireo. Various field guides show conflicting breeding ranges for these species, and there are many field reports of both vireos outside their known breeding ranges in the breeding season. Given that visual identification of these birds in the field can be difficult when individuals are in faded spring/summer plumage, song may allow us to better define the actual limits of these species' breeding ranges.
\end{abstract}

Song is a defining characteristic of many bird species, sometimes playing an important role in promoting reproductive isolation between closely related sympatric species (Sabbekoorn and Smith 2002). Differences in song can also be a significant aid to field identification of such species. Borror (1972) and James (1981) quantitatively compared the songs of the Cassin's, Plumbeous, and Blue-headed Vireos (Vireo cassinii, V. plumbeus, and V. solitarius, respectively), prior to the elevation of these taxa from subspecies to full species status. Borror (1972) noted no significant difference between the songs of Cassin's and Plumbeous Vireos in terms of length of song phrases, rate of phrase delivery, song frequency, number of syllables per phrase, or repertoire size. James (1981) also compared the length of phrases, repertoire size, and frequency, as well as noting the proportion of frequency-modulated elements (often referred to as "buzzy" notes). James noted an apparently significant difference in frequency, with the frequency halfway between the highest and lowest frequencies of a phrase of Cassin's higher, on average, than that of the Plumbeous. In neither study, however, were sample sizes robust. Borror's (1972) comparisons were based on four Cassin's Vireo recordings from Flathead Lake, Montana, and six Plumbeous Vireo recordings, three each from the Catalina Mountains of Colorado and Portal, Arizona. James (1981) used five Cassin's recordings, all from British Columbia, and just two Plumbeous recordings, one each from Texas and Arizona. Some field guides 
have noted this difference in the songs' frequencies (Sibley 2014, Pieplow 2019), and some (Floyd 2008, Sibley 2014, https://www.allaboutbirds.org/ guide/Cassins_Vireo/sounds) have also suggested that the song of the Plumbeous Vireo includes a higher proportion of frequency-modulated phrases. However, the small sample sizes of Borror (1972) and James (1981) and the anecdotal nature of field guide comments do not allow one to infer that song characteristics can be used to distinguish these species, either in the field or from recordings. Hedley (2016) analyzed the repertoire and syntax of Cassin's Vireo song thoroughly but did not compare them with those of the Plumbeous Vireo. Martindale (1980) also studied repertoire and syntax, but of the Blue-headed Vireo only.

Current published range maps disagree considerably about the exact limits of the breeding ranges of Cassin's and Plumbeous Vireos, especially in northeastern California, parts of Wyoming, and central Montana. For example, Sibley (2014) showed the breeding range of the Plumbeous Vireo extending into northeastern California, including areas of southern Modoc County and northern Lassen County, while Dunn and Alderfer (2017) and Goguen and Curson (2012) showed the Plumbeous Vireo's range extending no farther north in California than just south of Lake Tahoe. Sibley (2014) and Dunn and Alderfer (2017) showed most of Wyoming and south-central Montana as within the breeding range of the Plumbeous Vireo, while Goguen and Curson (2012) showed the range extending barely into south-central Wyoming, and into small, isolated portions of northeastern Wyoming and southeastern Montana. Faulkner (2010) also showed the Plumbeous Vireo breeding in Wyoming in the south and in patches throughout the eastern parts of the state. The range maps proposed by Johnson (1995), based on genetic analyses, show the southern tip of the Sierra Nevada in California as the only likely area of sympatry. Johnson (1995) collected specimens from northeastern California where sources differ on the breeding ranges of these two species, and he identified those birds as Cassin's Vireos from genetic data. Sibley (2014) and Dunn and Alderfer (2017) showed no areas of sympatry between these species in Montana, but Marks et al. (2016) showed their ranges overlapping in portions of five Montana counties (Judith Basin, Meagher, Wheatland, Gallatin, and Park).

Much of this uncertainty may be due to the fact that Cassin's Vireos in faded spring and summer plumage can be quite pale (Heindel 1996, Heindel and Heindel 2004, Sibley 2014), making field identification of all individuals in this season problematic. Therefore, we analyzed song recordings from the known breeding ranges of each species to determine if one may use song to more consistently differentiate these species and to resolve some of these uncertainties about the breeding ranges.

\section{METHODS}

\section{Recordings}

We used recordings from the Macaulay Library (www.macaulaylibrary. org), and from www.xeno-canto.org that were made within each species' undisputed breeding range during the breeding season (Figure 1; Tables 1 




FIGURE 1. Locations of recordings analyzed for differences between the songs of the Cassin's and Plumbeous Vireos.

and 2), included at least eight consecutive phrases, and were of good quality (signal-to-noise ratio of approximately 5:1 or better). We also eliminated any recordings of songs elicited by a broadcast, which could have influenced the song given in response. For Cassin's Vireo, we used only recordings made between 15 April and 15 July. Because Cassin's Vireo migrates through much of the breeding range of the Plumbeous Vireo, and because both vireos are known to sing during migration (Pieplow 2019), we restricted the dates of Plumbeous Vireo recordings used to 15 May to 15 July. In total, our dataset included 64 songs, from 32 individuals of each species.

Spectrographic Analysis

We used the software Raven Pro 1.6 (Cornell Laboratory of Ornithology) to make spectrograms and to measure the characteristics of each song. We 
TABLE 1 Metadata for Cassin's Vireo Recordings

\begin{tabular}{|c|c|c|c|c|}
\hline Recording $^{a}$ & Latitude & Longitude & Date & Recordist \\
\hline ML11895 & 46.865 & -117.162 & 17 Jun & Stein, Robert \\
\hline ML22925 & 36.397 & -121.576 & 24 Apr & Fish, William \\
\hline ML22929 & 40.017 & -121.000 & 1 Jun & Fish, William \\
\hline ML22956 & 38.920 & -120.781 & 13 May & Fish, William \\
\hline ML22957 & 39.431 & -123.323 & 10 Jun & Fish, William \\
\hline ML48865 & 39.586 & -120.551 & 10 Jun & Moyer, David \\
\hline ML67833 & 49.792 & -125.001 & 20 May & Gunn, William \\
\hline ML105665 & 43.086 & -124.059 & 8 Jun & Keller, Geoffrey \\
\hline ML105683 & 42.625 & -122.116 & 10 Jun & Keller, Geoffrey \\
\hline ML118826 & 40.315 & -124.314 & 20 May & Keller, Geoffrey \\
\hline ML118837 & 38.777 & -122.743 & 21 May & Keller, Geoffrey \\
\hline ML144046 & 39.776 & -120.472 & 30 May & Little, Randolph \\
\hline XC136030 & 36.313 & -121.571 & 1 Jun & Sullivan, Brian \\
\hline XC16529 & 45.491 & -123.220 & 6 Jun & Jones, Don \\
\hline XC16530 & 44.354 & -121.549 & 8 Jun & Jones, Don \\
\hline XC181413 & 40.101 & -123.796 & 17 May & Cannizzaro, Eric \\
\hline XC195840 & 52.821 & -119.244 & 27 Jun & Webster, Richard \\
\hline XC195911 & 51.900 & -120.036 & 28 Jun & Webster, Richard \\
\hline XC196045 & 50.899 & -118.814 & 28 Jun & Webster, Richard \\
\hline XC34873 & 46.595 & -118.214 & 24 May & Brooks, Tayler \\
\hline XC379329 & 35.968 & -118.418 & $9 \mathrm{Jul}$ & Benner. Lance \\
\hline XC418150 & 53.517 & -123.062 & 1 Jun & Dyck, Jeff \\
\hline XC477500 & 53.867 & -122.757 & 28 May & Bradley, David \\
\hline XC497904 & 39.588 & -120.292 & 16 May & Pandolfino, Ed \\
\hline XC497906 & 39.087 & -120.589 & 11 May & Pandolfino, Ed \\
\hline XC497907 & 39.059 & -120.572 & 27 May & Pandolfino, Ed \\
\hline XC497913 & 39.165 & -120.660 & 26 Jun & Pandolfino, Ed \\
\hline XC497915 & 39.178 & -120.644 & 26 Jun & Pandolfino, Ed \\
\hline XC497917 & 39.689 & -120.473 & 14 Jun & Pandolfino, Ed \\
\hline XC497933 & 39.087 & -120.597 & 27 May & Pandolfino, Ed \\
\hline XC59027 & 39.943 & -121.312 & 30 May & Owens, Luke \\
\hline XC76908 & 37.977 & -120.373 & 16 Apr & Fisher, Stuart \\
\hline
\end{tabular}

${ }^{a}$ Each recording represents one individual. ML, Macaulay Laboratory; XC, Xeno-canto.

chose to measure phrase length, song rate (number of phrases per minute), proportion of phrases that included frequency modulation ("buzziness"), proportion of phrases that were doubled (a phrase composed of two distinct parts with a very short pause in between; Figure 2), and average frequency at the midpoint of each phrase. Following the method of James (1981), we defined the midpoint frequency as the frequency halfway between the highest and lowest frequencies of a phrase, ignoring harmonics when present (Figure 3). For this, we used the selection box tool in Raven Pro 1.6 to determine the high and low frequencies of each phrase, then calculated the midpoint frequency as [(high - low)/2] + low. We then averaged the midpoints of each phrase to obtain a mean midpoint frequency for each recording. To avoid bias in making these measurements, we coded all songs before analysis so that the location of the recording was unknown during analysis. 
TABLE 2 Metadata for Plumbeous Vireo Recordings

\begin{tabular}{|c|c|c|c|c|}
\hline Recording $^{a}$ & Latitude & Longitude & Date & Recordist \\
\hline ML11900 & 39.457 & -105.105 & 22 Jun & Davis, L. Irby \\
\hline ML11901 & 33.169 & -105.781 & 25 May & Allen, Arthur \\
\hline ML11905 & 35.085 & -113.889 & 18 May & Stein, Robert \\
\hline ML25178 & 31.863 & -109.199 & 16 Jun & Barker, Harriette \\
\hline ML40616 & 31.914 & -109.319 & 1 Jun & Keller, Geoffrey \\
\hline ML50222 & 37.441 & -108.242 & 7 Jun & Keller, Geoffrey \\
\hline ML109026 & 31.417 & -110.274 & 19 May & Keller, Geoffrey \\
\hline ML131237 & 30.692 & -104.124 & 29 May & Andersen, Michael \\
\hline ML186615 & 37.383 & -107.926 & 16 Jun & Pieplow, Nathan \\
\hline ML188813 & 40.450 & -108.523 & 21 May & McGuire, Bob \\
\hline ML202863 & 35.897 & -111.875 & 14 Jun & Robbins, Mark \\
\hline ML203254 & 31.429 & -110.289 & 23 Jun & Robbins, Mark \\
\hline ML203282 & 31.784 & -109.304 & 25 Jun & Robbins, Mark \\
\hline XC104898 & 39.029 & -108.630 & 15 Jun & DeFonso, Eric \\
\hline XC109269 & 39.701 & -107.668 & 31 May & Spencer, Andrew \\
\hline XC13651 & 38.219 & -108.520 & 29 May & Spencer, Andrew \\
\hline XC139887 & 44.463 & -104.392 & 26 May & Leite, Gabriel \\
\hline XC14274 & 31.885 & -109.176 & $7 \mathrm{Jul}$ & Parrish, Chris \\
\hline XC179453 & 34.486 & -112.553 & 24 May & Riegner, Micah \\
\hline XC184593 & 40.573 & -111.775 & 30 Jun & Avery, Tim \\
\hline XC205477 & 38.241 & -108.843 & 23 May & DeFonso, Eric \\
\hline XC205865 & 37.363 & -108.952 & 31 May & DeFonso, Eric \\
\hline XC21768 & 31.905 & -109.280 & $14 \mathrm{Jul}$ & Parrish, Chris \\
\hline XC323425 & 31.872 & -109.235 & 11 Jun & Webster, Richard \\
\hline XC324861 & 40.003 & -105.288 & 26 Jun & Floyd, Ted \\
\hline XC325471 & 37.601 & -104.785 & 13 Jun & Riffe, Sue \\
\hline XC372339 & 40.009 & -105.286 & 27 May & Floyd, Ted \\
\hline XC374081 & 38.729 & -104.840 & 2 Jun & Wistrand, Matt \\
\hline XC481057 & 39.012 & -116.378 & 10 Jun & Wilcox, Bobby \\
\hline XC48193 & 32.650 & -109.817 & 7 Jun & Olmstead, Scott \\
\hline XC5564 & 36.669 & -108.305 & 23 Jun & Jones, Don \\
\hline XC5565 & 38.408 & -105.317 & 26 Jun & Jones, Don \\
\hline
\end{tabular}

${ }^{a}$ Each recording represents one individual. ML, Macaulay Laboratory; XC, Xeno-canto.

\section{Analytical Methods}

Given the currently limited number of suitable recordings available from each species ( $n=32$ for each), we adopted a parametric approach to estimating intraspecific variation in song characteristics and overlap between species. We represented intraspecific variation with box plots, and modeled the potential for overlap between species under the assumption of normal (Gaussian) variation in song characteristics. We modeled the natural logarithm of the average midpoint frequency by using a normal distribution with mean and standard deviation $\mu_{C}$ and $\sigma_{C}$ for Cassin's Vireo, $\mu_{P}$ and $\sigma_{P}$ for the Plumbeous Vireo. We then used the parametric 95\% confidence interval for each mean to estimate $95 \%$ confidence intervals on the proportion of individuals that would be identified correctly (true positives) and incorrectly (false positives) given any particular cutoff in average midpoint frequency that might be used as a threshold for distinguishing these two species. To determine how indi- 




Figure 2. Example of a doubled phrase (Cassin's Vireo recorded in Monterey County, California, 24 April by William Fish; Macaulay Library 22925).

vidual recordings affected the optimal cutoff for species identification, and the number of individuals correctly identified, we used leave-one-out crossvalidation. Specifically, we withheld each bird in turn from the estimation of the model's parameters ( $\mu$ and $\sigma$ ), and used the resulting model to identify the species of the bird withheld. Finally, we used logistic regression to test whether the probability of correctly identifying an individual varied with the number of song phrases analyzed for that individual.

\section{RESULTS}

Of the characteristics we measured, phrase length, song rate, proportion of frequency-modulated phrases, and proportion of doubled phrases (Figure

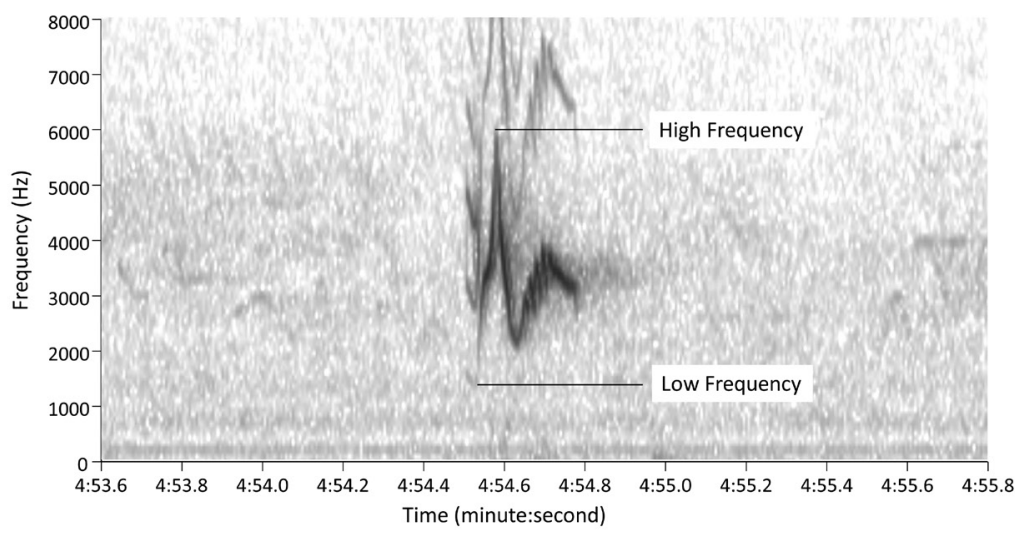

FIGURE 3. Example of determination of a midpoint frequency (Cassin's Vireo recorded in Monterey County, California, 24 April by William Fish; Macaulay Library 22925). 
4a-d) in Cassin's and Plumbeous Vireo songs all overlapped broadly (Table 3). The average midpoint frequency of songs overlapped the least, with Cassin's Vireo songs being generally higher in frequency than Plumbeous Vireo songs (Figure 4e; Table 3). Of the first four characteristics, phrase length showed the least overlap; however, this was due to the greater incidence of doubled phrases in Cassin's songs ( 21 of 32, 66\%), while Plumbeous Vireo songs more rarely included doubled phrases (8 of 32, 25\%).

We suggest that many individual birds can be identified to species by means of a parametric model of the average midpoint frequency in each species (Figure 5), with varying trade-offs in utility and accuracy depending on the specific frequency chosen for identification purposes. For example, the average midpoint frequency for all Cassin's Vireo songs in our sample was $>3000 \mathrm{~Hz}$, or $>8.01$ on the log-transformed axis of Figure 5a, and a Gaussian curve fit to these data suggested that few Cassin's Vireos should be expected to sing songs with an average midpoint frequency $<3000 \mathrm{~Hz}$. If we were to classify every song with an average midpoint frequency $>3000 \mathrm{~Hz}$ as the song of a Cassin's Vireo, we would achieve a high rate of true positive classifications for this species (0.99), but at the expense of an unfortunate rate of false positives (0.59), because more than half of the Plumbeous Vireos we sampled also sang songs with an average midpoint frequency $>3000 \mathrm{~Hz}$ (Figure 5). Given our samples and modeling approach, the tradeoff between true and false positives for each species (Figure 6a) suggests that $3215 \mathrm{~Hz}$ is the optimal average midpoint frequency for maximizing the proportion of individuals (of both species) classified correctly (Figure 6b, Appendix at www.westernfieldornithologists.org/archive/V51/Pandolfino-Ray-vireos).

With $3215 \mathrm{~Hz}$ as the cutoff, our model categorizes over $84 \%$ of Cassin's Vireos (95\% CI $=74-91 \%)$ and $84 \%$ of Plumbeous Vireos (75-91\%) correctly, leaving $16 \%$ of Cassin's Vireos (9-25\%) classified incorrectly as Plumbeous Vireos and $16 \%$ of Plumbeous Vireos (9-26\%) classified incorrectly as Cassin's Vireos. Table 4 shows how the expected (mean) fraction of true and false positives varies for each species when different threshold frequencies are selected, and the Appendix offers an extended tabulation of these means and their 95\% confidence intervals (which illustrate how thresholds correspond to the fraction correctly identified). Leave-one-out cross-validation resulted in a similar optimum cutoff frequency (mean $=3215$, range 3205-3225) and classification success (84\% of Cassin's Vireos and 78\% of Plumbeous Vireos

TABLE 3 Comparison of Characteristics of Songs of the Cassin's and Plumbeous Vireos ${ }^{a}$

\begin{tabular}{lcccccc}
\hline & \multicolumn{2}{c}{ Cassin's } & & \multicolumn{2}{c}{ Plumbeous } \\
\cline { 2 - 3 } \cline { 5 - 6 } Character & Mean & StDev & & Mean & StDev \\
\hline Phrase length (sec) & 0.36 & 0.05 & & 0.31 & 0.03 \\
Song rate (phrases/min) & 33 & 10 & & 28 & 6 \\
Frequency-modulated phrases & $63 \%$ & $17 \%$ & & $52 \%$ & $19 \%$ \\
Doubled phrases & $12 \%$ & $14 \%$ & & $3 \%$ & $5 \%$ \\
Midpoint frequency $(\mathrm{Hz})$ & 3404 & 185 & & 3045 & 173 \\
\hline
\end{tabular}

${ }^{a_{n}}=32$ for each species. 

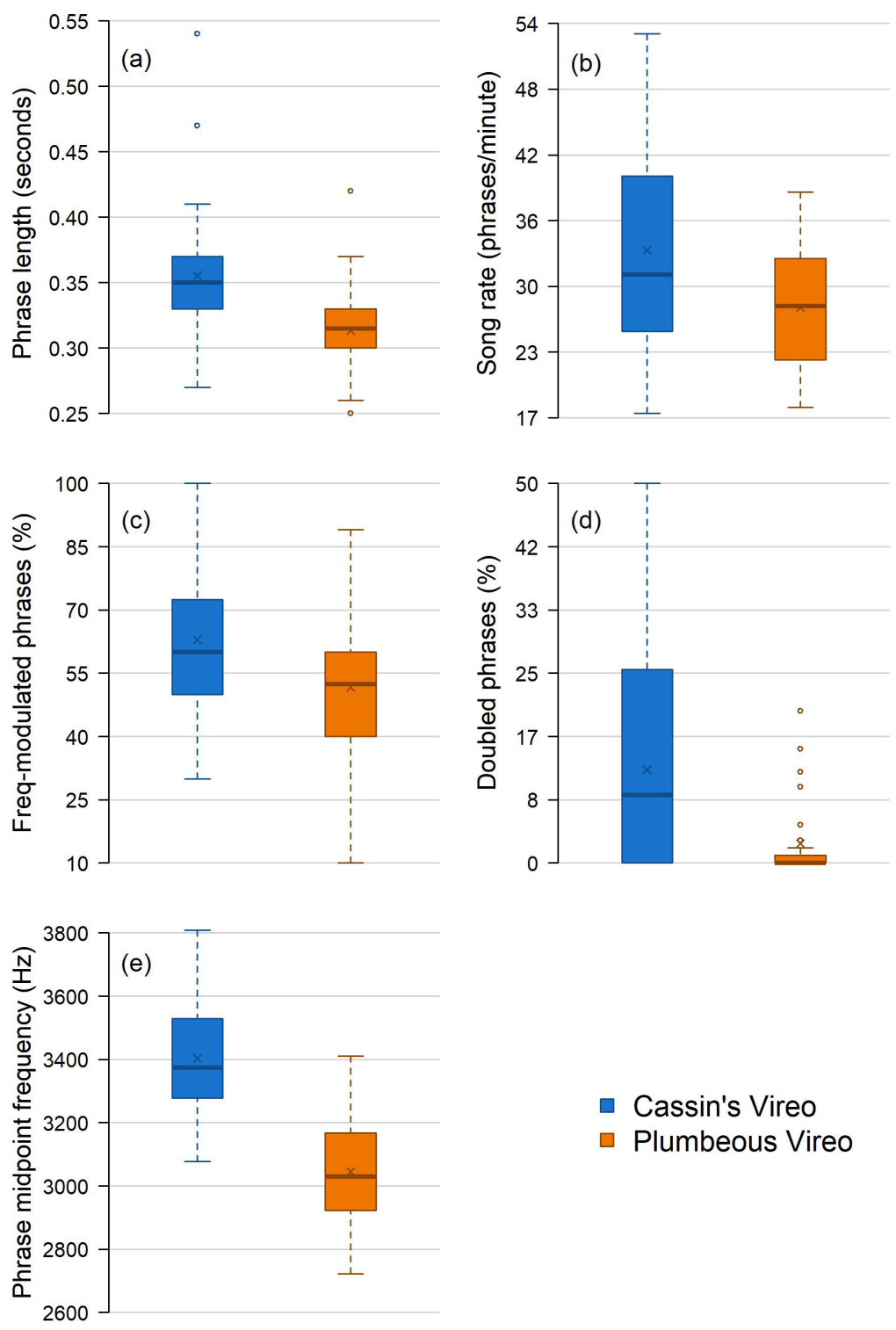

FIgure 4. Box plots comparing characteristics of the songs of the Cassin's and Plumbeous Vireos. (a) Phrase length, (b) song rate, (c) percent of phrases frequency modulated (buzzy), (d) percent of phrases doubled, (e) average of midpoint between highest and lowest frequency of phrases. Boxes, interquartile range; black line within boxes, median; whiskers, $3 \times$ interquartile range; circles, outlying values. 




Average midpoint frequency $(\ln )$

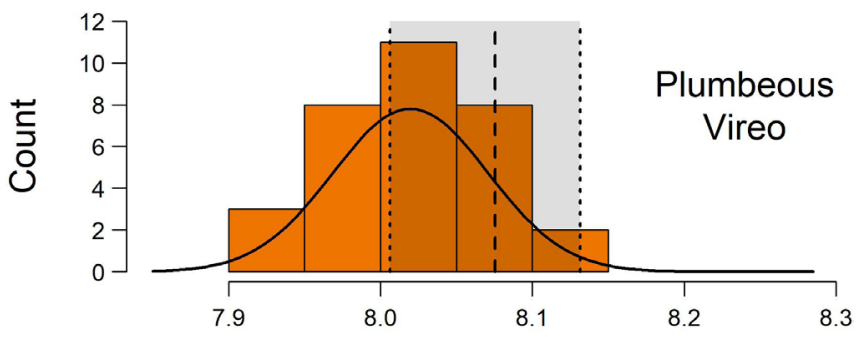

Average midpoint frequency (In)

Figure 5. Variation in the average midpoint frequency of songs of Cassin's and Plumbeous Vireos, shown as observed (histograms) and as modeled (curves). Vertical dashed lines indicate the natural logarithm $(\ln )$ of $3215 \mathrm{~Hz}$, the value for midpoint frequency cutoff that maximizes true positive identifications across both species. Vertical dotted lines indicate $\ln (3000)$ and $\ln (3400) \mathrm{Hz}$, used to exemplify dual cutoffs that increase true positive identifications for one or the other species (see text), at the expense of leaving a large proportion of individuals of each species unidentified (shaded regions).

were correctly identified under this model). In our logistic regression of true positive classifications, the success of categorization was not related to the number of song phrases analyzed per individual ( $\mathrm{df}=62 ; p=0.635$ ). The average difference between the two species was consistent regardless of the number of phrases analyzed (Figure 7). It is possible that using samples with a very large number of consecutive phrases $(>50)$ might produce a higher rate of successful classification, but we had too few samples in that range to draw a firm conclusion.

Two thresholds could be employed to reduce the proportion of misclassified birds, at the expense of leaving unidentified the birds with average midpoint frequencies that lie between the two values. For example, we could classify all birds with average midpoint frequencies $<3000 \mathrm{~Hz}$ as Plumbeous Vireos, and all those with average midpoint frequencies $>3400 \mathrm{~Hz}(>8.13$ on the log-transformed axis of Figure 5a) as Cassin's Vireos. With these values as thresholds, about $43 \%$ of Plumbeous Vireos would be identified, including about $41 \%$ true positives (below the $3000-\mathrm{Hz}$ threshold) and about $2 \%$ falsely 
TABLE 4 Expected Probability of Correct (True Positive) or Incorrect (False Positive) Identifications of the Plumbeous and Cassin's Vireos with Various Thresholds of Phrase-Midpoint Frequency in Songs ${ }^{a}$

\begin{tabular}{lccccc}
\hline & \multicolumn{2}{c}{$\begin{array}{c}\text { Fraction below threshold } \\
\text { identified as Plumbeous }\end{array}$} & & \multicolumn{2}{c}{$\begin{array}{c}\text { Fraction above threshold } \\
\text { identified as Cassin's }\end{array}$} \\
\cline { 2 - 3 } \cline { 5 - 6 } $\begin{array}{l}\text { Threshold } \\
\text { frequency }(\mathrm{Hz})\end{array}$ & $\begin{array}{c}\text { True } \\
\text { positive }\end{array}$ & $\begin{array}{c}\text { False } \\
\text { positive }\end{array}$ & & $\begin{array}{c}\text { True } \\
\text { positive }\end{array}$ & $\begin{array}{c}\text { False } \\
\text { positive }\end{array}$ \\
\hline 3000 & 0.406 & 0.01 & & 0.99 & 0.594 \\
3020 & 0.452 & 0.014 & & 0.986 & 0.548 \\
3040 & 0.498 & 0.02 & & 0.98 & 0.502 \\
3060 & 0.544 & 0.026 & & 0.974 & 0.456 \\
3080 & 0.59 & 0.034 & & 0.966 & 0.41 \\
3100 & 0.634 & 0.044 & & 0.956 & 0.366 \\
3120 & 0.676 & 0.056 & & 0.944 & 0.324 \\
3140 & 0.714 & 0.07 & & 0.93 & 0.286 \\
3160 & 0.752 & 0.088 & & 0.912 & 0.248 \\
3180 & 0.786 & 0.108 & & 0.892 & 0.214 \\
3200 & 0.816 & 0.132 & & 0.868 & 0.184 \\
3220 & 0.844 & 0.158 & & 0.842 & 0.156 \\
3240 & 0.868 & 0.188 & & 0.812 & 0.132 \\
3260 & 0.89 & 0.22 & & 0.78 & 0.11 \\
3280 & 0.91 & 0.254 & & 0.746 & 0.09 \\
3300 & 0.926 & 0.292 & & 0.708 & 0.074 \\
3320 & 0.94 & 0.332 & & 0.668 & 0.06 \\
3340 & 0.952 & 0.372 & 0.628 & 0.048 \\
3360 & 0.96 & 0.416 & 0.584 & 0.04 \\
3380 & 0.97 & 0.458 & 0.542 & 0.03 \\
3400 & 0.976 & 0.502 & 0.498 & 0.024 \\
\hline
\end{tabular}

${ }^{a}$ See Appendix at archive.westernfieldornithologists.org/V51/Pandolfino-Ray for additional values, $95 \%$ confidence intervals, and values with the two species considered simultaneously.

identified as Cassin's Vireo (above the 3400-Hz threshold), leaving about 57\% of Plumbeous Vireos not identified at all (Figure 5, Appendix). Similarly, about $51 \%$ of Cassin's Vireos would be identified, including about $50 \%$ true positives (above the $3400-\mathrm{Hz}$ threshold) and about $1 \%$ falsely identified as the Plumbeous Vireo (below the $3000-\mathrm{Hz}$ threshold), leaving $49 \%$ of Cassin's Vireos unidentified (Figure 5, Appendix). If one raises the threshold for Plumbeous or lowers the threshold for Cassin's, more birds will be identified, but at the cost of higher rates of misidentification. To ensure that at least $95 \%$ of all birds identified as Plumbeous Vireos are true positives, there must be no more than $5 \%$ false positives. In this case, our analysis suggests a midpoint frequency cutoff of $3050 \mathrm{~Hz}$ (Appendix), which results in fewer than $5 \%(95 \%$ $\mathrm{CI}=1.0-4.8 \%)$ false identifications of Cassin's Vireos as Plumbeous Vireos. To ensure $90 \%$ or $99 \%$ true positives for the Plumbeous Vireo, our analysis suggests cutoffs of 3110 or $2940 \mathrm{~Hz}$, respectively (Appendix). To ensure $90 \%$, $95 \%$, or $99 \%$ true positives for Cassin's Vireo, our analysis suggests cutoffs of 3340,3410 , or $3540 \mathrm{~Hz}$, respectively (Appendix). 


\section{DISCUSSION}

Whenever a single historical species is broken up, issues of range limits and identification of birds out of range become more consequential to birders and to ornithologists. When the species are easily differentiated in the field visually or through vocalizations, resolving range limits and identifying wayward birds is usually straightforward. In the case of the Solitary Vireo complex, the three species can be differentiated visually in the field when in relatively fresh plumage. However, distinguishing the Blue-headed from Cassin's or Cassin's from the Plumbeous can be difficult when the birds are in faded spring/summer plumage (Heindel 1996, Heindel and Heindel 2004, Sibley 2014). Heindel (1996) noted that, regardless of plumage wear, normal individual variation and the quality of light during observation renders field identification of some birds impossible.

In many field identification challenges (e.g., Empidonax flycatchers), vocalizations are helpful. In the case of this vireo complex, some sources suggest that a slower rate of song delivery and fewer frequency-modulated (buzzy) phrases allow the Blue-headed to be distinguished from the other two species (James 1981, Heindel and Heindel 2004, Sibley 2014, Dunn and Alderfer 2017, Pieplow 2017). Distinguishing Cassin's from the Plumbeous Vireo by song is considered more difficult, but some authors have suggested that the song's frequency and/or the proportion of buzzy phrases may be useful (James 1981, Sibley 2014, www.allaboutbirds.org/guide/Cassins_Vireo/ sounds). However, only James (1981) showed any data, and those data were based on very few samples. Indeed, Floyd (2008), Dunn and Alderfer (2017), and Pieplow (2019) cautioned that differences in song may not be useful for differentiation between those species.

From the average midpoint frequency most of these vireos can be identified as the correct species. However, the broad overlap in midpoint frequency means that one must weigh various factors in choosing the criteria for identification. If one wants to identify Cassin's Vireos confidently from a sample of unknowns, one should use a higher frequency as the threshold (3410 $\mathrm{Hz}$ for at least 95\% true positives), though it will leave more birds unidentified. Conversely, a lower threshold is appropriate if the goal is to confirm Plumbeous Vireos (3050 Hz for at least 95\% true positives). Given a clear recording of several consecutive song phrases, the Appendix at https:// archive.westernfieldornithologists.org/archive/V51/Pandolfino-Ray-vireos can be used to quantify confidence in species identity.

Sampling songs from the regions where there is uncertainty about the occurrence of these species might allow one to resolve these range issues. However, analyses of these songs may be equivocal if the two taxa are sympatric in these areas. Exposure of birds of one species to the song of the other during their song-learning period may result in songs whose midpoint frequency differs from that found outside the zone of sympatry. Also, such areas may produce some hybrid individuals that could also make the data difficult to interpret. Ideally, such studies would couple recording of song with visual identification of the individual through photographs and/or collection of specimens. 

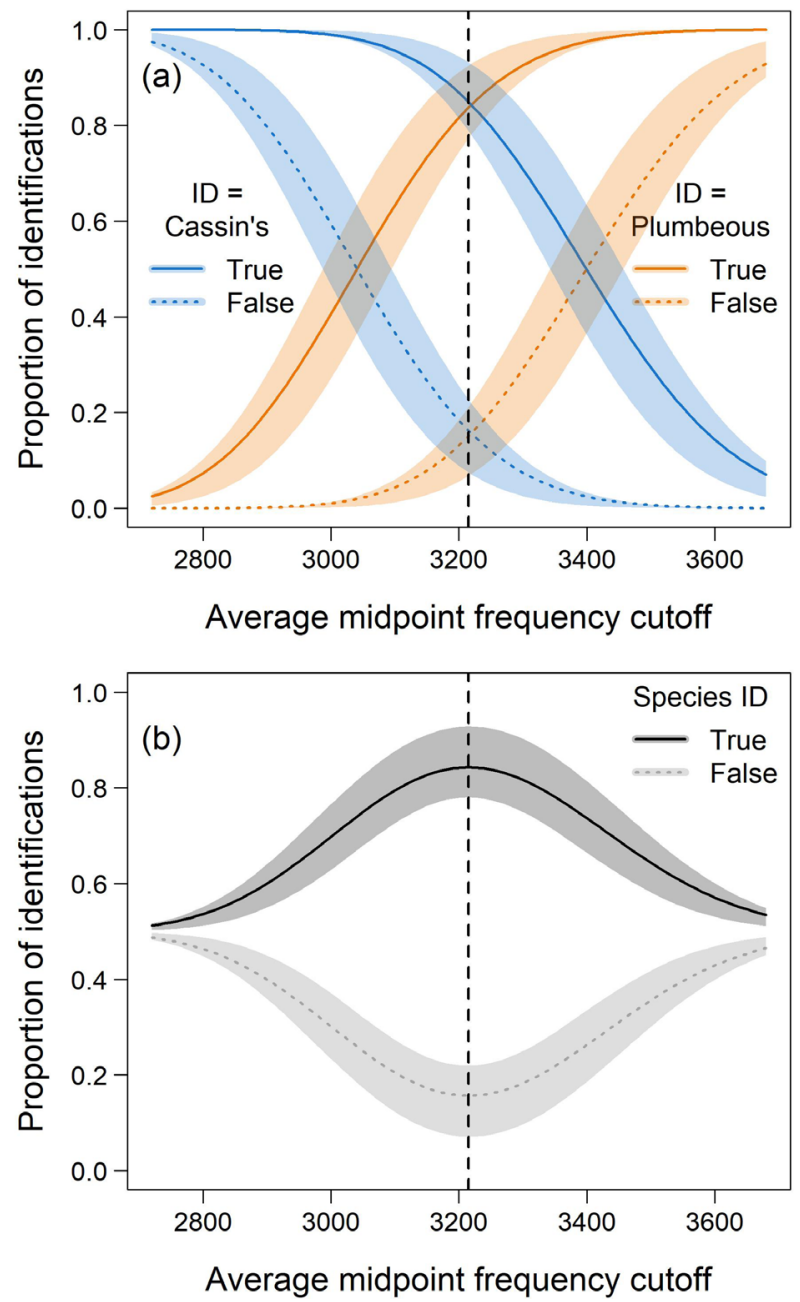

FIgURE 6. (a) Proportion of species identifications expected to be correct (true positive, solid lines) and incorrect (false negative, dotted lines) given the models in Figure 5 and a range of potential thresholds in average frequency that might be used to distinguish between the Cassin's and Plumbeous Vireos. (b) Proportion of all identifications expected to be correct (solid line) or incorrect (dotted line) on the basis of these models. Shaded regions represent parametric $95 \%$ confidence intervals, and the dashed vertical lines represent the optimal cutoff frequency $(\sim 3215 \mathrm{~Hz})$ for distinguishing Cassin's from Plumbeous Vireos on the basis of the songs sampled. 


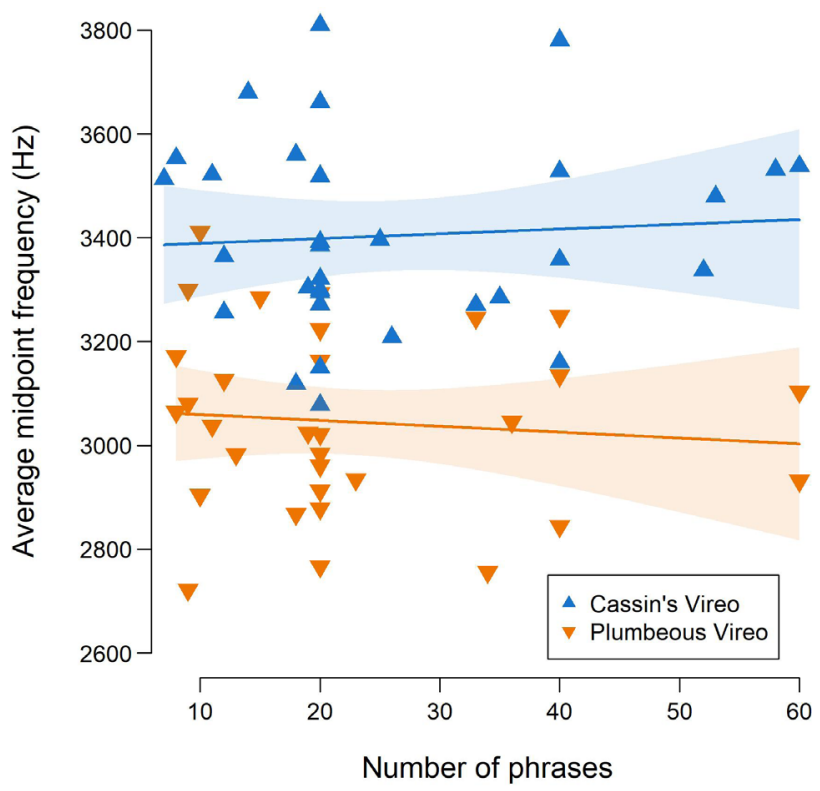

FIGURE 7. Linear regressions (and 95\% confidence intervals) of the average midpoint frequency on the number of song phrases used to estimate average midpoint frequency, for Cassin's Vireo (blue upright triangles) and Plumbeous Vireo (orange inverted triangles).

\section{ACKNOWLEDGMENTS}

We thank all the recordists of the songs we used (Arthur Allen, Michael Andersen, Tim Avery, Harriette Barker, Lance Benner, David Bradley, Tayler Brooks, Eric Cannizzaro, L. Irby Davis, Eric DeFonso, Jeff Dyck, William Fish, Stuart Fisher, Ted Floyd, William Gunn, Don Jones, Geoffrey Keller, Gabriel Leite, Bob McGuire, David Moyer, Scott Olmstead, Luke Owens, Chris Parrish, Nathan Pieplow, Micah Riegner, Sue Riffe, Mark Robbins, Andrew Spencer, Robert Stein, Brian Sullivan, Richard Webster, Bobby Wilcox, and Matt Wistrand), as well as Xeno-canto and the Macaulay Library for maintaining their extensive collections and making them available to us. Comments and suggestions from Ted Floyd, Daniel D. Gibson, Philip Unitt, and an anonymous reviewer allowed us to improve the focus and clarity of the manuscript. This is contribution number 665 of The Institute for Bird Populations.

\section{LITERATURE CITED}

Borror, D. J. 1972. Yellow-green Vireo in Arizona, with notes on vireo songs. Condor 74:80-86; doi.org/10.2307/1366452.

Dunn, J. L., and Alderfer, J. A. 2017. National Geographic Field Guide to the Birds of North America. Natl. Geogr. Soc., Washington, D.C.

Faulkner, D. W. 2010. Birds of Wyoming. Roberts and Co., Greenwood Village, CO. Floyd, T. 2008. Field Guide to the Birds of North America. HarperCollins, New York. 
Goguen, B., and Curson, D. R. 2012. Plumbeous Vireo (Vireo plumbeus), in The Birds of North America (A. F. Poole, ed.), no. 366, version 2.0. Cornell Lab Ornithol., Ithaca, NY; doi.org/10.2173/bna.366.

Hedley, R. W. 2016. Composition and sequential organization of song repertoires in Cassin's Vireo (Vireo cassinii). J. Ornithol. 157:13-22; doi.org/10.1007/s10336015-1238-x.

Heindel, M. T. 1996. Field identification of the Solitary Vireo complex. Birding 28:459-471.

Heindel, T., and Heindel, J. 2004. The Solitary Vireo complex in Inyo County. Eastern Sierra Wave 22:3.

James, R. D. 1981. Factors affecting variation in the primary song of North American Solitary Vireos (Aves: Vireonidae). Can. J. Zool. 59:2001-2009; doi.org/10.1139/ z81-272.

Johnson, N. K. 1995. Speciation in vireos. I. Macrogeographic patterns of allozymic variation in the Vireo solitarius complex in the contiguous United States. Condor 97:903-919; doi.org/10.2307/1369530.

Marks, J. S., Hendricks, P., and Casey, D. 2016. Birds of Montana. Buteo Books, Arrington, VA.

Martindale, S. 1980. A numerical approach to the analysis of Solitary Vireo songs. Condor 82:199-211; doi.org/10.2307/1367478.

Pieplow, N. 2017. Field Guide to Bird Sounds of Eastern North America. Houghton Mifflin Harcourt, Boston.

Pieplow, N. 2019. Field Guide to Bird Sounds of Western North America. Houghton Mifflin Harcourt, Boston.

Sabbekoorn, H., and Smith, T. B. 2002. Bird song, ecology, and speciation. Philos. Trans. Royal Soc. London B 357:493-503; doi.org/10.1098/rstb.2001.1056.

Sibley, D. A. 2014. The Sibley Guide to Birds, $2^{\text {nd }}$ ed. Knopf, New York.

Accepted 13 May 2020 


\title{
NESTING BIOLOGY OF URBAN COOPER'S HAWKS IN ALAMEDA COUNTY, CALIFORNIA
}

\author{
RALPH V. PERICOLI, Golden Gate Raptor Observatory, Golden Gate National \\ Parks Conservancy, Building 1064, Fort Cronkhite, Sausalito, California 94965 \\ EMMA L. KARSTEN, Hamilton College, Environmental Studies Program, 198 \\ College Hill Rd, Clinton, New York 13323
}

ALLEN M. FISH, Golden Gate Raptor Observatory, Golden Gate National Parks Conservancy, Building 1064, Fort Cronkhite, Sausalito, California 94965

CHRISTOPHER W. BRIGGS, Colgate University, 13 Oak Dr., Hamilton, New York 13346; cbriggs@colgate.edu

ABSTRACT: In recent decades Cooper's Hawks have successfully colonized urban landscapes, where there may be ample prey but also a greater prevalence of disease in their prey. We searched for nesting Cooper's Hawks in and around Berkeley, California, from 2002 to 2010 , locating 95 nests, 89 of which successfully fledged at least one nestling. On average, each nest produced 3.6 fledglings. We evaluated the possible effects of the protozoan parasite Trichomonas gallinae on Cooper's Hawk reproduction from the proportion of potential prey items brought to Lindsay Wildlife Experience that tested positive for the parasitic disease. We did not find a correlation between T. gallinae in potential prey species and nest success (i.e., if the nest fledged any offspring) or reproductive success (i.e., number of fledglings produced). Similarly, we did not find a relationship between reproductive success and distance to parks or percent of impervious surface within $500 \mathrm{~m}$ of the nest. The high reported rates of reproduction and high densities of Cooper's Hawk in Berkeley and neighboring Albany suggest a robust population, and we did not find evidence that T. gallinae influences its reproductive success.

The Cooper's Hawk (Accipiter cooperii) is a common woodland hawk that often focuses on birds as prey (Rosenfield et al. 2019b). While it nests throughout the United States and boreal Canada in a variety of tree species in dense woods (Rosenfield et al. 2019b), in recent decades it has adapted to urban habitats (Boal and Mannan 1998). Cooper's Hawks in more urban environments differ in behavior and nesting habitats (Mannan and Boal 2000, Estes and Mannan 2003, Stout et al. 2007, Chiang et al. 2012, Millsap 2018). In southern California, for example, rural Cooper's Hawks typically use oak and riparian woodland, whereas their urban counterparts use parks and ornamental plantings (Chiang et al. 2012). Urban pairs are also more tolerant of human approaches to the nest and are bolder than their nonurban counterparts (Boal and Mannan 1999).

Urban habitats may not be productive or self-sustaining for Cooper's Hawks, acting as population sinks, which rely on immigration to maintain stable populations (Reynolds 1983, Bosakowski et al. 1993). However, some urban environments may actually confer advantages on the hawk populations, such as increased prey populations (Millsap 2018). In contrast, Mannan et al. (2008) and Boal et al. (1998) found negative effects of urbanization in Tucson, Arizona, which may function as a population sink for Cooper's Hawks, where populations need to be replenished by immigration from outside populations. Specifically, in doves, the primary prey of urban Cooper's Hawks in Tucson, they found a high prevalence of disease caused by 
the protozoan parasite Trichomonas gallinae. As a result, there was a much higher rate of T. gallinae infection in urban than in exurban hawk nestlings (85\% versus 9\%, respectively; Boal et al. 1998). Boal et al. (1998) hypothesized that a greater availability and abundance of prey in Tucson draws Cooper's Hawks to the city, where adults may deliver twice as much prey to nests as do rural Cooper's Hawks (Estes and Mannan 2003). However, the presence of T. gallinae in the abundant urban prey impairs the hawks' productivity (Boal et al. 1998).

Still, studies of Cooper's Hawks in other urban areas indicate that some populations may be well adapted to increased urbanization (Stout and Rosenfield 2010, Chiang et al. 2012, Millsap 2018). For example, in Orange County, California, urban-nesting Cooper's Hawk pairs produce significantly more young on average than do non-urban pairs (Chiang et al. 2012). Similarly, Stout et al. (2007) found that urban Milwaukee, Wisconsin, was not an ecological sink for Cooper's Hawk, citing long-term high reproduction rates, repeated re-occupancy of nest sites, and confirmed recruitment from within the population. In central New Mexico urban Cooper's Hawks also represent a source population instead of a sink, and urban hawks outcompete exurban hawks through their ability to overwinter in the city instead of migrating (Millsap 2018).

Given differences between populations in reproductive rates in urban areas, we examined the nesting biology of an urban Cooper's Hawk population in the city limits of Berkeley and Albany in Alameda County, California. We excluded San Francisco baylands west of Interstate 80 and largely inaccessible University of California lands uphill from the university's campus. The resulting study area was roughly rectangular, measuring 5.9 by $4.7 \mathrm{~km}$ and covering approximately 2780 ha.

During a long-term study of nesting Cooper's Hawks, we assessed apparent nest success (i.e., nest success not corrected for biases in missing nests that failed earlier in the season; Mayfield 1961), nest productivity, nest location, nest density, and habitat preferences. Additionally, we examined long-term data on the prevalence of T. gallinae in potential prey species brought to a local wildlife-rehabilitation center to determine if the hawk's annual productivity in Berkeley was related to the rates of the parasite's incidence in potential prey, as it was in Tucson (Boal et al. 1998). We hypothesized that the prevalence of T. gallinae should depress the average yearly productivity of Cooper's Hawk nests in Berkeley. We also predicted that nesting territories with less vegetation and more impervious surfaces should be less productive because of their greater abundance of prey possibly infected with T. gallinae.

\section{METHODS}

In February 2002, we recruited volunteers from the Golden Gate Raptor Observatory, each with a minimum of three years of experience in counting or banding accipiters, to locate and monitor Cooper's Hawk nests in Berkeley and Albany. In subsequent years, we added experienced birders as needed to cover the study area. Intensive nest searches and monitoring continued annually through the breeding season of 2010. Each volunteer was trained in how to identify and monitor Cooper's Hawk nest structures and plucking perches 
(i.e., locations where hawks regularly remove feathers and other inedible parts of prey). We located potential nest structures prior to deciduous trees leafing out and monitored those structures through the breeding season (Figure 1). In addition, we monitored for signs of nesting activity (e.g., calling adults, flight displays, etc.) and surveyed for alternate nests (i.e., other potential nests within a nesting territory; Steenhof et al. 2017).
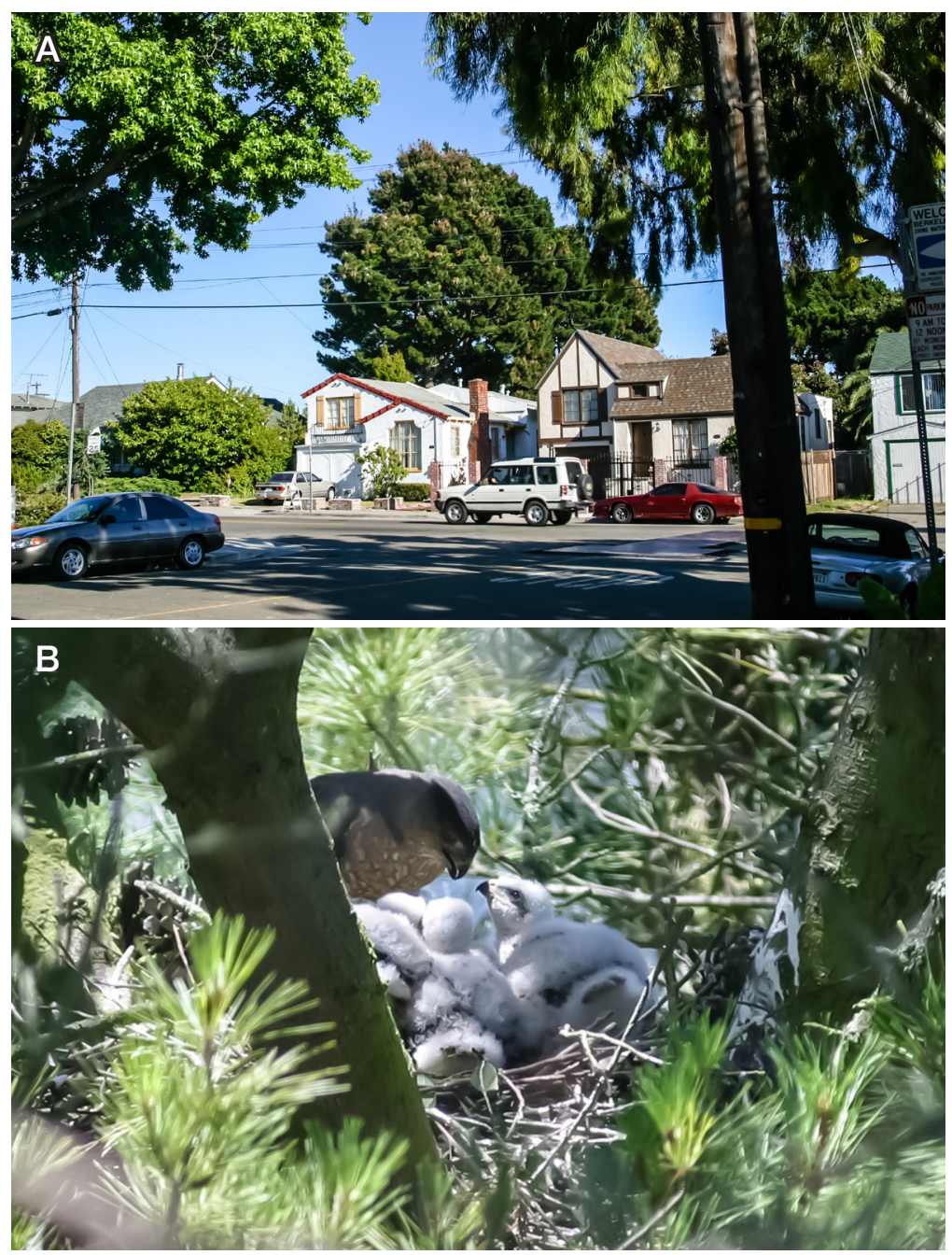

Figure 1. (A) Typical Cooper's Hawk nest tree, a Monterey Pine, Pinus radiata, along a Berkeley street. (B) Adult female Cooper's Hawk attending five 2-week-old nestlings. 
Once a nest was located we mapped its location and monitored it approximately once every two weeks, visually confirming activity at the nest, counting offspring whenever possible, or noting no activity after approximately one hour. We used binoculars and spotting scopes to count the number of offspring from a safe distance, and assumed a nest had failed when there was no activity at it on two consecutive visits each representing observation for approximately one hour. All counts of nestlings were confirmed by a second experienced observer. Nests were considered successful if any nestling was able to start branching (i.e., leaving the nest and perching on adjacent limbs).

We classified nests as being found within a park, on the University of California campus, along a city street, or in a residential back yard. We identified the species of tree supporting each nest, and calculated the distance to the next nearest active nest each year. We used ArcGIS to measure the percent of impervious surfaces such as cement and asphalt (available from https://www. cityofberkeley.info/gisportal/). We estimated the percent cover of vegetation in each pair's home range, defined as circle of radius $0.5 \mathrm{~km}$ around its nest, visually by using aerial imagery from Google Earth.

We estimated the prevalence of $T$. gallinae in potential prey species (i.e., Passeriformes and Columbidae) from its incidence in 3439 wild birds brought to the Lindsay Wildlife Experience in Walnut Creek, California, from 2002 to 2010. Typically, these birds came from Alameda and Contra Costa counties, but some were from farther away. Using a logistic regression $(P>0.05$ for all comparisons), we did not find a difference in proportion of individuals affected across counties, so we combined all data. We recorded physical symptoms, such as large caseous lesions on the mouth and throat, when they were consistent with T. gallinae. In addition to measuring the overall proportion of birds infected each year, we calculated the percent of infected birds of each species for each year as an index of disease risk for each year of the study. We selected four species documented as Cooper's Hawk prey in previous studies that were also common in the sample of birds received at Lindsay Wildlife Experience-the Mourning Dove (Zenaida macroura), House Finch (Haemorhous mexicanus), and Lesser (Spinus psaltria) and American (S. tristis) goldfinches-and from the prevalence of T. gallinae in these species calculated a single variable by pooling all samples. While we examined individual birds showing visible signs of T. gallinae, we also tested a subset of individuals by examining swabbed cloanal cells under a microscope. Annual measures of the proportion of individuals showing macroscopic symptoms of T. gallinae and those positive when swabbed were highly correlated (Pearson correlation coefficient $=0.84, t_{7}=4.0, P=0.005$ ).

We examined nest success and productivity with generalized linear mixed models, using the package lme4 (Bates et al. 2015) in R 3.5.3 (R Core Team 2017). Territory and year represented repeated measures within the logistic and quasi-Poisson families, respectively. For each response variable we examined tree species, year, percent impervious cover, and percent vegetation within a territory. We used backwards stepwise selection to find the most parsimonious model, and assumed $\alpha=0.05$ for all analyses.

We used a simple linear regression to examine the relationship between average annual productivity across the study area and prevalence of T. gallinae. We also used a simple linear regression to examine the relationship 
between apparent annual nest success across the study area and prevalence of the parasite.

\section{RESULTS}

From 2002 through 2010 we located 95 Cooper's Hawks nests in Berkeley and Albany, averaging 10.6 nests located each year of the study (Figure 2). Of these nests, $89(94 \%)$ were successful in producing at least one fledgling (Table 1). Apparent nest success was 100\% for all years except 2003 (75\%) and $2009(63 \%)$. Mean productivity $( \pm$ SD) across the study was $3.4 \pm 1.2$ fledglings/nest, and productivity of successful nests was $3.6 \pm 0.8$ fledglings/ nest. The largest number of nests $(n=36 ; 37 \%)$ was found in trees along (i.e., within $3 \mathrm{~m}$ of) streets and sidewalks, with the remainder being found in local parks $(n=25)$, on the University of California campus $(n=22)$, or in the back yards of homes $(n=13)$. The nesting period was primarily February through the end of June (Table 2). Nests were most commonly found in ash trees (Fraxinus spp.; $n=21$ ), but also in eucalyptus (Eucalyptus spp.; $n=14$ ), American elm (Ulmus americana; $n=13$ ), and Monterey pine (Pinus radiata; $n=13$ ), among other less important species.

On average, nests had a large proportion of impervious surface $(89.8 \%$ $\pm 10.9 \%$ ) within a radius of $0.5 \mathrm{~km}$. In addition, nests tended to be closely spaced; the average distance to the nearest neighbor was $999.7 \mathrm{~m} \pm 380.5 \mathrm{~m}$. There was no relationship between category of nest location (i.e., park, campus, backyard, or street), percent impervious surface in a territory, amount

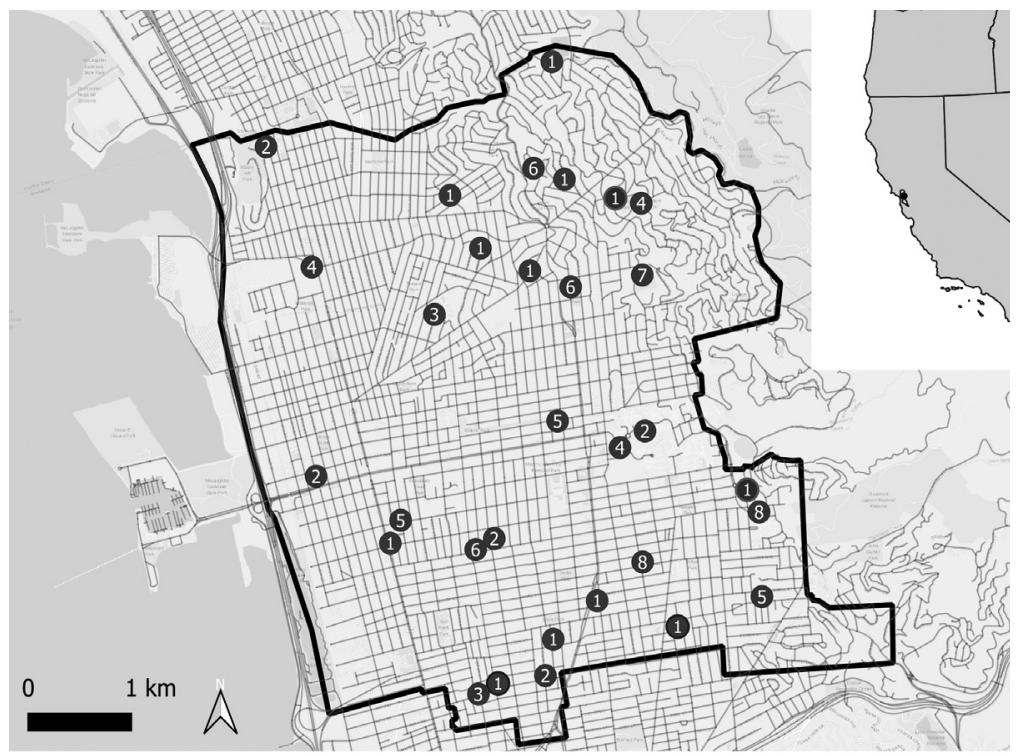

FiguRe 2. Nest sites of Cooper's Hawk in the city of Berkeley from 2002 through 2010. Numbers indicate the number of years a nest was found within a radius of $50 \mathrm{~m}$. 
TABle 1 Annual Counts, Productivity, and Density of Cooper's Hawk Nests in Berkeley, California, and Prevalence of Trichomonas gallinae in Possible Prey Admitted to Lindsay Wildlife Experience

\begin{tabular}{lcccccc}
\hline & $\begin{array}{c}\text { Total } \\
\text { nests }\end{array}$ & $\begin{array}{c}\text { Successful }_{\text {nests }^{a}} \\
\text { productivity }^{b}\end{array}$ & $\begin{array}{c}\text { Tverage } \\
\text { productivity/ } \\
\text { nest }\end{array}$ & $\begin{array}{c}\text { Density } \\
\text { (ha/pair) }\end{array}$ & $\begin{array}{c}\text { T. gallinae } \\
\text { prevalence } \\
\left(\% \text { of } n^{c}\right)\end{array}$ \\
\hline 2002 & 12 & 12 & 40 & 3.3 & 232 & $1.4(521)$ \\
2003 & 12 & 9 & 36 & 3.0 & 309 & $1.7(527)$ \\
2004 & 14 & 14 & 53 & 3.8 & 199 & $1.7(236)$ \\
2005 & 10 & 10 & 41 & 4.1 & 278 & $4.3(369)$ \\
2006 & 12 & 12 & 39 & 3.3 & 232 & $4.2(391)$ \\
2007 & 11 & 11 & 41 & 3.7 & 253 & $2.0(333)$ \\
2008 & 9 & 9 & 32 & 3.7 & 309 & $3.0(344)$ \\
2009 & 8 & 5 & 16 & 3.2 & 397 & $3.6(376)$ \\
2010 & 7 & 7 & 25 & 3.6 & 397 & $3.5(331)$ \\
Average & 10.6 & 9.9 & 36.2 & 3.5 & 289.6 & $2.8(281)$ \\
\hline
\end{tabular}

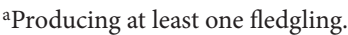

${ }^{b}$ Number of nestlings fledged.

Number of individuals of prospective prey tested.

of vegetation within a territory, or distance to nearest neighbor with either nest success or productivity $(P>0.07$ for all relationships).

The prevalence of T. gallinae in birds brought to Lindsay Wildlife Experience ranged from 1.4 to $4.3 \%$ over the course of the study (Table 1). There was no relationship between this prevalence in any prey species and annual apparent success of Cooper's Hawk nests $(P>0.42$ for all relationships, $n=$ 9). Similarly, there was no relationship between prevalence of T. gallinae and average annual productivity across the study site $(P>0.30$ for all relationships, $n=9$; Figure 3 ).

TABLE 2 Phenology of Cooper's Hawks Nesting in Berkeley, California

\begin{tabular}{lccccc}
\hline & Pair on territory & & & & \\
& Nest building & & Observed & & \\
incubation & Hatching date & Branch date $^{c}$ \\
\hline 2002 & 13 Feb-20 Apr & 27 Feb-22 Mar & 30 Mar-19 Apr & 6-23 May & 4-28 Jun \\
2003 & 30 Jan-7 Mar & 21 Feb-8 Apr & 7-27 Apr & 8 May-10 Jun & 15 Jun-9 Jul \\
2004 & 11 Jan-27 Feb & 28 Feb-14 Mar & 2-17 Apr & 5-28 May & 10-28 Jun \\
2005 & 1-16 Mar & 7-10 Mar & 10-18 Apr & 20 May-8 Jun & 11-30 Jun \\
2006 & 7-24 Mar & 25 Feb-14 Apr & 10 Apr-12 May & 17 May-13 Jun & 14-27 Jun \\
2007 & 1 Feb-23 Mar & 4 Feb-28 Apr & 14-28 Apr & 7-26 May & 15 Jun-2 Jul \\
2008 & 10 Feb-23 Mar & 7 Mar-6 Apr & 6-19 Apr & 11-27 May & 17-28 Jun \\
2009 & 2 Feb-6 Mar & 19 Feb-7 Mar & 13-19 Apr & 26 May-7 Jun & 17-26 Jun \\
2010 & 6 Feb-23 Mar & 6 Feb-24 Mar & 5-26 Apr & 15 May-4 Jun & 19 Jun-2 Jul \\
Range & 11 Jan-20 Apr & 4 Feb-28 Apr & 30 Mar-12 May & 5 May-13 June & 4 Jun-9 Jul \\
\hline
\end{tabular}

${ }^{a}$ When pairs were observed defending, using alarm calls, or displaying (e.g., fanned-tail display).

${ }^{b}$ Defined by observations of adult hawks carrying materials to a nest structure.

${ }^{c}$ Date on which young began moving among the branches of the nest tree. 


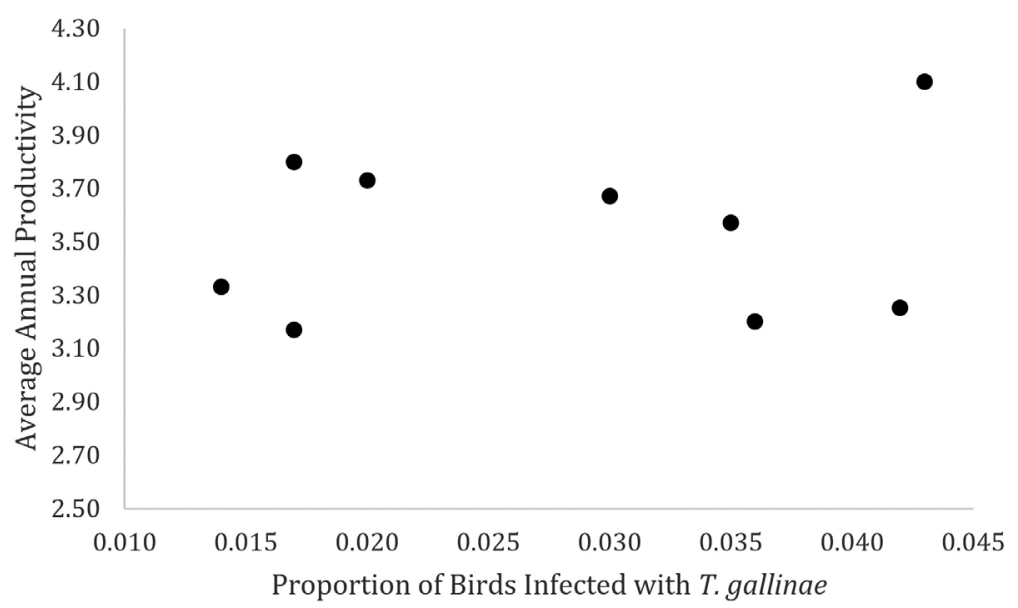

FIGURE 3. Relationship between nest productivity of Cooper's Hawks in Berkeley and prevalence of Trichomonas gallinae in four common potential species of prey brought into Lindsay Wildlife Experience in Walnut Creek, California, from 2002 through 2010. Each point represents the incidence in the Mourning Dove, House Finch, American Goldfinch, and Lesser Goldfinch pooled over one year.

\section{DISCUSSION}

The prevalence of infection with T. gallinae in potential prey did not influence Cooper's Hawks' nest success or productivity in our Alameda County study area. The high rate of productivity and lack of apparent deleterious effect of diseased prey on reproduction indicates that Berkeley has the potential to be a population source (i.e., population from which there is net emigration) for Cooper's Hawk, in contrast to Tucson (Boal et al. 1998; but see Mannan et al. 2008). Nevertheless, T. gallinae has been found in Cooper's Hawks within the study area (Lindsay Wildlife Experience, unpubl. data). While we found no relationship between disease prevalence in prey and hawk reproduction, we did not test hawk nestlings or fledglings for T. gallinae. Rather, our data on the disease's prevalence came only from tests on birds brought to a local wildlife hospital. Many birds admitted were not swabbed for T. gallinae, which could have affected the results for disease prevalence. Additionally, we assumed that the birds brought to Lindsay Wildlife Experience reflected the relative prevalence of the disease in the local region, and should therefore reflect the local exposure of Cooper's Hawks. In addition, with only six monitored nests failing and reproductive success very high throughout the 10 years of the study, the effects of disease could be difficult to detect, and more targeted monitoring to clarify the effects of T. gallinae on this population is appropriate.

The average productivity of 3.6 fledglings per nest per laying pair is high compared to other urban Cooper's Hawk populations, and similar to the averages of 4.1 fledglings in Oshkosh, Wisconsin, and 3.5 fledglings in Stevens Point, Wisconsin (Rosenfield et al. 2019a). Stout et al. (2010) found an aver- 
age of 2.6 nestlings per laying pair of urban Cooper's Hawks in Milwaukee, Wisconsin, while Boal (1997) found an average of 3.1 nestlings per laying pair in Tucson, Arizona. Additionally, the Berkeley population's nest-success rate of $94 \%$ is among the highest reported for urban Cooper's Hawks, exceeding the rates of $84 \%$ around Tucson (Mannan et al. 2008), $47 \%$ in urban Tucson (Boal and Mannan 1999), and 65\% in Milwaukee (Stout et al. 2010). While we measured only apparent nest success and therefore are likely overestimating true nest success across the study (Mayfield 1961), the studies with which we compare our rates similarly used apparent nest success. Future work should focus on estimating the Berkeley population's rate of daily nest survival to determine if our relatively small sample sizes could be influencing detection and causing more bias in our estimate of nest success.

Not only are its rates of nesting success and productivity high, the density of the Berkeley population of Cooper's Hawk is high. An average density of 1 nest per 290 ha over the course of the study (and 1 nest per 199 ha in 2004) is among the highest reported for Cooper's Hawk. Densities of Cooper's Hawk nests range from 1 per 671 to 2326 ha in the western U.S. (Reynolds 1989) and 1 per 331 to 5000 ha in eastern states (Rosenfield et al. 1991). In comparison to the densities of other urban Cooper's Hawk populations studied-1 nest per 101 ha in Albuquerque, New Mexico (Millsap 2018), 1 nest per 437 ha in Tucson (Boal and Mannan 1998), 1 nest per 272 ha in Stevens Point, Wisconsin (Rosenfield et al. 1995), and 1 nest per 238 ha in Oshkosh, Wisconsin (Rosenfield et al. 2019a) - that of the Berkeley population is also one of the highest observed. Despite this high density, our estimate is likely biased low because we could not access many private yards, and detection of nests was likely not $100 \%$.

These high rates of nest success and productivity and high population density indicate that the city of Berkeley is good-quality habitat for Cooper's Hawk. This population supports the hypothesis of Rosenfield et al. (1995) that urban areas allow for denser Cooper's Hawks populations than do rural areas. Urban areas have been shown to have elevated abundances of prey (Chamberlain et al. 2009). The greater density of prey in urban areas (Bird et al. 1996, Boal and Mannan 1998) may be responsible for the high density of Berkeley's Cooper's Hawk population.

Such high densities of prey may mean that nesting Cooper's Hawks do not need natural areas to find adequate prey. We found no relationship between reproduction and the extent of impervious surface within a territory, which is consistent with previous studies' findings that human disturbance and land use does not seem to affect Cooper's Hawk's nest-site selection (Boal and Mannan 1998, Rullman and Marzluff 2014). For example, Rullman and Marzluff (2014) found that Cooper's Hawks seemed to prefer areas of mixed vegetation and urban surfaces over wooded areas, which can also explain the high density of Cooper's Hawks in the urban environment of Berkeley.

As these data have shown, the city of Berkeley constitutes an attractive and successful breeding habitat for Cooper's Hawks. Despite these indications of a healthy population, more work needs to be done to determine if the Berkeley area serves as a population source or sink. For example, other factors, such as low rates of survival of juveniles or adults, could mean that this population is also a sink despite its high productivity. 
Additionally, the diet of Berkeley Cooper's Hawks should be compared to that of other urban Cooper's Hawks, and the role of prey abundance and diversity in the high success rate of the Berkeley population should be considered. By further understanding the features that promote occupancy of Cooper's Hawks, we can better understand the role of urban environments in source/sink dynamics and how disease may play a role in that process.

Additionally, this study demonstrates the ability of volunteers to locate, monitor, and collect data on nesting Cooper's Hawks, guided by supervising biologists. Community scientists successfully located and monitored 96 Cooper's Hawks nests over 9 years in an urban setting and recorded the birds' performance in breeding. These data provide evidence for a robust raptor population in an urban environment, with higher densities and reproductive success than has been previously documented in the literature. The study also demonstrates the ability of community scientists to maintain long-term studies and collect meaningful data.

\section{ACKNOWLEDGMENTS}

This study could not have been conducted without the nest searching and monitoring by the dozens of volunteer community scientists of the Golden Gate Raptor Observatory (GGRO). Great thanks to Anne Ardillo, Laura Baker, Muki Belliappa, Ande Bennett, Christopher Berner, Tony Brake, Tisha Brewster, Jim Brulet, Jerry Connell, Lewis Cooper, Judith Dunham, Rick Elefant, Tom Felts, Julia Goldzmann, Greg Gothard, Dorothy Gregor, Jerry Hadfield, Aaron Haiman, Joshua Haiman, Mike Hall, Diane Jacobs, Eric Jepsen, Barbara Kelly, Sterling Kinnell, Carolyn Kolka, Ann Kositsky, Allison Levin, Charlene Lewis, Ed Lewis, Ina Lockwood, Fran McDermott, Yvonne McHugh, Fraser Meachem, Horacio Mena, Mona Mena, Paul Mirocha, Lisa Morse, Bob Numerof, Lisa Owens Viani, Ron Parker, Bill Prochnow, Jennie Rhine, Matt Ricketts, Anne Rock, Steve Rock, Kari Rodenkirchen, Jim Ross, Juta Savage, David Sexton, Robert Shepard, Karen Smith, Robert Smith, Polly Strahan, Jennifer Sullivan, Jan Sutcher, Cooper Walton, Martha Wilson, Step Wilson, Ken Windler, and Kathy Wolf.

We greatly appreciate the help of Amber Engle, Carlos de la Rosa, and the staff and volunteers of Lindsay Wildlife Experience for their help and cooperation collecting and sharing data on Trichomonas in San Francisco Bay Area bird populations. Leadership and advice for the study came from many individuals, including Buzz Hull, Mark Fenn, Reg Barrett, Aaron Haiman, Tony Brake, Karen Smith, Anton Muniz, Tina Cheng, Carla Cicero, Hans Peeters, Ryan McDougald, Jim DeRoque, and Bill Mannan. The GGRO is a long-term conservation-science program of the Golden Gate National Parks Conservancy in cooperation with the National Park Service. We are deeply appreciative of the generous support of the Gregory Hind Endowment, and of the hundreds of volunteers and donors who support the GGRO. This is GGRO scientific contribution number 155. Thank you to reviewers Robert Rosenfield, Kimball Garrett, and one anonymous reviewer for improvements to the manuscript.

\section{LITERATURE CITED}

Bates, D., Maechler, M., Bolker, B., and Walker, S. 2015. Fitting linear mixed-effects models using lme4. J. Stat. Software 67:1-48; doi.org/10.18637/jss.v067.i01.

Bird, D. M., Varland, D. E., and Negro, J. J. 1996. Raptors in Human Landscapes: Adaptations to Built and Cultivated Environments. Academic Press, London. 
Boal, C. W. 1997. The urban environment as an ecological trap for Cooper's Hawks. Ph. D. dissertation, Univ. Ariz., Tucson.

Boal, C. W. 2001. Nonrandom mating and productivity of adult and subadult Cooper's Hawks. Condor 103:381-385; doi.org/10.1093/condor/103.2.381.

Boal, C. W., and Mannan, R. W. 1998. Nest-site selection by Cooper's Hawks in an urban environment. J. Wildlife Mgmt. 62:864-871; doi.org/10.2307/3802537.

Boal, C. W., and Mannan, R. W. 1999. Comparative breeding ecology of Cooper's Hawks in urban and exurban areas of southeastern Arizona. J. Wildlife Mgmt. 63:77-84; doi.org/10.2307/3802488.

Boal, C. W., Mannan, R. W., and Hudelson, K. S. 1998. Trichomoniasis in Cooper's Hawks from Arizona. J. Wildlife Diseases 34:590-593; doi.org/10.7589/00903558-34.3.590.

Bosakowski, T., Speiser, R., Smith, D. G., and Niles, L. J. 1993. Loss of Cooper's Hawk nesting habitat to suburban development: Inadequate protection for a state-endangered species. J. Raptor Res. 27:26-30.

Chamberlain, D. E., Cannon, A. R., Toms, M., Leech, D., Hatchwell, B., and Gaston, K. 2009. Avian productivity in urban landscapes: A review and meta-analysis. Ibis 151:1-18; doi.org/10.1111/j.1474-919X.2008.00899.x.

Chiang, S. N., Bloom, P. H., Bartuszevige, A. M., and Thomas, S. E. 2012. Home range and habitat use of Cooper's Hawks in urban and natural areas. Studies Avian Biol. 45:1-16.

Estes, W. A., and Mannan, R. W. 2003. Feeding behavior of Cooper's Hawks at urban and rural nests in southeastern Arizona. Condor 105:107-116; doi.org/10.1093/ condor/105.1.107.

Mannan, R. W., and Boal, C. W. 2000. Home range characteristics of male Cooper's Hawks in an urban environment. Wilson Bull. 112:21-27; doi.org/10.1676/00435643(2000)112[0021:HRCOMC]2.0.CO;2.

Mannan, R. W., Steidl, R. J., and Boal, C. W. 2008. Identifying habitat sinks: A case study of Cooper's Hawks in an urban environment. Urban Ecosystems 11:141-148; doi.org/10.1007/s11252-008-0056-9.

Mayfield, H. 1961. Nesting success calculated from exposure. Wilson Bull. 73:255261.

Millsap, B. A. 2018. Demography and metapopulation dynamics of an urban Cooper's Hawk subpopulation. Condor 120:63-80; doi.org/10.1650/condor-17-124.1.

R Core Team. 2017. R: A language and environment for statistical computing. $\mathrm{R}$ Foundation for Statistical Computing, Vienna, Austria; https://R-project.org/.

Reynolds, R. T. 1983. Management of western coniferous forest habitat for nesting accipiter hawks. U.S. Forest Service Tech. Rep. RM-102; doi.org/10.2737/ RM-GTR-102.

Reynolds, R. T. 1989. Status reports: Accipiters, in Proceedings of the Western Raptor Management Symposium and Workshop (B. G. Pendleton, C. E. Ruibal, D. L. Krahe, K. Steenhof, M. N. Kochert, and M. L. LeFranc, eds.), pp. 92-101. Natl. Wildlife Fed., Washington, DC.

Rosenfield, R. N., Bielefeldt, J., Anderson, R. K., and Papp, J. M. 1991. Status reports: Accipiters, in Proceedings of the Midwest Raptor Management Symposium and Workshop (B. G. Pendleton, D. L. Krahe, M. N. LeFranc, Jr., K. Titus, J. C. Bednarz, D. E. Andersen, and B. A. Millsap, eds.), pp. 42-49. Natl. Wildlife Fed., Washington, DC.

Rosenfield, R. N., Bielefeldt, J., Affeldt, J. L., and Bechmann, D. J. 1995. Nesting density, nest area reoccupancy, and monitoring implications for Cooper's Hawks in Wisconsin. J. Raptor Res. 29:1-4.

Rosenfield, R. N., Hardin, M. G., Taylor, J., Sobolik, L. E., and Frater, P. N. 2019a. Nesting density and dispersal movements between urban and rural habitats 


\section{NESTING BIOLOGY OF URBAN COOPER'S HAWKS}

of Cooper's Hawks (Accipiter cooperii) in Wisconsin: Are these source or sink habitats? Am. Midland Nat. 182:36-51; 10.1674/0003-0031-182.1.36.

Rosenfield, R. N., Madden, K. K., Bielefeldt, J., and Curtis, O. E. 2019b. Cooper's Hawk (Accipiter cooperii), version 3.0, in The Birds of North America (P. G. Rodewald, ed.). Cornell Lab Ornithol., Ithaca, NY; doi.org/10.2173/bna. coohaw.03.

Rullman, S., and Marzluff, J. M. 2014. Raptor presence along an urban-wildland gradient: Influences of prey abundance and land cover. J. Raptor Res. 48:257-272; doi.org/10.3356/JRR-13-32.1.

Steenhof, K.,M., Kochert., N., McIntyre, C. I., and Brown, J. L. 2017. Coming to terms about describing Golden Eagle reproduction. J. Raptor Res. 51:378-390; doi.org/10.3356/JRR-16-46.1.

Stout, W. E., and Rosenfield, R. N. 2010. Colonization, growth, and density of a pioneer Cooper's Hawk population in a large metropolitan environment. J. Raptor Res. 44:255-267; doi.org/10.3356/JRR-09-26.1.

Stout, W. E., Rosenfield, R. N., Holton, W. G., and Bielefeldt, J. 2007. Nesting biology of urban Cooper's Hawks in Milwaukee, Wisconsin. J. Wildlife Mgmt. 71:366-375; doi.org/10.2193/2005-664.

Accepted 20 May 2020 


\section{NOTES}

\section{FIRST EVIDENCE OF BREEDING OF THE RED-NECKED GREBE IN CALIFORNIA}

KENNETH P. ABLE, Bob's Creek Ranch, 535-000 Little Valley Road, McArthur, California 96056; kennethpable@gmail.com

On 13 September 2019, I observed an adult Red-necked Grebe (Podiceps grisegena) accompanying two large young in juvenal plumage (Figure 1) near the boat-launch site on Big Lake, $\sim 6 \mathrm{~km}$ north of McArthur, Shasta County, California. Covering $\sim 3 \mathrm{~km}^{2}$, Big Lake is a relatively shallow ( $\sim 4 \mathrm{~m}$ deep) spring-fed lake at an elevation of $1008 \mathrm{~m}$. With other connected water bodies (Horr Pond, Tule, Little Tule, and Fall rivers), it is part of a large hydroelectric project constructed in the early decades of the $20^{\text {th }}$ century. The lake and several small islands are surrounded by a dense band of emergent aquatic vegetation, primarily tule (Schoenoplectus acutus). Pied-billed (Podilymbus podiceps), Eared (Podiceps nigricollis), Western (Aechmophorus occidentalis), and a few Clark's (A. clarkii) Grebes nest on the lake.

I observed the Red-necked Grebes from 14:20 to 15:20 PDT. The juveniles spent a majority of their time hidden in the shoreline tules. During this time, the adult patrolled in open water nearby. The juveniles emerged from the tules occasionally and consorted with the adult. When in the same field of observation with the adult, the juveniles appeared slightly smaller. Both juveniles dove numerous times during these forays in the open, but I did not see them catch anything. The adult was diving regularly during my observation, and it surfaced with prey on several occasions.



FIGURE 1. Adult (A) and one of two fledgling (B) Red-necked Grebes at Big Lake, near McArthur, Shasta County, California, 13 September 2019.

Photos by Kenneth P. Able 


\section{NOTES}

The adult did not feed the young birds while I was watching them, nor did they approach the adult and beg.

In the northwestern United States, the Red-necked Grebe breeds in northeastern Washington, northern Idaho, and northwestern Montana (AOU 1998, Dunn and Alderfer 2017). An isolated population at Rocky Point on Upper Klamath Lake, Klamath County, Oregon ( 165 km north-northwest of Big Lake), comprising from five to 20 birds, represented the only consistent breeding locality in that state known to Marshall et al. (2003). This population has declined, and there has been no documentation of nesting in recent years (Kevin Spencer pers. comm.). Occasional single adult Red-necked Grebes are reported in summer from inland Oregon and inland northern California, rarely in June and July, more frequently during August (www.eBird.org).

I do not know if the juvenile grebes were still flightless when I observed them. This raises the question whether the birds did not breed on Big Lake (or immediately connected bodies of water), but flew there from a distant nesting site. Given the Red-necked Grebe's breeding behavior, this seems unlikely. Young Red-necked Grebes begin to make exploratory dives by 2 weeks of age, are diving and feeding at about 4 weeks, but depend on parents for food for 6-8 weeks. They are able to fly by 7-9 weeks of age (De Smet 1983, Stout and Nuechterlein 1999). Departure from nesting lakes is staggered. One adult typically leaves 1-3 weeks prior to its mate, and both parents depart before their young, which disperse independently several days apart (De Smet 1983). An adult attending two juveniles indicates probable nesting locally, representing the first record of the Red-necked Grebe breeding in California.

Thanks to Kevin Spencer for providing current information on the grebes at Klamath Lake, Joseph R. Jehl for enlightenment about the parental behavior of grebes, and Jon L. Dunn, Kathy Molina, and Kimball Garrett for comments on the manuscript.

\section{LITERATURE CITED}

American Ornithologists' Union. 1998. Check-list of North American Birds, $7^{\text {th }}$ ed. Am. Ornithol. Union, Washington, D.C.

De Smet, K. D. 1983. Breeding ecology and productivity of Red-necked Grebes in Turtle Mountain Provincial Park, Manitoba. Master's thesis, Univ. of North Dakota, Grand Forks; https://commons.und.edu/theses/1162.

Dunn, J. L., and Alderfer, J. 2017. A Field Guide to the Birds of North America, $7^{\text {th }}$ ed. Natl. Geogr. Soc., Washington, D.C.

Marshall, D. B., Hunter, M. G., and Contreras, A. B. 2003. Birds of Oregon: A General Reference. Ore. State Univ., Corvallis.

Stout, B. E., and Nuechterlein, G.L. 1999. Red-necked Grebe (Podiceps grisegena), in The Birds of North America (A. F. Poole and F. B. Gill, eds.), no. 165. Acad. Nat. Sci., Philadelphia; doi.org/10.2173/bna/465. 


\title{
APPARENT USE OF A ROCK CREVICE AS A NOCTURNAL ROOST BY A RUBY-CROWNED KINGLET
}

\author{
EMILIE STRAUSS, P.O. Box 9426, Berkeley, California 94709; \\ desertpeach@earthlink.net \\ DAVID L. SWANSON, Department of Biology, University of South Dakota, \\ Vermillion, South Dakota 57069; david.swanson@usd.edu
}

Relatively little is known about the locations of North American landbirds' winter roosts (Skutch 1989, Dobbs and Martin 2000). North American Piciformes and cavity-nesting passerines have frequently been documented using cavities and variations thereof for overnight roosts during the non-nesting season, but relatively little is known about where passerines that nest in cups or other open structures spend the night (Skutch 1989, Dobbs and Martin 2000, Antczak 2010). The Rubycrowned Kinglet (Regulus calendula), an insectivorous cup-nesting species, has not been observed either nesting or roosting in cavities (Swanson et al. 2008). It breeds in coniferous forests in Canada, Alaska, northern New England, and the western United States, and winters across western, mid-central, and southern North America south through Mexico to Guatemala. In central California, the Ruby-crowned Kinglet winters commonly (Lepthien and Bock 1976, Swanson et al. 2008).

On 17 November 2017, along Deer Flat Road about $1 \mathrm{~km}$ northwest of Juniper Campground, Mount Diablo State Park, Contra Costa County, California, Strauss observed and filmed a Ruby-crowned Kinglet evidently examining a rock crevice for use as a nocturnal roost. This occurred during a period of prolonged subnormal temperatures and the day after a powerful two-day Pacific storm came through central California. On a cold and windy day, Strauss was hiking with a friend in Mount Diablo State Park just after sunset. She was surprised to observe a kinglet flutter along the $2-\mathrm{m}$ rock face and plunge into a small opening in the rock. As the rock crevice was at eye level, $1.4 \mathrm{~m}$ above the height of the fire road, she immediately recorded this behavior with an iPhone SE5. The video, available at https://flickr.com/photos/76353343@ N05/31763450227/in/datetaken-public/, shows 1.08 minutes of activity. In the cavity, the kinglet rotated back and forth on its belly as though hollowing out a depression, then ceased movement while simultaneously sealing the entrance with fluffed vent and belly feathers. The crevice, which measured $2.8 \mathrm{~cm} \times 3.6 \mathrm{~cm}$ at the mouth and narrowed slightly after the opening, almost completely concealed the bird. On a subsequent visit, Strauss inserted a metal tape into the crevice, measuring a depth of 8.6 $\mathrm{cm}$. Most of the crevice was too narrow to be used by the bird. Using packing peanuts loosely inserted into the crevice, Strauss determined that the volume of the crevice available to the kinglet was approximately $31.2 \mathrm{~cm}^{3}$. After 65 seconds, she inadvertently flushed the bird when she repositioned the phone closer to the rock cavity. The bird flew approximately $30 \mathrm{~m}$ along the escarpment, perching briefly several times on the rock bank, and then returned within $4 \mathrm{~m}$ of the crevice. Strauss hastily departed the area as she did not want to further hinder its efforts to find shelter. At 17:20, when the bird entered the crevice, it was almost dark. Sunset was at 16:57 and civil twilight at 17:25. Upon exiting, the kinglet partially exposed a red crown patch, identifying it as a male. Ruby-crowned Kinglets have not been documented using cavities as foraging habitat, and the bird did not appear to peck or otherwise behave as if foraging.

The elevation of Juniper Campground is $896 \mathrm{~m}$. During the 24 hours prior to this observation, the closest weather station (Mount Diablo summit, $1173 \mathrm{~m}$, Station SJS02) recorded temperatures from 2.2 to $7.3^{\circ} \mathrm{C}$ and wind speeds from 14 to $63 \mathrm{~km} /$ $\mathrm{hr}$ with gusts to $73 \mathrm{~km} / \mathrm{hr}$. Juniper Campground is located approximately $2 \mathrm{~km}$ west- 
southwest and $275 \mathrm{~m}$ below Mount Diablo's summit. At 17:20, the approximate time when the bird entered the crevice, the summit temperature was $3.6^{\circ} \mathrm{C}$ and the wind was from the north at $55 \mathrm{~km} / \mathrm{hr}$, thus producing a wind chill of $-3.5^{\circ} \mathrm{C}$. The cliff and crevice face southwest and were thus slightly protected from wind. Weather data are from https://www.mdia.org/mount-diablo-summit-weather.

Kendeigh (1972) stated that in birds and mammals the rate of metabolism per unit weight increases as body weight declines. At 5.0-9.7 g (male weight), the Rubycrowned Kinglet is not only one of North America's smallest songbirds but also one of the smallest birds to winter regularly north of $38^{\circ} \mathrm{N}$ latitude (Kendeigh 1972, Blem and Pagels 1984, Swanson et al. 2008). How does such a small species survive cold winter nights? Observations of roosting in the Ruby-crowned Kinglet are limited; on several occasions solitary birds perched in tree limbs close to the trunk (Swanson et al. 2008), and twice over a period of two weeks one individual entered a Verdin (Auriparus flaviceps) nest at twilight (Farley 1993). Although the Ruby-crowned Kinglet is considered a "winter durable" species, Laurenzi et al. (1982) found that its numbers declined precipitously during a very dry, cold winter in the lower Colorado River valley, suggesting the birds had either died or migrated.

None of the members of the Regulidae nest in cavities (Martens and Päckert 2006). Winter roosting strategies of two other species, the Golden-crowned Kinglet (Regulus satrapa) and Goldcrest (R. regulus), include huddling in communal groups (Reinertsen et al. 1988, Heinrich 2003) and occasional roosting in enclosed spaces. Examples of roosting in enclosed spaces are limited to a few observations of Goldencrowned Kinglets entering squirrel nests at dusk (Blem and Pagels 1984) and a single observation of three Goldcrests entering a snow hollow in Finland at sunset (Lagerstrøm 1979:171). The snow hollow "consisted of a recess in an earth bank, which was partly covered by overhanging grass and snow, and by the mantle of snow on the lower edge of the recess"; the hollow measured $20 \mathrm{~cm}$ in breadth and $10 \mathrm{~cm}$ in depth and was situated $1.5 \mathrm{~m}$ above the level of an adjacent road. Blem and Pagels (1984) calculated that the Golden-crowned Kinglet's lipid reserves are inadequate for it to survive cold winter nights, so they suggested it likely enters hypothermia. But later studies (Reinertsen et al. 1988) found that Goldcrests receiving adequate nutrition did not become hypothermic because of group huddling at night. Ruby-crowned Kinglets are not known to enter hypothermia or to huddle in groups at night during cold weather (Swanson et al. 2008, Farley 1993).

Another adaptation to cold in the Regulidae is the "fluffiness factor." Both the Golden-crowned and Ruby-crowned kinglets are relatively well insulated because their contour plumage is denser (representing $8.9-11.1 \%$ of body weight) than found in 73 other passerine species. Generally, contour plumage averages $7.5 \%$ of body weight (Wetmore 1936). In spite of its high insulative capacity, the Ruby-crowned Kinglet's capacity for metabolic heat production appears lower than predicted for a bird of its size. Its summit metabolic rate (i.e., maximum cold-induced metabolic rate) is lower than predicted for its body mass. In fall, the metabolic rates of females and males (Swanson 2007) are only $82 \%$ and $91 \%$, respectively, of the allometric predictions for birds (Swanson and Garland 2009). Therefore, because of its lower than predicted metabolic capacity, the Ruby-crowned Kinglet's tolerance for cold might be relatively poor, which might also make finding an appropriate microclimate for winter roosting a priority.

Choosing enclosed or protected winter nocturnal roost sites provides many benefits for small birds, and these advantages have been fairly well studied. Roosting in a rocky substrate provides protection from both predators and parasites (Velky et al. 2010, Doucette et al. 2011). Birds roosting in cavities or domed nests reduce their nocturnal energy consumption by up to $43 \%$ in comparison to birds roosting in exposed sites (Walsberg 1985). Cooper (1999) found that Juniper Titmice (Baeolophus ridgwayi) and Mountain Chickadees (Poecile gambeli) roosting in boxes during 
winter in Utah saved 25.1-37.6\% on their nocturnal energy expense because of the increased air temperature and shelter from the wind the box affords. Mayer et al. (1982) reported that Carolina Chickadees (P. carolinensis) roosting in cavities in winter reduced their radiant heat loss by $60-100 \%$ and their convective heat loss by $100 \%$.

What energy savings would a Ruby-crowned Kinglet accrue by roosting in a rock crevice? No data on the basal metabolic rate (BMR) or metabolic-rate increments below the lower critical temperature are available for the Ruby-crowned Kinglet (Swanson et al. 2008), but a rough estimate of energy savings can be predicted from allometric equations for birds. From McKechnie and Swanson (2010), the BMR for a bird of $6.5 \mathrm{~g}$ (the average mass of a male Ruby-crowned Kinglet from Dunning 2008) should be $0.40 \mathrm{ml} \mathrm{O}_{2}$ per minute. The lower critical temperature (LCT) defining the lower boundary of the thermal neutral zone (assuming a nocturnal body temperature of $39^{\circ} \mathrm{C}$ ) should be $22.7^{\circ} \mathrm{C}$ for a 6.5 -g bird (Weathers and van Riper 1982). On the basis of the allometrically predicted minimum thermal conductance below the LCT, oxygen consumption should increase by $0.029 \mathrm{ml} \mathrm{O}_{2}$ per minute per degree Celsius for a 6.5-g bird (Schleucher and Withers 2001). Given these values, the predicted metabolic rate of a bird resting at night at various ambient temperatures $\left(T_{\mathrm{a}}\right)$ can be calculated as BMR $+\left(\left[\mathrm{LCT}-T_{\mathrm{a}}\right] \times 0.029\right)$. By this method, the metabolic rate of a 6.5-g bird resting at night at $3.6^{\circ} \mathrm{C}$ (the temperature measured at the Mount Diablo summit weather station) should be $0.954 \mathrm{ml} \mathrm{O}_{2}$ per minute. With the wind-chill value of $-3.5^{\circ} \mathrm{C}$ calculated from the wind speed measured at Mount Diablo, the bird's predicted metabolic rate should be $1.160 \mathrm{ml} \mathrm{O}_{2}$ per minute. Provided that wind chill in the crevice is negligible, the metabolic rate should be equivalent to that at the ambient temperature of $3.6^{\circ} \mathrm{C}$, which is a $17.8 \%$ reduction in energy expenditure relative to roosting in the open with full exposure to the wind. If the bird warms the temperature within the cavity, which seems likely given the cavity's small volume and the kinglet's high rate of metabolic heat production, the energy savings should be even greater.

There are few studies of the microhabitats of wild birds that roost in vegetation and do not huddle (Dobbs and Martin 2000, Antzac 2010). Walsberg (1986) found that the Phainopepla (P. nitens) selects mistletoe clumps (Phoradendron californicum) to minimize thermal loss to the wind. Similarly, Buttemer (1985) reported that the American Goldfinch (Spinus tristis) chooses roost sites on the basis of wind protection. Dobbs and Martin (2000) observed that American Robins (Turdus migratorius) often roost in dense vegetation but away from the most thermally protected microhabitat, along the trunk, which likely enhanced their ability to detect predators (Walsberg and King 1980).

Several small rock-dwelling passerines, such as the Rock Wren (Salpinctes obsoletus), Canyon Wren (Catherpes mexicanus), and White-throated Swift (Aeronautes saxatalis), winter at northern latitudes (Jones and Dieni 1995, Lowther et al. 2000, Ryan and Collins 2000). Information on the nocturnal roosts of the two wrens is scarce. White-throated Swifts roost in rocks or concrete structures but sometimes enter torpor during cold weather (Ryan and Collins 2003).

One of the few well-documented studies of roosting in rocks addressed the Australian Owlet-nightjar (Aegotheles cristatus) (Doucette et al. 2011). Weighing about $50 \mathrm{~g}$, the nocturnal Australian Owlet-nightjar uses rocky crevices and tree cavities for diurnal roosts. Measurements of this species' roosts confirmed that rock crevices provide excellent thermal insulation and are consistently warmer than tree hollows. Like the White-throated Swift, this species enters torpor during extreme cold.

It is, of course, unclear if the Ruby-crowned Kinglet was intending to roost in the Mount Diablo cavity on the night of 17 November 2017. The behavior Strauss observed, however, was like that of the Great Tit (Parus major), which actively explores nest boxes at sunset prior to selecting one as a nocturnal roost (Velky et al. 2010).

Scientists have long been interested in how small songbirds survive cold winter nights. Increasing our knowledge of wintering avian thermal microhabitat associations and needs is a conservation priority and deserving of further study (Walsberg 


\section{NOTES}

1985, McClure et al. 2012). Rocks and cliffs may provide critical habitat even for arboreal birds and should be protected (Rumble 1987, Matheson and Larson 1998, Lambertucci and Ruggiero 2016).

Ingrid Crickmore waited patiently in cold during this observation. Birgit Marion translated a German article. Early drafts benefited from comments by Seth Bunnell and Rusty Scalf. Geoff Geupel provided exceptional editing on an earlier version of the manuscript. Matt Baumann, Daniel D. Gibson, and Philip Unitt provided support throughout preparation of this report.

\section{LITERATURE CITED}

Antczak, M. 2010. Winter nocturnal roost selection by a solitary passerine bird, the Great Grey Shrike Lanius excubitor. Ornis Fenn. 87:99-105.

Blem, C. R., and Pagels, J. F. 1984. Mid-winter lipid reserves of the Golden-crowned Kinglet. Condor 86:491-492; doi.org/10.2307/1366839.

Buttemer, W. A. 1985. Energy relations of winter roost-site utilization by American Goldfinches (Carduelis tristis). Oecologia 68:126-132; doi.org/10.1007/ BF00379484.

Cooper, S. J. 1999. The thermal and energetic significance of cavity roosting in Mountain Chickadees and Juniper Titmice. Condor 101:863-866; doi. org/10.2307/1370077.

Dobbs, R. C., and Martin, P. R. 2000. Winter nocturnal roost sites and behavior of some desert passerines in western Texas. W. Birds 31:120-122.

Doucette, L. I., Brigham, R. M., Pavey, C. R., and Geiser, F. 2011. Roost type influences torpor use by Australian Owlet-nightjars. Naturwissenschaften 98:845-854; doi.org/10.1007/s00114-011-0835-7.

Dunning, J. B., Jr. 2008. CRC Handbook of Avian Body Masses, $2^{\text {nd }}$ ed. CRC Press, Boca Raton, FL; doi.org/10.1201/9781420064452.

Farley, G. H. 1993. Observation of a Ruby-crowned Kinglet (Regulus calendula) roosting in a Verdin (Auriparus flaviceps) nest in winter. Southwest. Nat. 38:72-73; doi.org/10.2307/3671649.

Heinrich, B. 2003. Overnighting of Golden-crowned Kinglets during winter. Wilson Bull. 115:113-114; doi.org/10.1676/03-035.

Jones, S. L., and Dieni, J. S. 1995. Canyon Wren (Catherpes mexicanus), in The Birds of North America (A. Poole and F. Gill, eds.), no. 197. Acad. Nat. Sci., Philadelphia; doi.org/10.2173/bna.197

Kendeigh, S. C. 1972. Energy control of size limits in birds. Am. Nat. 106:79; doi. org/10.1086/282753.

Lagerstrøm, M. 1979. Goldcrests (Regulus regulus) roosting in the snow. Ornis Fenn. 56:170-171.

Lambertucci, S. A., and Ruggiero, A. 2016. Cliff outcrops used as condor communal roosts are local hotspots of occupancy and intense use by other bird species. Biol. Cons. 200:8-16; doi.org/10.1016/j.biocon.2016.05.013.

Laurenzi, A. W., Anderson, B. W., and Ohmart, R. D. 1982. Wintering biology of the Ruby-crowned Kinglet in the lower Colorado River valley. Condor 84:385-398; doi.org/10.2307/1367441.

Lepthien, L. W., and Bock, C. E. 1976. Winter abundance patterns of North American kinglets. Wilson Bull. 88:483-485.

Lowther, P. E., Kroodsma, D. E., and Farley, G. H. 2000. Rock Wren (Salpinctes obsoletus), in The Birds of North America (A. Poole and F. Gill, eds.), no. 486. Birds N. Am., Inc., Philadelphia; doi.org/10.2173/bna.486

Martens, J., and Päckert, M. 2006. Family Regulidae (kinglets \& firecrest), in Handbook of the Birds of the World (J. del Hoyo, E. Andrew, and D. A. Christie, eds.), vol. 11, pp. 330-349. Lynx Edicions, Barcelona. 
Matheson, J. D., and Larson, D. W. 1998. Influence of cliffs on bird community diversity. Can. J. Zool. 76:278-287; doi.org/10.1139/z97-195.

Mayer, L., Lustick, S., and Battersby, B. 1982. The importance of cavity roosting and hypothermia to the energy balance of the winter acclimatized Carolina Chickadee. Int. J. Biometeorol. 26:231-238; doi.org/10.1007/BF02184939.

McClure, J. W., Rolek, E. W., and Hill, G. E. 2012. Predicting occupancy of wintering migratory birds: Is microhabitat information necessary? Condor 114:482-490; doi.org/10.1525/cond.2012.110139.

McKechnie, A. E., and Swanson, D. L. 2010. Sources and significance of variation in basal, summit and maximal metabolic rates in birds. Current Zool. 56:741-758; doi.org/10.1093/czoolo/56.6.741.

Reinertsen, R. E., Haftorn, S., and Thaler, E. 1988. Is hypothermia necessary for the winter survival of the Goldcrest, Regulus regulus? J. Ornithol. 129:433-437; doi. org/10.1007/BF01644486.

Rumble, M. A. 1987. Avian use of scoria rock outcrops. Great Basin Nat. 47: 625-630.

Ryan, T. P., and Collins, C. T. 2000. White-throated Swift (Aeronautes saxatalis), in The Birds of North America (A. Poole and F. Gill, eds.), no. 526. Birds N. Am., Inc., Philadelphia; doi.org/10.2173/bna.526.

Ryan, T. P., and Collins, C. T. 2003. Activity patterns of White-throated Swifts in California. W. Birds 34:186-198.

Schleucher, E., and Withers, P. C. 2001. Re-evaluation of the allometry of wet thermal conductance for birds. Comp. Biochem. Physiol. A 129:821-827; doi. org/10.1016/S1095-6433(01)00356-7.

Skutch, A. F. 1989. Birds Asleep. Univ. of Texas Press, Austin.

Swanson, D. L. 2007. Cold hardiness and summit metabolism in North American kinglets during fall migration. Acta Zool. Sinica 53:600-606.

Swanson, D. L., and Garland, T., Jr. 2009. The evolution of high summit metabolism and cold tolerance in birds and its impact on present-day distributions. Evolution $63: 184-194 ; 10.1111 /$ j.1558-5646.2008.00522.x.

Swanson, D. L., Ingold, J. L., and Wallace, G. E. 2008. Ruby-crowned Kinglet (Regulus calendula), in The Birds of North America (A. Poole, ed.), no. 119, version 2.0. Cornell Lab. Ornithol., Ithaca, NY; doi.org/10.2173/bna.119.

Velky, M., Kanuch, P., and Kristin, A. 2010. Selection of winter roosts in the Great Tit Parus major: Influence of microclimate. J. Ornithol. 151:147-153; 10.1007/ s10336-009-0436-9.

Walsberg, G. E. 1985. Physiological consequences of microhabitat selection, in Habitat Selection in Birds (M. L. Cody, ed.), pp. 389-413. Academic Press, New York.

Walsberg, G. E. 1986. Thermal consequences of roost-site selection: The relative importance of three models of heat conservation. Auk 103:1-7; doi.org/10.1093/ auk/103.1.1.

Walsberg, G. E., and King, J. R. 1980. The thermoregulatory significance of winter roost-site selected by robins in eastern Washington. Wilson Bull. 92:33-39.

Weathers, W. W., and van Riper, C., III. 1982. Temperature regulation in two endangered Hawaiian honeycreepers: The Palila (Psittirostra bailleui) and the Laysan Finch (Psittirostra cantans). Auk 99:667-674.

Wetmore, A. 1936. The number of contour feathers in passeriform and related birds. Auk 53:159-169; doi.org/10.2307/4077274. 


\title{
UNUSUAL RECORD OF BONAPARTE'S GULL IN THE SIERRA SAN PEDRO MÁRTIR, BAJA CALIFORNIA
}

\author{
GORGONIO RUIZ-CAMPOS and GONZALO DE LEÓN-GIRÓN, Colección \\ Ornitológica, Facultad de Ciencias, Universidad Autónoma de Baja California, \\ Carretera Transpeninsular Ensenada-Tijuana No. 3917, Colonia Playitas, C.P. \\ 22860, Ensenada, Baja California, México; U.S. mailing address: PMB 064, P.O. Box \\ 189003, Coronado, California 92178; gruiz@uabc.edu.mx \\ HIRAM RAFAEL MORENO-HIGAREDA, Pro Esteros, A.C., Departamento de \\ Investigación, Calle Cuarta 210, Zona Centro, C. P. 22800, Ensenada, Baja California, \\ México
}

ARMANDO JESÚS CONTRERAS-BALDERAS, Cerro De La Conformidad 115, Las Puentes, Sector 2, C.P. 66460, San Nicolás de los Garza, Nuevo León, México

On 11 December 2015, during a snowstorm, De León-Girón found a Bonaparte's Gull (Chroicocephalus philadelphia) unable to fly and at the point of starvation near the ranger office of the Sierra de San Pedro Mártir National Park. The location is $30^{\circ}$ $59^{\prime} \mathrm{N}, 115^{\circ} 33^{\prime} 21^{\prime \prime} \mathrm{W}$, at an elevation of $2518 \mathrm{~m}$, and the vegetation is coniferous forest dominated by Pinus jeffreyi (Delgadillo-Rodríguez 2004). The bird died two days later. The specimen, an adult male, was prepared and deposited at the Universidad Autónoma de Baja California (UABC 2072; Figure 1). The pectoral mass of the dissected specimen confirmed the starved condition of this individual when it was found in the park during the snowstorm. Measurements include total length 360 $\mathrm{mm}$, wingspan $725 \mathrm{~mm}$, tarsus $35 \mathrm{~mm}$, wing length $237 \mathrm{~mm}$, tail $106 \mathrm{~mm}$, exposed culmen $29 \mathrm{~mm}$, and mass $115 \mathrm{~g}$, barely half the mean of $222 \mathrm{~g}$ reported for males by Burger and Gochfeld (2002).

In spite of numerous records of the species at and near sea level along both coasts of the Baja California peninsula, previous records from the interior of the peninsula are few, with none published before Wurster et al. (2001). None are from the Sierra San Pedro Mártir or as high as $2518 \mathrm{~m}$. Those in mountain habitats, from elevations $<1620 \mathrm{~m}$ at Laguna Hanson in the Sierra Juárez (one on 11 May 1997; four on 6 April 2000; Wurster et al. 2001) and Rancho Japá (14 May 2007, R. A. Erickson, via www.ebird.org), presumably represent spring migrants crossing from the Gulf of California to the Pacific coast. The date of our specimen suggests it was a fall migrant or winter visitor. Bonaparte's Gulls winter irregularly just north of the international border on the inland reservoirs of San Diego County (Unitt 2004), all at elevations below $920 \mathrm{~m}$ except for one report of one individual from Lake Cuyamaca (elevation $1412 \mathrm{~m}$ ), 10-18 December 2016 (photo by M. Colobianchi at https://ebird.org/ checklist/S32955657).

Ruiz-Campos and De León-Girón (2017) described a similar situation with the record of five Pacific Loons (Gavia pacifica) on this sky island at an elevation of 2428 $\mathrm{m}$, during a snowstorm on 15 November 2015. A month earlier than our Bonaparte's Gull, they presumably represented fall migrants crossing from the Pacific coast to the Gulf of California, retracing a path opposite the route by which the Pacific Loon departs the gulf in spring (Huey 1927). In this context, Grinnell (1928:55) had suggested the existence of a possible migratory route between the Pacific Ocean and the Gulf of California that crosses the mountain ranges of the northern Baja California peninsula. In both cases cited above, energetically spent individuals were downed by strong winds into unexpected habitats during the snowstorms.

We thank the park rangers of the San Pedro Mártir National Park for logistic support during our stay in the park, and M. E. Valles-Ríos for the preparation of the 


\section{NOTES}

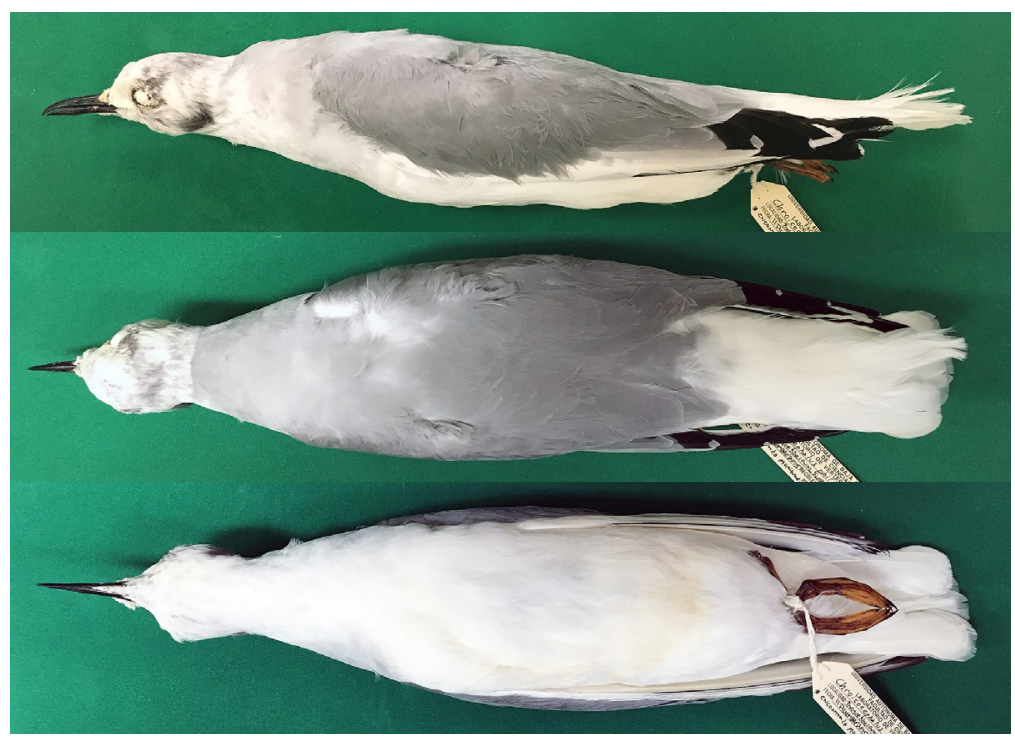

Figure 1. Male Bonaparte's Gull (UABC 2072) in lateral, dorsal and ventral view, collected 11 December 2015 at 2518 m in San Pedro Mártir National Park, Baja California.

\section{Photos by Gorgonio Ruiz-Campos}

specimen. Richard A. Erickson and Daniel D. Gibson made very useful comments that improved the clarity of the manuscript.

\section{LITERATURE CITED}

Burger, J., and Gochfeld, M. 2002. Bonaparte's Gull (Larus philadelphia), in The Birds of North America (A. Poole and F. Gill, eds.), no. 634. Birds N. Am., Inc., Philadelphia; doi.org/10.2173/bow.bongul.01.

Delgadillo-Rodríguez, J. 2004. El bosque de coníferas de la Sierra de San Pedro Mártir, Baja California, México. Secretaría de Medio Ambiente y Recursos Naturales-Instituto Nacional de Ecología, México, D.F.

Grinnell, J. 1928. A distributional summation of the ornithology of Lower California. Univ. Calif. Publ. Zool. 32:1-300.

Huey, L. M. 1927. Observations on the spring migration of Aphriza and Gavia in the Gulf of California. Auk 44:529-531; doi.org/10.2307/4074844.

Ruiz-Campos, G., and De León-Girón, G. D. 2017. Registro del colimbo pacífico ( $\mathrm{Ga}$ via pacifica) en el Parque Nacional Sierra de San Pedro Mártir, Baja California, México. Huitzil 18(1):11-15; doi.org/10.28947/hrmo.2017.18.1.257.

Unitt, P. 2004. San Diego County bird atlas. Proc. San Diego Soc. Nat. Hist. 39.

Wurster, T. E., Erickson, R. A., Hamilton, R. A., and Howell, S. N. G. 2001. Database of selected observations: An augment to new information on migrant birds in northern and central portions of the Baja California Peninsula, in Birds of the Baja California Peninsula: Status, Distribution, and Taxonomy (R. A. Erickson and S. N. G. Howell, eds.), pp. 204-237. Am. Birding Assoc. Monogr. Field Ornithol. 3. 


\section{BOOK REVIEWS}

The Home Place: Memoirs of a Colored Man's Love Affair with Nature, by J. Drew Lanham. 2017. Milkweed Editions, 240 pp. ISBN: 978-1-57131-350-8.

As I read The Home Place I felt honored to hear the story of another black birder. Statements like "Nature was often the first and last thing on my mind, morning to night" and "I felt closer to flight by bringing the birds closer to my earthbound existence" could have been peeled directly out of my mind. But on another level, the statement "Responses in forest and field are not born of any preconceived notions of what 'should be.' They lie only in the fact that I am." went straight to my heart.

Physically, I liked that the book was in hard cover, well constructed. The $81 / 4^{\prime \prime}$ $\times 53 / 4$ " was a nice size, and the 240 pages alluded to the book's being a fairly quick read. The vanilla pages were perfect. The cover jacket showed pictures that felt familiar, family pics: taken possibly by a non-photographer relative, old black and whites, portraits with the top of the head cut off, old Polaroids. Very similar to my own family portraits.

But there is a picture of what appears to be a Carolina Wren down in the lower left corner as kind of a tip-off that there is probably more to this book than the typical family memoir. Dr. Lanham started out giving reasons as to how and why he got into nature writing, beyond his role as distinguished professor of wildlife ecology at Clemson University. One of my favorites is "Heart and mind cannot be exclusive of one another in the fight to save anything."

The reading was easy. And as I read, I loved the way Lanham interwove nature, birds and plants, into almost every situation. He gave a very rich and diagnostic description of the physical region of South Carolina that he calls home. Just the thing a good naturalist would do. Lanham described with vivid detail many of the things that made him who he is. His vignettes of the members of his family are intriguing, and his love for his "Mamatha" is palpable. As Lanham describes his personal development he moves through a number of places and periods, ups and downs, lefts and rights, that are amazing in and of themselves. Nevertheless, there is a base theme of nature and rich black dirt throughout that glues the whole story together nicely.

But Lanham's story wasn't all biscuits and molasses. Getting out into nature is no mean feat for anyone, there are any number of things one must consider. But when you add on the racial history of this country it can become a gauntlet.

"Courage faces fear and thereby masters it. Cowardice represses fear and is thereby mastered by it. Courageous men never lose the zest for living even though their life situation is zestless; cowardly men, overwhelmed by the uncertainties of life, lose the will to live. We must constantly build dikes of courage to hold back the flood of fear."-Martin Luther King

To me this is the only way our country is going to move forward. The number of people of color who dare to love nature full-time, is thin at best, with good reason. For a long time I perceived I was alone in my pursuit and appreciation of nature. This book is the encouragement I wish I had in my early years. A person of color writing a very good book like this is a big deal for me. I applaud you Joseph Drew Lanham, as a wordsmith, ornithologist, and African-American who followed his path with courage. 
American Birds: A Literary Companion, edited by Andrew Rubenfeld and Terry Tempest Williams. 2020. Library of America, distributed by Penguin Random House. 285 pp., encompassing 83 selected poems, journal entries, memoirs, short stories, essays, and travel accounts by 75 writers. ISBN: 978-1-59853-655-3.

The joy of watching birds in their natural environs has never found sole expression in moments of quiet, self-contained exhilaration. For all its characterization as a mash-up of solitary intellectual activity and a sport of personal bests, birding as a pastime has never been exclusionary or arcane. Who among us-serious birder or casual observer-hasn't turned a memorable moment in the field into a relatable tale of discovery and exuberance? Some have gone even further, communicating their ecstasy with the aid of the paintbrush, the camera, or the pen.

It is the last instrument that has been wielded to exquisite effect in a new book edited by Andrew Rubenfeld and Terry Tempest Williams, aptly titled American Birds: A Literary Companion. Comprising works from an impressive medley of sources, this volume captures the vibrancy of New World avifauna as it has inspired, affected, and awed wordsmiths of every stripe over the span of more than two centuries.

Personal observation and firsthand accounts provide the impetus for this compilation. The prefatory "Three American Indian Songs About Birds" embark the reader on a literary odyssey that continues with a sampling of essays, monographs, poems, journal entries, and book excerpts. All share an overarching theme: the celebration of Nearctic birds; that is, those birds whose place of habitation is (or once was) the North American continent.

The results of this endeavor are distinctive, vivid, and inspiring. Meriwether Lewis, writing in his journal about the woodpecker that would later bear his name, transports us to an age when the continent west of the of the Mississippi was just becoming known to the outside world, when a crisply written description of a bird could both educate and aspire to the loftiest of sight records: that which was new to science. Barry Lopez, embracing a more conversational tone in his essay "The Raven," not only describes that species to a fault, but deftly differentiates it from its corvid cousin, the American Crow.

It's not just the birds themselves, but their strong connection to iconic places in the American landscape that especially resonated with me. I warmed all over again to a chapter from Mary Winn's "Red-tails in Love," her adoring chronicle of a pair of hawks that attained near-celebrity status when they took to nesting on a high-rise facing Manhattan's Central Park. Equally stirring was Pamela Uschuk's 2006 poem "Snow Goose Migration at Tule Lake," in which she limns an image of "the iris-eyed dawn and the slow blind buffalo of fog," followed by "the thermonuclear flash of snow geese, huge white confetti ... across Shasta's silk peak.” Anyone who has visited Tule Lake in winter knows exactly what she means.

These are but a minuscule sampling of the rich cross section of material contained in this anthology. Men and women of letters predominate, but there are personages from other walks of life, too. Some, like John James Audubon, Theodore Roosevelt, Roger Tory Peterson, or Rachel Carson need no introduction; others, such as Sarah Orne Jewett and Florence A. Merriam - two early champions of bird conservationare less renowned. All are handsomely represented in this text.

Delightful surprises abound. Who knew that Carl Sandburg devoted a poem to the subject of the Purple Martin? Or that Emily Dickinson's prodigious output included an ode to the Bobolink? We also learn that long before "moon-watching" became a trend among today's birders, Walt Whitman listened with relish to the nocturnal calls of migrants overhead, and that the late novelist Ursula Le Guin took respite from her science fiction writing to wax poetically about a Cactus Wren, whose "small quicksilver trill... has no messages for men." 
There are some regrettable omissions, to be sure. I missed the inclusion of anything by Scott Weidensaul, one of today's most prolific and talented writers on the subjects of birds and birding. The redoubtable Arthur Cleveland Bent receives only brief mention-a snippet from his life histories as cited by another author. The book is also bereft of the oft overlooked publications of Ralph Hoffman. I still cling to my tattered, out-of-print 1927 edition of Hoffman's Birds of the Pacific States for its singularly precise and colorful species accounts. Perhaps there were obstacles to securing copyrights to one or more of the above. Or maybe the amount of suitable material mined for this project was so daunting, it was simply impossible to give every worthy entry its due.

Elisions aside, the editors have chosen well. Their painstaking efforts have served up a gathering of literary excellence stunning in its variety and appeal. Ms. Williams, herself a writer of considerable accomplishment, didn't allow modesty to keep her from adding a sample from her own wonderful oeuvre. On the face of it, her essay "The Peregrine" is a paean to the falcon that lends its name to the title. Read further into this opus, though, and she turns the occasion of watching flocks of reviled European Starlings from the vantage of the Salt Lake City dump into a moment of rapture. Only an artist of her special gifts could pull this off.

The timeliness of this anthology, three years in the making, is almost preternatural. Rubenford and Williams have demonstrated that the enthusiasm for birdwatching in this country is one that transcends race, ethnicity, and class. Witness that in this single volume, one can read the portraiture of a dipper by Scottish-born naturalist John Muir, a rumination on crows by African-American poet Cornelius Eady, and an observational riff on hummingbirds ("arcing their bodies in grim determination to find what is good") by Chicana poet Lorna Dee Cervantes. True to the spirit of its title, American Birds: A Literary Companion affirms not only the diversity of bird life in this great land, but that of the people who capture its essence in words.

I can think of no better antidote to these discordant times. "Everyone is a birdwatcher, but there are two kinds of birdwatchers: those who know what they are and those who haven't yet realized it," writes Jonathan Rosen, who realized it from a very young age while growing up in New York. This sumptuous collection is testimony to his words, and a most treasured addition to one's library.

David Koeppel 


\section{FEATURED PHOTO}

\section{SANDERLING SCAVENGING CRAB FRAGMENTS FROM A FORAGING WESTERN GULL}

FLOYD E. HAYES, Department of Biology, Pacific Union College, 1 Angwin Ave., Angwin, California 94508; floyd_hayes@yahoo.com

VIVEK KHANZODE, 1623 Mariani Dr., Sunnyvale, California 94087;

birdpixel@gmail.com

The Sanderling (Calidris alba) normally forages on a variety of live prey (Macwhirter et al. 2002). There are only a few previous reports of Sanderlings scavenging dead prey, including the carcasses of dead jellyfish and fishes on beaches (Gochfeld and Burger 1980, King 1981, Grimm 1984, Reneerkens et al. 2009). In two of these reports the Sanderlings scavenged fish carcasses after they had been ripped open by scavenging Herring Gulls (Larus argentatus; Gochfeld and Burger 1980) or Lesser Black-backed Gulls (L. fuscus; King 1981). In this note we document a Sanderling scavenging a crab preyed upon by a foraging Western Gull (L. occidentalis).

On the evening of 3 April 2011, Khanzode visited Half Moon Bay, San Mateo County, California, to photograph migrating shorebirds. At 17:51, he observed a Western Gull capture and kill a Northern Kelp Crab (Pugettia producta) on Maverick's Beach at Pillar Point $\left(37^{\circ} 29^{\prime} 47^{\prime \prime} \mathrm{N}, 122^{\circ} 29^{\prime} 44^{\prime \prime} \mathrm{W}\right)$. As the gull manipulated the crab, a Sanderling flew in, stood within $0.5 \mathrm{~m}$ behind or to the side of the gull, and watched the gull devour the crab (see this issue's back cover, top photo). The Sanderling did not attempt to snatch the crab from the gull, and the gull ignored the Sanderling. After spending several minutes consuming a few large morsels of the crab, the gull abandoned the crab's carcass and flew away just after 18:00. Immediately afterward, at 18:01, the Sanderling began picking off the smaller pieces of crab tissue that the gull had left behind in the crab's carapace (back cover, middle and bottom photos). The Sanderling continued feeding on the crab carcass for about 15 min until all of the tissue was consumed.

This appears to be the first documented instance of a Sanderling scavenging on prey directly from a predator. Scavenging dead prey from a predator or another scavenger may be passive (beneficial for the perpetrator, neutral for the host) or result from kleptoparasitism, in which dead food is stolen from a host (beneficial for the perpetrator, costly for the host; Brockmann and Barnard 1979, Focardi et al. 2017). Herbert et al. (2019) pointed out that there is a continuum from passively scavenging dropped prey to aggressively coercing a victim to relinquish food. They suggested that the behavior switches from scavenging to kleptoparasitism when a victim takes evasive maneuvers to defend its food. In this case the Western Gull never took evasive measures to avoid losing its food to the Sanderling, which did not attempt to feed on the crab until after the gull departed, so this observation represents an instance of passive scavenging without any benefit or cost to the gull. Although the behavior is rarely reported in the literature, Sanderlings may scavenge prey fragments from predators or other scavengers more frequently than is currently recognized.

\section{LITERATURE CITED}

Brockmann, H. J., and Barnard, C. J. 1979. Kleptoparasitism in birds. Anim. Behav. 27:487-514; doi.org/10.1016/0003-3472(79)90185-4.

Focardi, S., Materassi, M., Innocenti, G., and Berzi, D. 2017. Kleptoparasitism and scavenging can stabilize ecosystem dynamics. Am. Nat. 190:398-409; doi. org/10.1086/692798. 
Grimm, P. 1984. Gonaden der Ohrenqualle (Aurelia aurita) als Nahrung des Sanderlings (Calidris alba). Seevögel 5:24.

Gochfeld, M., and Burger, J. 1980. Opportunistic scavenging by shorebirds: Feeding behavior and aggression. J. Field Ornithol. 51:373-375.

Herbert, S. S., Hayes, F. E., and Hellie, M. H. 2019. Kleptoparasitism of the Sea Otter (Enhydra lutris) and Steller Sea Lion (Eumetopias jubatus) by the Glaucouswinged Gull (Larus glaucescens) at Seward, Alaska. Polar Biol. 42:1935-1941; doi.org/10.1007/s00300-019-02559-4.

King, B. 1981. Feeding behaviour of wintering Sanderlings. Br. Birds 74:521-522.

Macwhirter, R. B., Austin-Smith, P. Jr., and Kroodsma, D. E. 2002. Sanderling (Calidris alba), in The Birds of North America (A. F. Poole and F. B. Gill, eds.), no. 653. Birds N. Am., Inc., Philadelphia; doi.org/10.2173/bna.653.

Reneerkens, J., Benhoussa, A., Boland, H., Collier, M., Grond, K., Günther, K., Hallgrimsson, T. G., Hansen, J., Meissner, W., De Meulenaer, B., Ntiamoa-Baidu, Y., Piersma, T., Poot, M., Van Roomen, M., Summers, R. W., Tomkovich, P. S., and Underhill, L. G. 2009. Sanderlings using African-Eurasian flyways: A review of current knowledge. Wader Study Group Bull. 116:1-20.

Accepted 9 September 2020

\section{THANKS TO WESTERN BIRDS' REVIEWERS AND ASSOCIATE EDITORS}

Peer review is a critical step in the publication of a scientific journal. I thank the following people for their generosity in taking the time to provide this essential service sustaining the scientific quality of Western Birds for volume 51: Kenneth P. Able, Daniel A. Airola, Daniel W. Anderson, George Barrowclough, Samuel Bressler, G. Vernon Byrd, Phillip J. Capitolo, Matthew D. Carling, Emily W. Clark, Robert H. Doster, Jon L. Dunn, Richard A. Erickson. Ted Floyd, Kimball L. Garrett, Daniel D. Gibson, Scott Gillihan, R. J. Gutiérrez, Anders Gyllenhaal, Lori Hargrove, Richard W. Hedley, Steven C. Heinl, Watcharapong Hongjamrassilp, Steve N. G. Howell, Rich C. Hoyer, Jon Isacoff, Harry R. Jageman, Joseph R. Jehl, Jr., Deven Kammerichs-Berke, Paul E. Lehman, Tony Leukering, James M. Maley, Joel Martin, Steven M. Matsuoka, Ryan Merrill, Kathy C. Molina, John Neill, Ryan P. O’Donnell, Robert L. Pitman, Ron Pittaway, Peter Pyle, Mark J. Rauzon, Terrell D. Rich, Bryce Robinson, Robert N. Rosenfield, Daniel R. Ruthrauff, Daizaburo Shizuka, Allison Shultz, Bridget J. Stutchbury, David L. Swanson, Charles Swift, Ryan Terrill, Scott B. Terrill, Tad C. Theimer, Heather Watts, David White, and Jack J. Withrow.

Thank you to our associate editors Kenneth P. Able, Matthew J. Baumann, Daniel S. Cooper, Douglas W. Faulkner, Kimball L. Garrett, Daniel D. Gibson, Robert E. Gill, Daniel R. Ruthrauff, and Christopher W. Swarth for their service in coordinating reviews and serving as reviewers themselves. Thank you to John Sterling for his nine years of outstanding service as featured photo editor, and to Ryan Terrill for stepping up to fill that role. And thank you to assistant editor Dan Gibson, graphics manager Ginger Johnson, photo editor Peter LaTourrette, and webmaster/designer/ typographer Tim Brittain for continuing as an essential part of our editorial team through 2020. 


\title{
WESTERN BIRDS, INDEX, VOLUME 51, 2020
}

\author{
Compiled by Daniel D. Gibson
}

Able, Kenneth P., First Evidence of Breeding of the Red-necked Grebe in California, 318-319

Acanthis flammea, 249

Accipiter cooperii, 307-317

Águila, Sergio, see Carmona, R.

Alauda arvensis, 228, 248

Albatross, Short-tailed, 11

Amazilia violiceps, 231

Ammodramus savannarum, 36

Ammospiza leconteii, 21, 249-251

Anas acuta, 82

crecca, 28, 82

querquedula, 4

Anderson, Clayton, Book Review: The Home Place: Memoirs of a Colored Man's Love Affair with Nature, 327

Ani, Groove-billed, 4

Anser canagicus, 4

Anthus gustavi, 20-21

Antigone canadensis, 82

Antrostomus ridgwayi, 230

Archilochus colubris, 4, 230

arcticola, Calidris alpina, 83

Ardea alba, 190-220

herodias, 190-220

Ardenna gravis, 14

pacifica, 14, 237

barrovianus, Larus hyperboreus, 86

Bartramia longicauda, 83, 231

Benson, Thomas A., Fowler, Rob, McCaskie, Guy, and Stahl, Justyn T., The 44th Annual Report of the California Bird Records Committee: 2018 Records, 228-260; see Singer, D. S.

bewickii, Cygnus columbianus, 78, 81-82

Blackbird, Brewer's, 22

Rusty, 22, 229, 252

Black Hawk, Common, 22, 242, 255

Bluebird, Mountain, 47-58

Bluetail, Red-flanked, 228, 248-249

Bobwhite, Northern, 65

Bombycilla cedrorum, 92-103 garrulus, 92-103

Booby, Masked, 14, 129-149, 238-239

Masked/Nazca, 14-15, 131, 229, 240

Nazca, 14, 129-149, 229, 239-240

Red-footed, 15, 229, 240-241

Bosma, Mitchel D., Ross, Hayley H., and Douglas, Robert B., Northern Pygmy-
Owl Predation on an Adult California Quail, 65-67

Brant, 29

Branta bernicla, 29 hutchinsii, 81

Briggs, Christopher W., see Pericoli, R. V. Brotogeris chiriri, 228, 254

brunnescens, Callipepla californica, 66

Bubulcus ibis, 190-220

Bulbul, Red-whiskered, 228, 254-255

Bulweria bulwerii/fallax, 235-237 fallax, 235

Bunting, McKay's, 78-80, 88, 174-189

Snow, 21, 88, 174-189, 249

Varied, 254

Buteo plagiatus, 228, 242-245

Buteogallus anthracinus, 22, 242, 255

Calcarius pictus, 33-36

Calidris alba, 330-331

alpina, 62, 82, 83

canutus, 83

ferruginea, 231

fuscicollis, 233

mauri, 82, 83

minuta, 10, 233

ptilocnemis, 78-91

pugnax, 29

ruficollis, 8

subruficollis

californica, Sula dactylatra, 129

Callipepla californica, 65-67

gambelii, 65

Calonectris diomedea, 237

canadensis, Antigone canadensis, 82

Caracara, Crested, 32

Caracara cheriway, 32

Cardellina rubrifrons, 255

Carmona, Roberto, Marrón, Gerardo, Águila, Sergio, Rivas, Abigail, Flores Ramírez, Sergio, and Reyes Bonilla, Héctor, Population Assessment of Belding's Yellowthroat (Geothlypis beldingi) at San Ignacio Oasis, Baja California Sur, Mexico, 38-46

carolinensis, Anas crecca, 82

Cathartes aura, 15

Catharus fuscescens, 249 minimus, 20

caurina, Strix occidentalis, 66

celsum, Toxostoma curvirostre, 249 


\section{INDEX}

chapmani, Hydrobates leucorhous, 237

Charadrius hiaticula, 82-83, 228, 231 semipalmatus, 83, 231

Chat, Yellow-breasted, 167-171

Yellow-breasted $\times$ oriole, $167-171$

Chickadee, Black-capped, 267

Mountain, 267

chicken, domestic, 65 domestic $\times$ Helmeted Guineafowl, 151-153

chiriri, Brotogeris chiriri, 254

Chlidonias niger, 192, 194, 211

Chroicocephalus philadelphia, 325-326 ridibundus, 11, 234

Circus hudsonius, 117

Cistothorus platensis, 19

Clark, Kevin B., see Unitt, P.

Colinus virginianus, 65

columbianus, Cygnus columbianus, 78, 81-82

Columbina passerina, 29 talpacoti, 230

Condeso, T. Emiko, see Shuford, W. D.

Condor, Andean, 15

Contopus pertinax, 19, 245 virens, 19

Contreras-Balderas, Armando Jesús, see Ruiz-Campos, G.

Cooper, Daniel S., see Shuford, W. D.

Coot, American, 156

American $\times$ Common Gallinule, 150-156

Eurasian $\times$ Eurasian [= Common] Moorhen, 150

Coragyps atratus, 15, 242

Cormorant, Double-crested, 214, 215, 270-292

Pelagic, 78-91

Corvus corax, 86

coturniculus, Laterallus jamaicensis, 111-121

Crane, Sandhill, 82

Creagrus furcatus, 3, 10-11

crecca, Anas crecca, 28, 82

Crossbill, Red, 21

White-winged, 3, 21, 255

Crotophaga sulcirostris, 4

curvirostre, Toxostoma curvirostre, 249

Cyanocitta cristata, 23, 266 cristata $\times$ C. stelleri, 266

Cygnus buccinator, 29, 230 columbianus, 78, 81-82, 230

Cynanthus latirostris, 4-5, 230-231

DeGange, Anthony R., see Robinson, B. W. de Groot, Leo, see Pearman, M.

de León-Girón, Gonzalo, see Ruiz-Campos, G.

Dendrocygna autumnalis, 4 bicolor, 229-230

diazi, Anas platyrhynchos, 28

Dickcissel, 36

domesticus, Gallus gallus, 65

Douglas, Robert B., see Bosma, M. D.

Dove, Common Ground-, 29

Ruddy Ground, 230

Duck, Black-bellied Whistling-, 4

Fulvous Whistling-, 229-230

Dunlin, 62, 82, 83

Eagle, Bald, 86

Eckert, Cameron D., and Gordon, Richard R., Hirundo rustica rustica at Herschel Island-Qikiqtaruk, Yukon-a Barn Swallow Subspecies New to Canada, 104-110

Egret, Cattle, 190-220

Great, 190-220

Reddish, 32

Snowy, $190-220$

Egretta caerulea, 204

rufescens, 32

thula, 190-220

tricolor, 15, 241-242

Eider, King, 4, 230

emeria, Pycnonotus jocosus, 255

Empidonax alnorum, 245-248

difficilis/occidentalis, 19, 245

flaviventris, 19, 245, 255

minimus, 32

traillii, 248

Erickson, Richard A., and Rottenborn, Stephen C., Two Photographed American Coot $\times$ Common Gallinule Hybrids, 150-156

erythrogaster, Hirundo rustica, 104-110

Euphagus carolinus, 22, 229, 252 cyanocephalus, 22

Evens, Jules, Temporal Response of California Black Rails to Tidal Wetland Restoration, 111-121

Falco rusticolus, 245 tinnunculus, 18

Ficedula hypoleuca, 62

Finch, Gray-crowned Rosy-, 78, 87-88 Purple, 33

Fish, Allen M., see Pericoli, Ralph V.

Flores Ramírez, Sergio, see Carmona, R. Flycatcher, Alder, 245-248

Ash-throated, 18, 167 


\section{INDEX}

Dusky-capped, 3, 18, 32

Fork-tailed, 18

Great Crested, 18

Least, 32

Pacific-slope/Cordilleran, 19, 245

Pied, 62

Scissor-tailed, 32

Streaked, 245

Sulphur-bellied, 245

Willow, 248

Yellow-bellied, 19, 245, 255

Fowler, Rob, see Benson, T. A.

Fregata magnificens, 45 magnificens/minor/ariel, 23

Frigatebird, Magnificent, 45 Magnificent/Great/Lesser, 23

Fulica americana, 156 americana $\times$ Gallinula galeata, 150-156 atra, 155 atra $\times$ Gallinula chloropus, 150

gallinago, Gallinago gallinago, 83

Gallinago delicata, 83 gallinago, 83

Gallinula chloropus, 155

chloropus $\times$ Fulica atra, 150

galeata, 156

galeata $\times$ Fulica americana, 150-156

Gallinule, Common $\times$ American Coot, 150-156

Florida [= Common], 155

Purple, 231

Gallus gallus, 65 gallus $\times$ Numida meleagris, 151-153

Gannet, Northern, 22, 143, 255

Garganey, 4

Gavia adamsii, 11, 30, 235

arctica, 11, 86, 235

pacifica, 86

Geothlypis beldingi, 38-46

formosa, 3,36

philadelphia, 22, 253, 255

Gill, Robert E. Jr., see Robinson, B. W.

Giusti, Kevin A., see Walker-Roseman, L. D.

Glaucidium gnoma, 65-67

Godwit, Bar-tailed, 5-6, 231

Hudsonian, 231

Golden-Plover, European, 3, 62, 231

Pacific, 82

Goldfinch, Lawrence's, 33

Goose, Cackling, 81 Emperor, 4

Gordon, Richard R., see Eckert, C. D.

Grackle, Common, 252
Grebe, Eared, 194

Red-necked, 318-319

Greenshank, Common, 83-84

griseonucha, Leucosticte tephrocotis, 87

Grosbeak, Blue, 167

Grosselet, Manuel, see Pieplow, N.

Ground-Dove, Common, 29

Ground Dove, Ruddy, 230

Grube, Matthew, A Possible First Hybrid of Icteria $\times$ Icterus, $167-171$

Guineafowl, Helmeted $\times$ domestic chicken, 151-153

Gull, Black-headed, 11, 234

Black-tailed, 11, 234

Bonaparte's, 325-326

California, 211, 234

Glaucous, 85-86

Glaucous-winged, 78, 85-86

Herring, 78, 85-86, 234

Laughing, 30

Ring-billed, 211

Ross's, 3, 11, 85

Slaty-backed, 11, 234

Swallow-tailed, 3, 10-11

Western, 330-331

Yellow-legged, 234

gutturalis, Hirundo rustica, 104-110

Gyrfalcon, 245

Haemorhous purpureus, 33

Haliaeetus leucocephalus, 86

haliaetus, Pandion haliaetus, 86

Hampton, Steve, The 2018 Flight of the Buff-breasted Sandpiper, 72-74

Hargrove, Lori, see Unitt, P.

Harrier, Northern, 117

Hawk, Common Black, 22, 242, 255

Cooper's, 307-317

Gray, 228, 242-245

Harris's, 32

Hayes, Floyd E., and Khanzode, Vivek, Sanderling Scavenging Crab Fragments from a Foraging Western Gull, 330-331; see also Walker-Roseman, L. D.

Helmitheros vermivorum, 22, 252

Heron, Black-crowned Night-, 190-220

Great Blue, 190-220

Little Blue, 204

Tricolored, 15, 241-242

Yellow-crowned Night-, 204

Hirundo rustica, 104-110

Holroyd, Geoffrey L., see Pearman, M.

Hummingbird, Broad-billed, 4-5, 230-231

Ruby-throated, 4, 230 


\section{INDEX}

Violet-crowned, 231

Hydrobates castro, 3, 11-13

leucorhous, 237

melania, 235

microsoma, 235

socorroensis, 13

tethys, 13, 235

tristrami, 228

Hydroprogne caspia, 211

Hylocichla mustelina, 20, 255

Ibis, Glossy, 15, 242

White-faced, 156, 242

Icteria virens, $167-171$

virens $\times$ Icterus, $167-171$

Icterus bullockii, 167, 169

cucullatus, 167, 169

galbula, 167

parisorum, 167

pustulatus, 255

spurius, 21, 36, 167

Ictinia mississippiensis, 16, 32, 242

insulae, Plectrophenax nivalis, 186

Jaeger, Parasitic, 85

Jay, Blue, 23, 266

Blue $\times$ Steller's Jay, 266

jocosus, Pycnonotus jocosus, 255

Johnson, Andrew S., see Robinson, B. W.

Johnson, James A., see Robinson, B. W.

Jongsomjit, Dennis, see Shuford, W. D.

Jynx torquilla, 3, 16-18

kamtschaticus, Corvus corax, 86

Karsten, Emma L., see Pericoli, R. V.

Kelly, John P., see Shuford, W. D.

Kestrel, Eurasian, 18

Khanzode, Vivek, see Hayes, F. E.

Kingbird, Couch's, 32

Thick-billed, 18, 32, 245

Tropical, 32

Kinglet, Ruby-crowned, 320-324

Kite, Mississippi, 16, 32, 242

Kittiwake, Red-legged, 78, 80-81, 85

Knot, Red, 83

Koeppel, David, Book Review: American

Birds: A Literary Companion, 328-329

Larus argentatus, 78, 85-86, 234

californicus, 211, 234

crassirostris, 11, 234

delawarensis, 211

glaucescens, 78, 85-86

hyperboreus, 85

michahellis, 234

occidentalis, 330-331

schistisagus, 11, 234

Laterallus jamaicensis, 111-121 leucopareia, Branta hutchinsii, 81

Leucophaeus atricilla, 30

Leucosticte tephrocotis, 78, 87-88

Limosa haemastica, 231

lapponica, 5-6, 231

littoralis, Leucosticte tephrocotis, 87

Longspur, Smith's, 33-36

Loon, Arctic, 11, 86, 235

Pacific, 86

Yellow-billed, 11, 30, 235

Lovette, Irby J., see Robinson, B. W.

Loxia curvirostra, 21 leucoptera, 3, 21, 255

Mallard, 28

Marrón, Gerardo, see Carmona, R.

Martin, Purple, 33, 159-163

Matsuoka, Steven M., see Robinson, B. W. maxillaris, Melospiza melodia, 118-119

maxima, Leucosticte tephrocotis, 87

McCaskie, Guy, see Benson, T. A., and see Singer, D. S.

Meadowlark, Eastern, 3, 228, 251-252

Melanitta americana, 29

deglandi, 230

fusca, 230

stejnegeri, 3, 230

Melospiza melodia, 118-119

Melozone aberti, 267

crissalis, 62

fusca, 263-267

fusca $\times$ Pipilo maculatus, 263-267

Meyers, Martin, see Tinsman, J.

Micrathene whitneyi, 16, 245

minima, Branta hutchinsii, 81

Molina, Kathy C., see Shuford, W. D.

Moorhen, Common, 155

Eurasian [= Common] $\times$ Eurasian Coot, 150

Moreno-Higareda, Hiram Rafael, see RuizCampos, G.

Morus bassanus, 22, 143, 255

Motacilla alba, 20, 249

citreola, 3,20

flava, 249

tschutschensis, 249

Murre, Thick-billed, 234

Mycteria americana, 15, 229

Myiarchus cinerascens, 18, 167

crinitus, 18

tuberculifer, 3, 18, 32

Myiodynastes luteiventris, 245 maculatus, 245

Night-Heron, Black-crowned, 190-220

Yellow-crowned, 204 


\section{INDEX}

Nightjar, Buff-collared, 230

nigricans, Branta bernicla, 29

nigrilora, Setophaga pitiayumi, 253

nivalis, Plectrophenax nivalis, 179

Numida meleagris $\times$ Gallus gallus, 151-153

Nuthatch, Brown-headed, 164

European, 164

Pygmy, 164-166

Nyctanassa violacea, 204

Nycticorax nycticorax, 190-220

oberholseri, Toxostoma curvirostre, 249

obsoletus, Rallus obsoletus, 117, 118-119

ocularis, Motacilla alba, 20

Oporornis agilis, 22, 36, 252-253

Oriole, Baltimore, 167

Bullock's, 167, 169, 170

Hooded, 167, 169, 170

Orchard, 21, 36, 167

Scott's, 167

Streak-backed, 255

Osprey, 86

Owl, Barred, 122-128

Cinereous, 122-128, 221-227

Elf, 16, 245

Fulvous, 122-128, 221-227

Northern Pygmy-, 65-67

Spotted, 66

pacifica, Calidris alpina, 83

pallidior, Plectrophenax nivalis, 179

pallidissimus, Larus hyperboreus, 86

Pandion haliaetus, 86

Pandolfino, Edward R., and Ray, Chris,

Comparison of the Songs of Cassin's and Plumbeous Vireos, 293-306

Parabuteo unicinctus, 32

Parakeet, Yellow-chevroned, 228, 254

Parkesia motacilla, 22, 252

Parula, Tropical, 3, 228, 253

Passer montanus, 20

Passerculus sandwichensis, 33

Passerina caerulea, 167

versicolor, 254

Pearman, Myrna, de Groot, Leo, Holroyd, Geoffrey L., and Thunberg, Stephanie, Earlier Spring Arrival of the Mountain Bluebird in Central Alberta, Canada, 47-58

pekinensis, Alauda arvensis, 248

Pelecanus erythrorhynchos, 214

Pelican, American White, 214

Pericoli, Ralph V., Karsten, Emma L., Fish, Allen M., and Briggs, Christopher W., Nesting Biology of Urban Cooper's Hawks in Alameda County, California,
307-317

personata, Sula dactylatra, 129

Petrel, Band-rumped Storm-, 3, 11-13

Black Storm-, 235

Bulwer's/Jouanin's, 235-237

Gray-faced, 14

Herald, 14

Jouanin's, 235

Kermadec, 3, 14

Leach's Storm-, 237

Least Storm-, 235

Murphy's, 14

Providence, 14

Townsend's, 13

Tristram's Storm-, 228, 235

Wedge-rumped Storm-, 13, 235

Peucaea cassinii, 21

Pewee, Eastern Wood-, 19

Greater, 19, 245

Phalacrocorax auritus, 214, 215, 270-292 pelagicus, 78-91

Phoebastria albatrus, 11

Phoebe, Say's, 86

Phylloscopus borealis, 20, 28, 86-87

borealis/examinandus, 19-20

examinandus, 20, 28, 86-87

fuscatus, 19, 255

inornatus, 228

xanthodryas, 20, 28

Pieplow, Nathan, and Spencer, Andrew, Vocal Differences among the Barred, Cinereous, and Fulvous Owls,

122-128; and Spencer, Andrew, Sanchez, Carlos, and Grosselet, Manuel, Changes in the Status and Distribution of the Cinereous and Fulvous Owls in Mexico, 221-227

Pintail, Northern, 82

Pipilo chlorurus, 263-267

chlorurus $\times$ P. maculatus, 263-267

maculatus, 263-267

maculatus $\times$ Melozone fusca, 263-267

ocai, 267

Pipit, Pechora, 20-21

Piranga flava, 36

ludoviciana, 59-64

olivacea, 36

Platalea ajaja, 15, 242

Plectrophenax hyperboreus, 78-80, 88, 174-189

nivalis, 21, 88, 174-189, 249

Plegadis chihi, 156, 242

falcinellus, 15, 242

Plover, Common Ringed, 82-83, 228, 231 


\section{INDEX}

European Golden-, 3, 62, 231

Pacific Golden-, 82

Semipalmated, 83, 231

Pluvialis apricaria, 3, 62, 231

fulva, 82

Podiceps grisegena, 318-319

nigricollis, 194

Poecile atricapillus, 267 gambeli, 267

Porphyrio martinicus, 231

principalis, Corvus corax, 86

Progne subis, 33, 159-163

Pseudobulweria, 235

Pterodroma gouldi, 14

heraldica, 14

neglecta, 3,14

solandri, 14

ultima, 14

ptilocnemis, Calidris ptilocnemis, 78-91

pulchra, Setophaga pitiayumi, 253

purpureus, Haemorhous purpureus, 33

pusillula, Melospiza melodia, 118-119

Pycnonotus jocosus, 228, 254-255

Pygmy-Owl, Northern, 65-67

Pyle, Peter, Molt, Age, and Identification of the Masked and Nazca Boobies in California, 129-149

Quail, California, 65-67

Gambel's, 65

Quiscalus quiscula, 252

Radamaker, Kurt A., Book Review: An Expedition to Ramsey Canyon: The 1896 Field Journal of Ornithologist Harry S. Swarth, 261-262

Rail, Black, 111-121

Ridgway's, 117, 118-119

Rallus obsoletus, 117, 118-119

Raven, Common, 86

Ray, Chris, see Pandolfino, E. R.

Redpoll, Common, 249

Redshank, Spotted, 233

Regulus calendula, 320-324

Reyes Bonilla, Héctor, see Carmona, R.

Rhodostethia rosea, 3, 11, 85

Richardson, Rachel M., see Robinson, B. W.

Rissa brevirostris, 78, 80-81, 85

Rivas, Abigail, see Carmona, R.

Robin, Rufous-backed, 20, 33

Robinson, Bryce W., Withrow, Jack J., Richardson, Rachel M., Matsuoka, Steven M., Gill, Robert E. Jr., Johnson, Andrew S., Lovette, Irby J., Johnson, James A., DeGange, Anthony R., and Romano, Marc D., Further Informa- tion on the Avifauna of St. Matthew and Hall Islands, Bering Sea, Alaska, 78-91

Romano, Marc D., see Robinson, B. W. roselaari, Calidris canutus, 83

Ross, Hayley H., see Bosma, M. D.

Rosy-Finch, Gray-crowned, 78, 87-88

Rottenborn, Stephen C., see Erickson, R. A.

Ruff, 29

Ruiz-Campos, Gorgonio, de León-Girón, Gonzalo, Moreno-Higareda, Hiram Rafael, and Contreras-Balderas, Armando Jesús, Unusual Record of Bonaparte's Gull in the Sierra San Pedro Mártir, Baja California, 325-326 rustica, Hirundo rustica, 104-110 samuelis, Melospiza melodia, 118-119 Sanchez, Carlos, see Pieplow, N.

Sanderling, 330-331

Sandpiper, Buff-breasted, 72-74

Curlew, 231

Marsh, 228, 234

Rock, 78-91

Terek, 83

Upland, 83, 231

Western, 82, 83

White-rumped, 233

Wood, 228, 233-234

Sayornis saya, 86

Scoter, Black, 29

Stejneger's, 3, 230

Velvet, 230

White-winged, 230

Setophaga graciae, 22, 253-254

petechia, 167

pinus, 253

pitiayumi, 3, 228, 253

tigrina, 22, 253

Shearwater, Cory's, 237

Great, 14

Wedge-tailed, 14, 237

Shelduck, Ruddy, 4, 230

Shuford, W. David, Course Review: Learning California Bird Sounds, 4th edition, 157-158; and Kelly, John P., Condeso, T. Emiko, Cooper, Daniel S., Molina, Kathy C., and Jongsomjit, Dennis, Distribution and Abundance of Colonial Herons and Egrets in California, 2009-2012, 190-220; and Molina, Kathy C., Kelly, John P., Condeso, T. Emiko, Cooper, Daniel S., and Jongsomjit, Dennis, Distribution and Abundance of Double-crested 


\section{INDEX}

Cormorants Nesting in the Interior of California, 2009-2012, 270-292

Sialia currucoides, 47-58

Sibirionetta formosa, 230

Sieburth, Desmond E., A Review of Western Bird Records Committee Websites, 68-71

Singer, Daniel S., Benson, Thomas A., McCaskie, Guy, and Stahl, Justyn, The 43rd Annual Report of the California Bird Records Committee: 2017 Records, 2-20

Sitta europaea, 164 pusilla, 164 pygmaea, 164-166

Skylark, Eurasian, 228, 248

smithsonianus, Larus argentatus, 85-86

Snipe, Common, 83

Wilson's, 83

Somateria spectabilis, 4, 230

Sparrow, Cassin's, 21

Eurasian Tree, 20

Field, 21, 249

Golden-crowned, 88

Grasshopper, 36

LeConte's, 21, 249-251

Savannah, 33

Song, 118-119

Spencer, Andrew, see Pieplow, N.

Spinus lawrencei, 33

Spiza americana, 36

Spizella pusilla, 21, 249

Spoonbill, Roseate, 15, 242

Stahl, Justyn T., see Benson, T. A., and see Singer, D. S.

Stercorarius parasiticus, 85

Sterna forsteri, 194, 211

Stint, Little, 10, 233

Red-necked, 8

Stork, Wood, 15, 229

Storm-Petrel, Band-rumped, 3, 11-13

Black, 235

Leach's, 237

Least, 235

Townsend's, 13

Tristram's, 228

Wedge-rumped, 13, 235

Strauss, Emilie, and Swanson, David L., Apparent Use of a Rock Crevice as a Nocturnal Roost by a Ruby-crowned Kinglet, 320-324

Streptoprocne zonaris, 3

Strix fulvescens, 122-128, 221-227

occidentalis, 66 sartorii, 122-128, 221-227

varia, $122-128$

Sturnella magna, 3, 228, 251-252

Sula dactylatra, 14, 129-149, 238-239

dactylatra/granti, 14-15, 131, 229, 240

granti, 14, 129-149, 229, 239-240

sula, 15, 229, 240-241

swainsoni, Vireo gilvus, 59-64

Swallow, Barn, 104-110

Tree, 159

Swan, Bewick's, 78, 81-82

Trumpeter, 29, 230

Tundra, 78, 81-82, 230

Swanson, David L., see Strauss, E.

Swift, White-collared, 3

Tachycineta bicolor, 159

Tadorna ferruginea, 4, 230

Tanager, Hepatic, 36

Scarlet, 36

Western, 59-64

Tarsiger cyanurus, 228, 248-249

taverneri, Branta hutchinsii, 81

Taylor, Daniel M., Winter Populations of Waxwings in Idaho, 92-103

Teal, Baikal, 230

Green-winged, 28, 82

tephrocotis, Leucosticte tephrocotis, 87

Tern, Black, 192, 194, 211

Caspian, 211

Forster's, 194, 211

Thrasher, Curve-billed, 20, 228, 249, 255

Thrush, Gray-cheeked, 20

Wood, 20, 255

Thunberg, Stephanie, see Pearman, M.

Tinsman, Jeanne, and Meyers, Martin, Nevada Bird Records Committee Report for 2018, 27-37

Tønnessen, David, Putative Canyon Towhee $\times$ Spotted Towhee: A New Intergeneric Hybrid, 263-267

Towhee, Abert's, 267

California, 62

Canyon, 263-267

Canyon $\times$ Green-tailed Towhee, 266

Canyon $\times$ Spotted Towhee, 263-267

Collared, 267

Green-tailed, 263-267

Green-tailed $\times$ Canyon Towhee, 266

Green-tailed $\times$ Spotted Towhee, 263-267

Spotted, 263-267

Spotted $\times$ Canyon Towhee, 263-267

townsendi, Plectrophenax nivalis, 179

Toxostoma curvirostre, 20, 228, 249, 255 


\section{INDEX}

traillii, Empidonax traillii, 248

Tringa erythropus, 233

glareola, 228, 233-234

nebularia, 83-84

stagnatilis, 228, 234

Troglodytes hiemalis, 19, 33, 248

pacificus, 33, 248

Turdus rufopalliatus, 20, 33

Tyrannus couchii, 32

crassirostris, 18, 32, 245

forficatus, 32

melancholicus, 32

savana, 18

umbrina, Leucosticte tephrocotis, 78, 87-88

Unitt, Philip, Hargrove, Lori, and Clark, Kevin B., Overlap of Molt and Fall Migration of the Western Tanager and Warbling Vireo in Southern California, 59-64

Uria lomvia, 234

Veery, 249

vegae, Larus argentatus, 78, 85-86

Vermivora chrysoptera, 22, 36, 252

chrysoptera $\times$ V. cyanoptera, 252

cyanoptera, 22, 252

Vireo, Bell's, 62, 167

Blue-headed, 19, 248

Cassin's, 19, 248, 293-306

Hutton's, 19

Plumbeous, 293-306

Warbling, 59-64

White-eyed, 19, 33, 248

Yellow-throated, 23

Vireo bellii, 62, 167

cassinii, 19, 248, 293-306

flavifrons, 23

gilvus, 59-64

griseus, 19, 33, 248

huttoni, 19

plumbeus, 293-306

solitarius, 19, 248

viridigularis, Gavia arctica, 86

vlasowae, Plectrophenax nivalis, 179

Vultur gryphus, 15

Vulture, Black, 15, 242

Turkey, 15

Wagtail, Citrine, 3, 20
Eastern Yellow, 249

Western Yellow, 249

White, 20, 249

Walker-Roseman, Lisa D., Giusti, Kevin

A., and Hayes, Floyd E., Post-Breeding

Extra-Pair Pseudocopulation in the

Pygmy Nuthatch, 164-166

Warbler, Arctic, 20, 28, 86-87

Arctic/Kamchatka Leaf, 19-20

Blue-winged, 22, 252

Blue-winged $\times$ Golden-winged, 252

Cape May, 22, 253

Connecticut, 22, 36, 252-253

Dusky, 19, 255

Golden-winged, 22, 36, 252

Golden-winged $\times$ Blue-winged, 252

Grace's, 22, 253-254

Japanese Leaf, 20, 28

Kamchatka Leaf, 20, 28, 86-87

Kentucky, 3, 36

Mourning, 22, 253, 255

Red-faced, 255

Worm-eating, 22, 252

Yellow, 167

Yellow-browed, 228

Waters, Liam M., see Young, A. R.

Waterthrush, Louisiana, 22, 252

Waxwing, Bohemian, 92-103

Cedar, 92-103

Whistling-Duck, Black-bellied, 4

Fulvous, 229-230

Withrow, Jack J., Plumage Variation in Bering Sea Plectrophenax Buntings and the Specific Status of McKay's Bunting, 174-189; see also Robinson, B. W.

Wood-Pewee, Eastern, 19

Wren, Pacific, 33, 248

Sedge, 19

Winter, 19, 33, 248

Wryneck, Eurasian, 3, 16-18

Xenus cinereus, 83

Yellowthroat, Belding's, 38-46

Young, Austin R., and Waters, Liam M., First Record of the Purple Martin Breeding in Idaho, 159-163

yukonensis, Sayornis saya, 86

Zonotrichia atricapilla, 88 


\section{WESTERN BIRDS}

\section{Quarterly Journal of Western Field Ornithologists www.westernfieldornithologists.org}

President: Jon L. Dunn, 24 Idaho St., Bishop, CA 93514; cerwa@earthlink.net

Vice-President: John Harris, 12806 Lancaster Rd., Oakdale, CA 95361; johnh@mills.edu

Past-President: Kurt M. Leuschner, 70065 Sonora Rd. \#267, Mountain Center, CA 92561; kleuschner@collegeofthedesert.edu

Treasurer/Membership Secretary: Suzanne M. Carota, 3476 Armourdale Ave., Long Beach, CA 90808; smcarota@gmail.com

Recording Secretary: Liga Auzins Wurster, 12842 Safford East, Garden Grove, CA 92840; llauzins@yahoo.com

Directors: Matthew J. Baumann, Wendy Beers, Kimball L. Garrett, Susan S. Gilliland, Homer Hansen, Karen Anderson Havlena, Kristie Nelson, Andrew Mauro, Edward R. Pandolfino, Bryce W. Robinson, Diane Rose, Christopher W. Swarth

Editor: Philip Unitt, San Diego Natural History Museum, P. O. Box 121390, San Diego, CA 92112-1390; birds@sdnhm.org

Assistant Editor: Daniel D. Gibson, P. O. Box 155, Ester, AK 99725; avesalaska@gmail.com

Associate Editors: Kenneth P. Able, Matthew J. Baumann, Daniel S. Cooper, Douglas W. Faulkner, Kimball L. Garrett, Daniel D. Gibson, Robert E. Gill, Daniel R. Ruthrauff, Christopher W. Swarth

Graphics Manager: Virginia P. Johnson, 4637 Del Mar Ave., San Diego, CA 92107; gingerj5@juno.com

Photo Editor: Peter LaTourrette, 1019 Loma Prieta Ct., Los Altos, CA 94024; platourrette@comcast.net

Featured Photo: Ryan Terrill, Moore Laboratory of Zoology, Biology Department, Occidental College, 1600 Campus Rd., Los Angeles, CA 90041

Book Reviews: Catherine Waters, P.O. Box 3505; 25131 Alicia Dr., Dana Point, CA 92629, cpannellwaters@gmail.com

WFO Website: Timothy W. Brittain; webmaster@westernfieldornithologists.org

Membership dues, for individuals and institutions, including subscription to Western Birds: Life, $\$ 800$ (payable in two equal annual installments); Family $\$ 45$; Regular U.S. $\$ 40$ for one year, $\$ 70$ for two years, $\$ 100$ for three years. Dues and contributions are tax-deductible to the extent allowed by law.

Send membership dues, changes of address, correspondence regarding missing issues, and orders for back issues and special publications to the Treasurer. Make checks payable to Western Field Ornithologists.

Back issues of Western Birds within U.S. \$40 per volume, $\$ 10$ for single issues, including shipping and handling. Outside the U.S. \$55 per volume, \$15 for single issues, including shipping and handling. 




Photo by (C) Tony Brake of Richmond, California:

Cooper's Hawk (Accipiter cooperii), Remillard Park, Berkeley, California, 22 June 2004.

Over the past 50 years, the biology of Cooper's Hawk has been revolutionized as the species went from being the persecuted "chicken hawk" to a common urban adapter. In this issue of Western Birds, Ralph V. Pericoli, Emma L. Karsten, Allen M. Fish, and Christopher W. Briggs report their study of Cooper's Hawks nesting in the cities of Berkeley and Albany, California, They found $94 \%$ of nests successful, an average productivity of 3.6 fledglings per nest, and no relationship between these rates and the incidence of trichomoniasis in birds representing potential prey brought to a nearby rehabilitation center. 

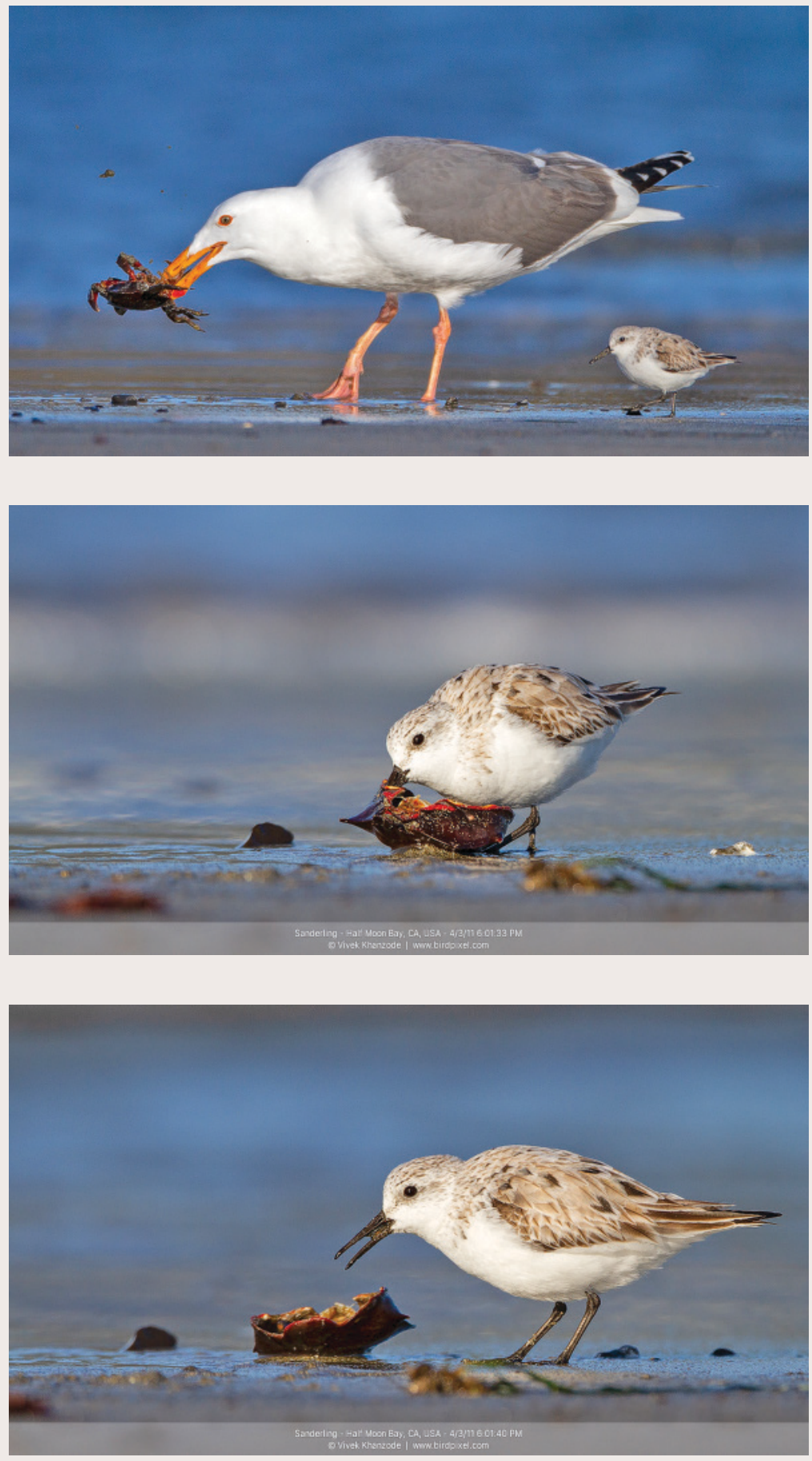

"Featured Photos" by (c) Vivek Khanzode of Sunnyvale, California: a Sanderling (Calidris alba) watching a Western Gull (Larus occidentalis) eating its fill of a crab (Pugettia producta), then scavenging the remains after the gull abandoned them-the first evidence of a Sanderling aware that it can capitalize on a predator's behavior. 